\title{
Medida da atividade da Fosfatase Alcalina de E.coli em pH 11: potencial uso na avaliação da qualidade microbiológica da água de abastecimento
}

Kumie Fujimori

Tese apresentada ao Programa de Pós-Graduação em Saúde Pública para obtenção do título de Doutor em Saúde Pública

Área de concentração: Saúde Ambiental

Orientador: Prof. Dr. José Luiz Negrão Mucci

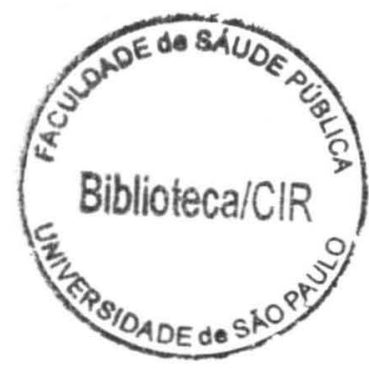

São Paulo

2005 
Autorizo, exclusivamente para fins acadêmicos e científicos, a reprodução total ou parcial desta tese, por processos fotocopiadores.

Assinatura:

Data:

$$
46276 / 2005 \text { doc }
$$


A meus pais (in memorian), Gustavo, Ken e Jo. 


\section{AGRADECIMENTOS:}

Ao Prof. Dr. JOSÉ LUIZ NEGRÃO MUCCI pela orientação prestada na realização deste trabalho.

Ao Prof. Dr. BENY SPIRA, pesquisador do Laboratório de Fisiologia de Microorganismos do Departamento de Microbiologia do Instituto de Ciências Biomédicas da Universidade de São Paulo, meu especial agradecimento pela idéia de utilizar o ensaio de medida da atividade da fosfatase alcalina de $E$. coli como tema de minha tese, além de oferecer gentilmente o seu laboratório assim como os materiais e equipamento, sem os quais teria sido impossível a realização da mesma.

À CIDINHA, MÁRCIA e RENILDA da Comissão de Pós- Graduação da Faculdade de Saúde Pública, pela paciência e compreensão.

\section{À JULIA.}

Ao GUSTAVO, pela confecção das tabelas, figuras e tratamento de dados, assim como pela paciência cotidiana.

Aos meus filhos KEN e JO. 


\section{RESUMO}

Fujimori, K. Medida da atividade da Fosfatase Alcalina de E.coli em pH=11: potencial uso na avaliação da qualidade microbiológica da água de abastecimento. São Paulo; 2005. [Tese de Doutorado-Faculdade de Saúde Pública da USP].

Objetivo. Um dos problemas fundamentais da Saúde Pública consiste na qualidade microbiológica da água de abastecimento. Garantir que a população seja servida por água de boa qualidade depende de diversos aspectos. Um deles fundamenta-se na avaliação da qualidade microbiológica da água para consumo humano. A detecção rápida e eficiente de microorganismos é uma necessidade constante para que medidas adequadas sejam tomadas e que a comunidade abastecida seja protegida. Este estudo tem como objetivo testar a reprodutibilidade de uma condição experimental específica (1M CAPS, $\mathrm{pH}$ 11) que teria potencial para ser utilizada como modelo para o desenvolvimento de novas técnicas na detecção de coliformes fecais na água de abastecimento, de maneira simples, rápida e com baixo custo. Métodos. Ensaios de atividade da fosfatase alcalina da bactéria E.coli foram realizados em tampões diferentes com valores variáveis de $\mathrm{pH}$ utilizando o método colorimétrico Resultados. Os resultados dos ensaios foram reprodutíveis. Os ensaios realizados neste estudo em pH 11 indicaram que esta condição experimental pode levar a atividades enzimáticas maiores do que aquelas descritas na literatura. Conclusões.Os resultados poderiam ser utilizados como ponto de partida para um estudo com o objetivo de se estabelecer uma metodologia enzimática para a determinação imediata de coliformes na água de abastecimento.

Descritores: Fosfatase alcalina, E.coli, qualidade da água 


\section{SUMMARY}

Fujimori, K. Medida da atividade da Fosfatase Alcalina de E.coli em pH=11:potencial uso na avaliação da qualidade microbiológica da água para consumo humano.[E.coli alkalyne phosphatase assay at $\mathrm{pH} 11$ : potencial use in the microbiological evaluation of drinking water quality] São Paulo; 2005. [Tese de Doutorado- Faculdade de Saúde Pública da USP].

Objective. One of the most important problems in Public Health is the drinking water quality. To guarantee its quality depends on multiple aspects. One of them is the microbiological quality. The fast and efficient detection of microorganisms is a permanent need in order to take the appropriate measurements to overcome a potential outbrake. The aim of this study is to evaluate the reproducibility of a specific experimental condition in the alkaline phosphatase assay, that is $1 \mathrm{M}$ CAPS $\mathrm{pH} 11$. Methods. E.coli alkaline phosphatase assay was done in a range of $\mathrm{pH}$ values varying from 8 up to 11 , using a colorimetric method. Results. The results were reproducible. In this study, experiments assayed at $\mathrm{pH} 11$ indicate that in this condition an enhanced activity is observed. Conclusions. The results could be used as a starting point for a further study in order to develop a fast, low cost method to detect fecal coliforms in drinking water.

Descriptors: Alkaline Phosphatase, E.coli, water quality 


\section{ÍNDICE}

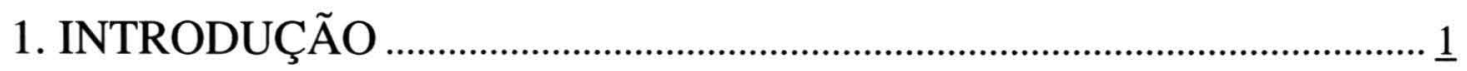

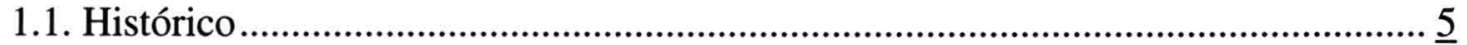

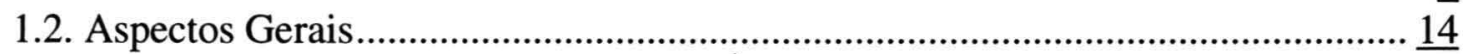

1.3. Etapas do Processo de Tratamento da Água de Abastecimento ........................... $\frac{17}{17}$

1.4. Parâmetros Utilizados na Avaliação da Qualidade Microbiológica da Água ........ 18

1.5. Procedimentos Utilizados na Avaliação da Qualidade Microbiológica da

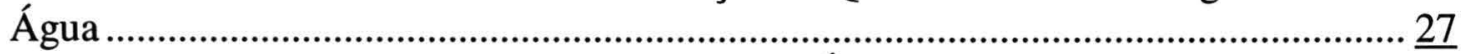

1.6. Biotecnologia e Avaliação da Qualidade da Água............................................ $\underline{38}$

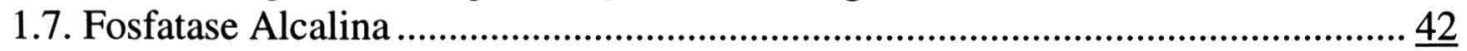

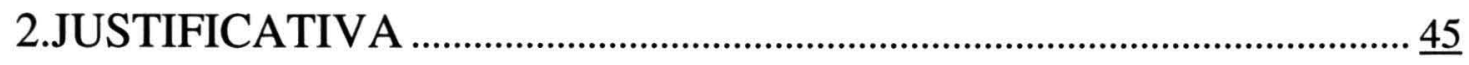

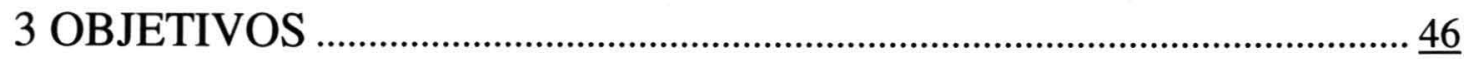

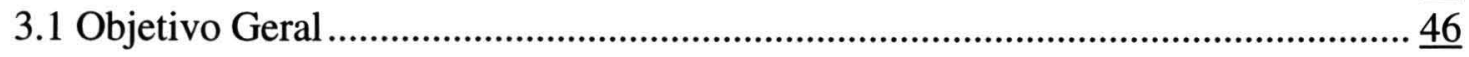

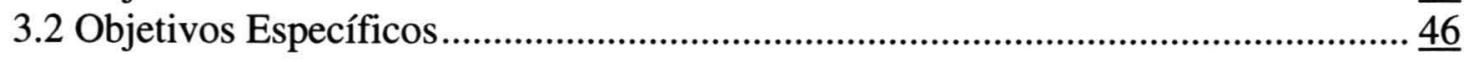

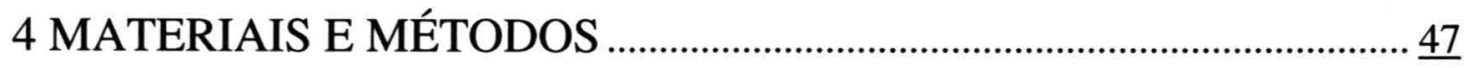

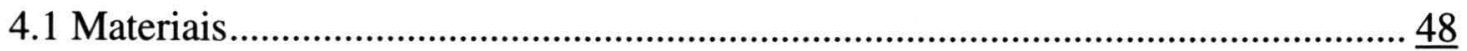

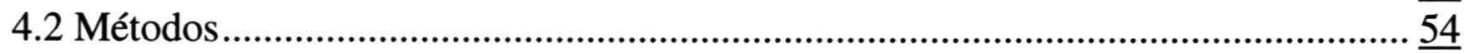

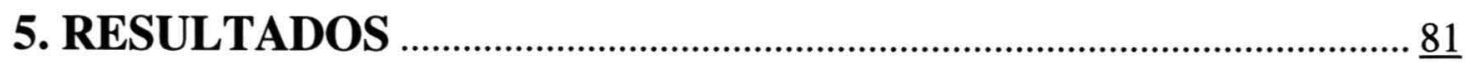

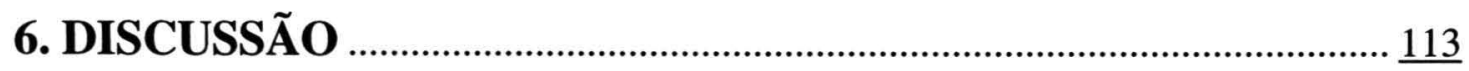

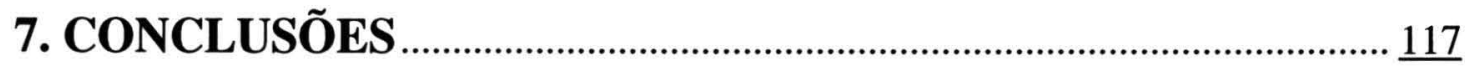

8 CONSIDERAÇÕES FINAIS............................................................. 118

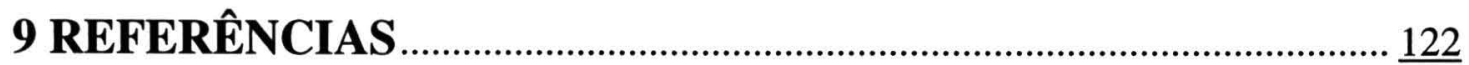




\section{INTRODUÇÃO}

Uma das questões mais importantes e preocupantes que afligem a Humanidade consiste na disponibilidade quantitativa e qualitativa da água de abastecimento.

Apesar da maior parte da superfície terrestre ser recoberta por água (70.8\%), apenas $1 \%$ do volume total de água disponível na superfície terrestre está disponível para consumo humano, cuja população atual é de 6 bilhões.

Os dados mais recentes publicados no documento de agosto de 2004 que avalia o cumprimento das Metas de Desenvolvimento do Milênio, pela Organização Mundial da Saúde e Unicef (WHO e UNICEF 2004), revelam que mais de um bilhão de pessoas têm acesso somente a fontes de água potencialmente perigosas e que mais de $40 \%$ da população mundial não têm acesso ao saneamento básico. Estes números indicam a magnitude da ineqüidade social da Humanidade e do quão distante está a realidade dos ideais proclamados nos artigos da Declaração Universal dos Direitos do Homem (UNITED NATIONS 1948). Apesar disso, a preocupação com a crescente depleção das reservas de água doce mobiliza os diversos setores da sociedade e do conhecimento que se empenham em manter e recuperar a qualidade da água. A primeira conferência das Nações Unidas sobre desenvolvimento e meio ambiente foi realizada em Estocolmo, no ano de 1972 (UNITED NATIONS 1972), quando os assuntos ambientais foram trazidos para o âmbito internacional.

A segunda conferência, realizada em 1992 no Rio de Janeiro, adotou a Agenda 21 (UNITED NATIONS 1992), mas o tema "água” não foi prioritário, pois o aquecimento global e a perda de biodiversidade foram os dois focos principais da reunião. Por outro lado, essa conferência deu indícios de que a Organização das Nações Unidas estaria em um processo de transição no qual os ideais levantados passariam a ser de fato atingidos. O capítulo 16 da Agenda 21 trata especificamente da Biotecnologia aplicada nas questões ambientais. Dentre as várias contribuições da Biotecnologia a melhora no suprimento de água para consumo humano é explicitamente citada, assim como a detoxificação de resíduos perigosos, além de oferecer oportunidades de parcerias globais, principalmente em países em desenvolvimento. 
Já na terceira conferência, da Cúpula Mundial para o Desenvolvimento Sustentável (Rio+10), que aconteceu em Johannesburgo em 2002 (UNITED NATIONS 2002) um retrocesso foi observado, pois a execução dos objetivos colocados pela Agenda 21 novamente cedeu lugar para a colocação e enunciação de ideais, com pouco avanço na prática. A questão da água teve lugar na pauta de discussão, mas houve poucos sinais de vontade política ou passos práticos para o prosseguimento das amplas promessas da Agenda. Além disso, constatou-se que pouco havia sido realizado nos últimos 10 anos. Nesse encontro, a cidade de São Paulo foi citada como um exemplo de megacidade (cidades com mais de 10 milhões de habitantes) de país em desenvolvimento, onde o desperdício de água é de cinco a vinte vezes maior do que em outras cidades.

No encontro Rio+10, o ano de 2003 foi estabelecido como o ano internacional da água, quando comunidades e governos seriam cobrados quanto às práticas de implementação dos acordos realizados na conferência. De acordo com a ONU, para reduzir pela metade o número de pessoas que não têm acesso à água para consumo humano até 2015 são necessários entre U\$ 14 bilhões e U\$ 30 bilhões por ano. A energia foi outra questão polêmica juntamente com a agricultura. Idealmente, os países deverão ter, até a próxima década, pelo menos $10 \%$ de sua matriz energética formada por fontes de energia renováveis. A União Européia quer que boa parte dessa energia renovável venha de grandes hidrelétricas, mas esta questão envolve o problema da água e não está de acordo com a sustentabilidade do ambiente.

Outro importante encontro mundial que ocorreu no ano de 2004 foi o Fórum Barcelona (FÓRUM BARCELONA 2004), criado para refletir, discutir e buscar soluções para os principais conflitos culturais e sociais deste século. A diversidade cultural, o desenvolvimento sustentável e as condições para a paz foram os três eixos temáticos fundamentais. "Diálogos", foi o nome dado ao conjunto de congressos, seminários, debates e apresentações sobre temas de importância estratégica para o poder público, e um deles foi “Água para a vida e para a segurança” (FÓRUM BARCELONA 2004).

A conclusão mais importante desse "Diálogo" foi de que a escassez de água é mais uma questão de má administração do que falta do recurso propriamente dito. 
Torna-se necessária uma nova cultura onde, primeiramente, o uso de água deve ser assegurado como um direito humano inalienável e, em segundo lugar, que em qualquer atividade ela deve ser tratada de maneira ecologicamente sustentável. Mário Soares, ex-presidente de Portugal utilizou o termo "petrolização" da água. Por ser um produto escasso, a água atrai o interesse de empresas que visam o lucro e corre o risco de se tornar gerador de lucros.

Desse "Diálogo", resultou o documento "Princípios Fundamentais para uma concordância global sobre os direitos à água", semelhante à declaração dos direitos universais do homem, mas também com obrigações embutidas, que será apresentado à ONU. De acordo com os princípios contidos no documento, cada indivíduo deve ter acesso à quantidade suficiente de água (de 40 a 50 litros diários, em média), para suprir as necessidades básicas: para beber, para a higiene, para a agricultura e pecuária. Apesar desse volume variar de acordo com a região geográfica e conseqüentemente os hábitos culturais, o direito à qualidade deveria ser o mesmo para todos. $\mathrm{O}$ direito à água também está diretamente ligado às tarifas razoáveis, pois não se trata de um produto gerador de lucros. O manejo sustentável deve ser uma característica essencial para preservar "um balanço harmonioso entre o acesso à água, necessidades de saúde, proteção ambiental, particularmente de ecossistemas aquáticos, e desenvolvimento humano".

A solução para os problemas relativos à água estaria no investimento local, através de microprojetos que aliassem métodos tradicionais aos últimos avanços tecnológicos, com a participação da sociedade civil.

Alguns setores da sociedade têm se mobilizado, na tentativa de manter a qualidade do meio ambiente e da água em particular.

No setor técnico-científico, a Biotecnologia é um instrumento valioso na solução de questões cruciais referentes ao meio ambiente. Neste trabalho apresentam-se algumas possibilidades inovadoras, que somadas às técnicas tradicionais, seriam de grande valia à Saúde Pública e em particular à engenharia sanitária.

A Biotecnologia Ambiental tem como objetivo desenvolver métodos da engenharia sanitária com o uso de microrganismos e seus produtos para a melhora da qualidade ambiental. Os microorganismos são tradicionalmente utilizados no 
tratamento de águas residuárias. A enorme diversidade de microorganismos, cada qual com a sua maquinaria enzimática, torna-os capazes de metabolizar um grande número de compostos orgânicos e inorgânicos.

$\mathrm{O}$ advento da Biotecnologia Molecular tem aberto um leque de oportunidades para a engenharia sanitária, particularmente na utilização dos resultados obtidos a partir da enzimologia. Os desdobramentos do projeto genoma microbiano, iniciado em 1994 (UNITED STATES DEPARTMENT OF ENERGY 1994) serão os projetos genoma funcionais, i.e., os transcriptomas e proteomas. Enquanto o genoma corresponde ao conjunto de todos os genes de uma determinada espécie, o transcriptoma refere-se ao conjunto de todos os RNAs mensageiros transcritos do genoma e o proteoma corresponde a todas proteínas traduzidas.

Futuramente, o acúmulo de conhecimento da estrutura e do funcionamento de substâncias com atividade catalítica produzidas por microorganismos será de grande valia para a conservação e recuperação de recursos naturais.

No guia de bioética desenvolvido em 1999 pela Organização Mundial da Saúde (OMS/WHO) (DAAR 1999) e apresentado na Assembléia da Organização Mundial, o médico Abdullah Daar relator do manual, afirma que a nova era testemunhará uma profunda mudança na saúde pública como conseqüência da revolução genética e que os limites tradicionais existentes entre as diversas áreas do conhecimento estão mudando. Novos paradigmas resultarão da aplicação do conhecimento genético, muitas vezes em combinação com outras disciplinas.

Por outro lado, a rede de Ciência e Saúde Ambiental (SEHN) (SCIENCE AND ENVIRONMENTAL HEALTH NETWORK 1994), um consórcio de organizações ambientais norte-americanas que inclui o Fundo de Defesa Ambiental e a Fundação de Pesquisa Ambiental, sustenta que a Ciência é mal utilizada, no sentido em que todo o conhecimento por ela gerado falhou na proteção ambiental e na saúde humana. A rede tem como proposta o uso da Ciência como instrumento para proteger e restaurar a saúde pública e ambiental. As informações e os conceitos éticos com potencial para provocar mudanças essenciais são identificados e a rede auxilia as comunidades, organizações e governos a desenvolverem e implementarem políticas ambientais. A prática da Ciência deveria visar prioritariamente o interesse público. 
Para SOARES et al (2004), a importância da prática do enfoque integrado entre as condições e os conhecimentos sócio-econômicos e ambientais deixa de ter valor quando os projetos que envolvem impactos estratégicos sobre o meio ambiente, assim como as políticas públicas, deixam de reconhecê-la. Os autores propõem que se faça uma abordagem epistemológica na qual todos os setores da sociedade se reconheçam como co-responsáveis pelas crises ambientais e passem a ter uma ética ambiental comum. A reeducação ambiental que respeite os critérios da interdisciplinaridade científica somada à consideração de diversas maneiras de se tratar a questão ambiental permitiria o real exercício da sustentabilidade e da conservação ambiental. As apresentações referentes à Biotecnologia no sítio da Internet publicadas pelo Ministério do Meio Ambiente (MINISTÉRIO DO MEIO AMBIENTE 2004) e pelo Ministério da Ciência e Tecnologia (MINISTÉRIO DA CIÊNCIA E TECNOLOGIA 2004) deixam claro que o potencial da Biotecnologia é tratado muito mais como enorme gerador de lucros do que um conjunto de tecnologias capazes de melhorar a sociedade e o meio ambiente.

\subsection{Histórico}

De acordo com a teoria de Kant-Laplace, o Sol e todos os planetas incluindo a Terra formaram-se simultaneamente. Partículas e fragmentos de pó de nuvens de gás foram atraídos, formando uma esfera de gás incandescente: o Sol. Outros núcleos satélites, pequenos demais para serem estrelas geraram os planetas, há aproximadamente 4,6 bilhões de anos.

Quando a temperatura da superfície da Terra caiu abaixo do ponto de ebulição da água, esta molécula que já estava presente desde a formação do planeta, mas encerrada no interior das rochas, pôde escapar. $\mathrm{O}$ vapor d'água formou imensas nuvens, que escureceram e esfriaram ainda mais a superfície terrestre. Depois de milhões de anos, a água permaneceu no solo sob forma líquida e a atmosfera se formou.

A composição química da atmosfera na época do surgimento da vida na Terra provavelmente era diferente da atual, que é rica em oxigênio. Aparentemente, o 
oxigênio encontrado na atmosfera atual foi produzido a partir da água, por organismos fotossintetizadores que surgiram mais tarde.

Porém, as propriedades físico-químicas da água já eram exatamente como conhecidas hoje, ainda que o ambiente aquático seja modificado com a presença de vida.

Nas décadas de 1920 e 1930, chegou-se a um consenso de que todas as formas de vida são constituídas pelas mesmas unidades básicas. Oparin, na Rússia e Haldane, na Inglaterra, propuseram paralelamente a hipótese de que estas unidades básicas comuns a todos os seres vivos surgiram, através de sínteses prebióticas. Estas sínteses teriam sido possíveis graças às primitivas condições geológicas e atmosféricas da Terra, iniciando assim o acúmulo de uma grande variedade e quantidade de novas moléculas, ou seja, de uma evolução química que proporcionou o surgimento das células. Em suma, todo o processo evolutivo inicial teria ocorrido na água.

Bilhões de anos mais tarde, as primeiras organizações sociais humanas também se estabeleceram ao redor da água, no período pré-histórico denominado Mesolítico situado aproximadamente entre os anos 10.000 e 6.000 a.C., seguindo a cronologia utilizada por SINGER et al, (1956). Nesse período, a Terra sofreu a última era glacial, adquiriu as características geológicas atualmente conhecidas, formando os vales do rio Nilo, dos rios Tigre e Eufrates na Mesopotâmia, Indo e do Huang He (rio Amarelo) na China.

As condições geológicas favoráveis somadas à aquisição da capacidade de controlar o meio ambiente permitiram ao homem pré-histórico passar a ter um estilo de vida sedentário e realizar a revolução neolítica (agrícola), (HAWKES E WOOLEY 1963).

Há mais de 5000 anos a.C., os homens semi-nômades, que inicialmente viviam à beira do rio Nilo fugindo das inundações e voltando a plantar na lama quando as águas baixavam, foram se organizando socialmente. O ritmo sazonal das águas do rio determinou a distribuição do trabalho. Os primeiros diques foram construídos para que o Nilo não inundasse aldeias na época das cheias e reservatórios eram utilizados para armazenar a água. $\mathrm{Na}$ estiagem, canais partindo dos reservatórios levavam a água represada para os campos cultivados. $\mathrm{O}$ 
desenvolvimento tecnológico da irrigação permitiu o estabelecimento da lavoura e do homem propriamente dito nesta região, onde quase nunca chove (MUMFORD, 1934).

Os valores imobiliários eram determinados pela vazão do rio, e os impostos eram cobrados de acordo com a localização do imóvel em relação ao rio. As primeiras questões legais também se deveram ao rio, pois as disputas quanto ao direito ao uso da água eram constantes. A não retenção da água em estação privada e o não represamento da água corrente faziam parte do código moral. $\mathrm{O}$ rio também foi utilizado como meio de transporte garantindo a distribuição rápida e barata dos produtos produzidos ao longo do mesmo, permitindo rápido crescimento da economia (MUMFORD 1934, SINGER et al. 1956)

Politicamente o rio Nilo levou a centralização de um governo, pois era essencial que o enorme trabalho de construção e manutenção de diques, reservatórios e canais (o mesmo sistema que construiu as pirâmides) perdurasse em toda a extensão do rio de maneira coesa, e que a abundância de um ano pudesse ser armazenada para utilizar em épocas menos abastadas. Evidências que indicam um tipo de vida semelhante foram encontradas no vale do rio Indo e do rio Amarelo (SINGER et al. 1956).

$\mathrm{Na}$ América Central, as ruínas incas atestam que esse povo possuía grande conhecimento de engenharia sanitária. As cidades possuíam sistema de drenagem e suprimento de água. Por outro lado, a distância de fontes externas de água e a ineficiência no transporte para as cidades quéchuas pode ter colaborado para a decadência desse povo.

No livro clássico de ROSEN (1994): "Uma História da Saúde Pública”, o autor mostra que a preocupação da Humanidade com o suprimento de água está presente desde a época pré-histórica.

Os gregos foram os pioneiros no planejamento e desenvolvimento de obras públicas, que além de impulsionarem a economia, permitiram um estilo de vida mais sanitário. Grandes pensadores como Arquimedes, e Eupalino, desenvolveram e aplicaram o conhecimento tecnológico no suprimento de água para as cidades, muitas vezes conduzida de locais distantes, através de aquedutos. Hero, o primeiro engenheiro hidráulico utilizou o princípio do sifão para canalizar a água, substituindo 
o uso de aquedutos. Simultaneamente ao sistema de abastecimento de água de beber, regulamentava-se o sistema de esgotamento e o destino de dejetos. As ruínas atestam o hábito dos gregos se banharem e utilizarem lavatórios com descargas. Muitas torneiras eram instaladas em casas particulares, ainda que a maior parte da população utilizasse a água de poços públicos. As cisternas públicas eram limpas e assim mantidas por escravos, habilitados a garantirem a pureza das águas. Na Alexandria, os cidadãos que possuíam cisternas particulares pagavam taxas à cidade, configurando o surgimento de uma das primeiras companhias públicas da História (MUMFORD, 1934; SINGER et al. 1956;ROSEN, 1994).

O texto hipocrático De Ares, Águas e Lugares reflete a importância dada ao equilíbrio entre o homem e seu ambiente. Até o final do século XIX, essa foi a referência teórica utilizada pela Medicina, na compreensão de doenças endêmicas e epidêmicas.

Porém, foram os romanos que marcaram a História com o seu sistema de suprimento de água. No livro Os aquedutos da cidade de Roma, o comissário de água de Roma, Sexto Julio Frontino relata como era feita a administração desse ramo da Saúde Pública.

A capacidade que os romanos tinham de suprirem as necessidades da população é comparável a muitas cidades atuais. A pureza da água era garantida através do uso de bacias de assentamento no meio e no final do aqueduto, nas quais o sedimento precipitava. Os aquedutos eram separados para diferentes finalidades.

Durante a República, não havia setor permanente responsável pela manutenção dos aquedutos. Mas com Augusto a administração dos serviços públicos de saúde, incluindo o suprimento de água, se organizou em um sistema. Criou-se uma Câmara de Água, uma comissão composta por um curador, de nível consular, e dois assistentes, de nível senatorial. Centenas de escravos serviam à comissão para garantir o suprimento de água.

O sistema de esgoto, construído sob as ruas, era utilizado para eliminar a água de superfície e a dos esgotos. O grande esgoto de Roma, cloaca maxima é ainda hoje utilizado.

Provavelmente, muitos surtos de doenças veiculadas pela água, como o tifo e a disenteria foram evitados devido aos cuidados dispensados ao suprimento de água e 
destino do esgoto. Por outro lado, as melhoras não eram extensivas à toda a população. As instalações higiênicas não chegavam às áreas mais pobres da cidade. As primeiras idéias de que o suprimento público de água era uma das necessidades essenciais da vida civil foram perpetuadas pelo geógrafo Pausânias.

Os romanos escolhiam os locais para a construção de cidades em função do resultado do exame de vísceras de animais que pastavam em regiões escolhidas para o assentamento. Quando a coloração das vísceras estava alterada, considerava-se insalubre também para o homem. A malária já era uma doença familiar aos romanos, assim como a sua relação com os pântanos.

A criação de serviços públicos de saúde em um sistema administrativo eficiente foi uma das grandes contribuições dadas pela cultura romana. Mesmo com a queda do Império, esse sistema continuou a funcionar.

Com o declínio do império romano e a permanência por quase 1000 anos da Idade Média, os conhecimentos de higiene e saneamento ficaram restritos à Igreja. A população da Idade Média, confinada entre altos muros dos feudos sofreu as conseqüências da falta desses conceitos, sendo constantemente assombrada por doenças infecciosas, transmitidas pela água e pela aglomeração.

Para a população medieval, o suprimento de água de beber era feito através de poços. A pureza da água era mantida através de regulamentos e penalidades, tornando-se a base de um código sanitário oficial. A supervisão sanitária era exercida por uma administração ligada à municipalidade.

No Renascimento, a Saúde Pública se desenvolveu da maneira como é conhecida ainda hoje. O surgimento da classe média, a revolução tecnológica, a ciência natural experimental com enfoque matemático na compreensão dos fenômenos naturais propiciaram o ambiente adequado para tal, ainda que dos séculos XVI ao XVIII, o padrão medieval de Saúde Pública tenha permanecido.

Com a mudança na concepção de sociedade trazida pelo Mercantilismo, assim como o desenvolvimento da teoria matemática da probabilidade, os métodos estatísticos passaram a ser aplicados na análise dos problemas de saúde da população.

No século XVII, as cidades crescentes enfrentavam grande problema de suprimento de água. Em 1609, a Corporação da Cidade transferiu para um cidadão os 
poderes obtidos e a água foi trazida a Londres por uma empresa privada. Outros empreendimentos particulares executaram funções públicas, mudando o perfil dos serviços comunitários. Essas companhias surgiram ligadas às inovações técnicas como o uso de bombas utilizadas no suprimento de água. Aos poucos, maior número de moradias passou a receber água canalizada, porém poluída. A purificação da água através da filtração começou a ser praticada no século XVII.

No Iluminismo, surgiu o conceito de qualidade de vida e o saneamento e suprimento de água voltou a ter peso na Saúde Pública. O crescimento urbano demandava investimentos no suprimento de água e esgotos. A filtração arenosa da água de abastecimento foi introduzida na companhia de águas de Londres e os Estados Unidos seguiram o modelo britânico. Apesar do pioneirismo inglês, havia um descompasso entre a tecnologia aplicada no suprimento de água e aquela utilizada no esgotamento de refugos. Mesmo quando a água corrente começou a ser utilizada para carrear os excrementos, o problema persistiu. $\mathrm{Na}$ verdade, novos problemas decorrentes dadas fossas cheias e infiltração pelo solo surgiram. Fontes e poços foram poluídos e canais de esgotamento carrearam a água da chuva contaminada com excretas para rios e lagos, que se transformaram em esgotos a céu aberto, tornando-se um dos grandes desafios ambientais do século XIX.

No século XIX, com a crescente industrialização, receberam atenção os problemas urbanos, onde a população trabalhadora vivia amontoada sem abastecimento de água, drenagem, limpeza de ruas e casas nem sistema de esgotos e tampouco escoamento dos refugos. Neste período, houve uma importante reorientação do problema de saúde pública, que passou a ser considerado um problema mais de Engenharia do que de Medicina. Em 1842, foi elaborado o Relatório ou uma Investigação sobre as condições sanitárias da população trabalhadora da Grã-Bretanha, na qual se indicou que as doenças eram consequiência da negligência de medidas administrativas adequadas. Se por um lado houve um lento progresso no controle do ambiente de moradia e de trabalho, esse foi um século marcado por grandes epidemias. Além da cólera na Europa e da febre amarela nos Estados Unidos, a varíola, o tifo exantemático, o tifo, a disenteria, a difteria e a escarlatina surgiam periodicamente na forma de surtos importantes. Com o surgimento da via férrea e do navio a vapor, a comunicação entre locais distantes 
passou a se intensificar e doenças foram importadas. Nesse período, dominavam duas teorias para explicar as doenças infecciosas: a teoria miasmática e a teoria contagionista. A primeira sustentava que as condições sanitárias inadequadas criavam um estado atmosférico que favorecia o surgimento de doenças. A visão contagionista afirmava que os contágios específicos eram as únicas causas de infecções e de doenças epidêmicas, nas quais o agente responsável era um organismo vivo capaz de se reproduzir, assim aqueles que seguiam esta teoria defendiam a quarentena para produtos e indivíduos. As comunidades comerciais relutavam em aceitar esta teoria, pois a quarentena atrasava a circulação de mercadorias e causava prejuízo à economia.

Somente no final do século XIX, com o desenvolvimento da Bacteriologia, e a demonstração de que microorganismos específicos são responsáveis pelas doenças, foi possível entender e concordar quanto à origem e à transmissão de doenças infecciosas. Finalmente, a hipótese levantada pelo epidemiologista inglês John Snow de que o transmissor do cólera seria um organismo vivo específico provindo de excreções de indivíduos enfermos que contaminaram alimentos e águas ou através de mãos sujas, teve comprovação científica. Snow foi o primeiro a utilizar a cloração como método de desinfecção da água durante essa epidemia. A cloração contínua da água de abastecimento foi adotada com sucesso na Inglaterra no início do século XX, onde se observou uma grande redução nas mortes causadas por febre tifóide. Em 1908, a desinfecção foi adotada na cidade de Jersey nos Estados Unidos.

As idéias de que todas as comunidades são de alguma maneira interdependentes e que a comunidade internacional deve prestar assistência social e econômica aos membros mais carentes para solucionar problemas de saúde fizeram com que fosse criada a primeira organização internacional de saúde: o Escritório Panamericano da Saúde, em 1902. Em 1946, criou-se a Organização Mundial da Saúde (WHO- WORLD HEALTH ORGANIZATION). Geraldo de Paula Souza, que em 1925 fez aprovar em São Paulo a obrigatoriedade da cloração da água de abastecimento, participou da proposta de criação dessa organização (CLOROSUR 2004). A OMS ainda hoje é a agência oficial de coordenação mundial no campo da saúde internacional e reconhece que a saúde é "um dos direitos fundamentais de todo 
ser humano, sem distinção de raça, religião, crença política, condição social ou econômica”, como estabelecido na Declaração Universal dos Direitos Humanos.

ROSEN (1994) encerra o seu livro afirmando que "muitos problemas de saúde encontram solução na teoria e esse conhecimento aguarda a aplicação na prática".

Esse livro foi publicado em 1958, somente cinco anos após a estrutura da molécula de DNA ter sido determinada por WATSON E CRICK (1953). Os autores desse trabalho, tampouco Rosen teriam nessa época a menor idéia do impacto que o desenvolvimento Biologia Molecular viria a dar algumas décadas mais tarde para todas as áreas do conhecimento, e em particular, da Saúde Pública. A Biologia Molecular não deixa de ser um desdobramento da revolução bacteriológica, e a evolução concomitante e integrada de várias disciplinas como a Bioquímica, Virologia, Parasitologia, Imunologia, Biologia Estrutural e Ecologia constituem uma nova revolução científica. Os diversos programas de sequenciamento de genomas de inúmeras espécies resultarão em breve em uma enorme coleção de dados. O objetivo final é que o conhecimento resultante dos mecanismos biológicos básicos seja utilizado na resolução de problemas de saúde pública.

No início do século XIX, enquanto se discutia a origem das doenças na Europa, na cidade de São Paulo o fornecimento de água era feito como na Europa do século XV: através de bicas e chafarizes. Na década de 1870, quando a relação entre micróbios e doença estava sendo elucidada por investigadores como Pasteur, em São Paulo os assuntos referentes ao abastecimento atingiram o clamor público e foi criada a Companhia Cantareira de Água e Esgotos. Foi construído o Reservatório da Consolação, o primeiro da cidade e em 1882 , as residências passaram a receber as ligações de água.

No final do século XIX, com o amento da população e a insuficiência da Companhia Cantareira, o governo assumiu o encargo criando a Repartição de Água e Esgotos (RAE), que realizou obras de captação, armazenagem e distribuição de água. Em 1924, houve uma nova crise no abastecimento de água na cidade de São Paulo, mas somente 30 anos depois foi criado o Departamento de Águas e Esgotos (DAE), uma autarquia responsável pelos municípios da região metropolitana. Com a 
alteração institucional no abastecimento de água, criou-se a Companhia Metropolitana de Água de São Paulo, uma empresa de economia mista.

Apesar do aumento da população urbana no Brasil entre as décadas de $1960 \mathrm{e}$ 1970, apenas $12,6 \%$ dos habitantes contavam com serviços públicos de abastecimento de água e 6,4\%dispunham de sistemas de esgotamento sanitário. Até então, a responsabilidade pelos serviços era municipal e conseqüentemente, não havia homogeneidade nas estruturas administrativas e financeiras, resultando na insuficiência de serviços. Além disso, não havia instituições que coordenassem os planejamento e recursos financeiros para suprir as necessidades oriundas do aumento populacional. Para resolver essas questões foi implementado o Sistema nacional de Saneamento no início da década de 1970, integrado pelo Plano Nacional de Saneamento (Planasa), Banco Nacional da Habitação (BNH) e pelo Fundo de Garantia do Tempo de Serviço (FGTS).

Em 1970 foi criada a Companhia Metropolitana de Saneamento de São Paulo - responsável por interceptar, tratar e proceder à disposição final dos esgotos da cidade de São Paulo, assim como o Fomento Estadual de Saneamento Básico (FESB). Três anos mais tarde, as empresas e autarquias de abastecimento de água e coleta de esgotos foram fundidas em uma única empresa, a Sabesp, que passou a ser responsável pela implementação do Plano Nacional de Saneamento, estabelecido pelo Governo Federal, no início da década de 1970.

Atualmente, a Sabesp é uma empresa de economia mista, que tem como principal acionista o Governo do Estado de São Paulo e atua como concessionária dos serviços sanitários municipais. (SABESP 2004)

Para ROSEN (1994): "Em seus estudos, o historiador da Saúde Pública deve levar em conta dois componentes: um, o desenvolvimento da ciência e da tecnologia médicas, pois o entendimento da natureza e da causa da doença fornece o solo para a ação e o controle preventivos. Dois, uma variedade de elementos não científicos em essência, os fatores políticos, econômicos e sociais que determinam a aplicação efetiva do conhecimento resultante do primeiro componente.

A História mostra que os usos da água podem ser múltiplos. Além de ter provavelmente originado a vida na Terra, ser objeto de estudo de muitas áreas do conhecimento, a água ainda hoje é um poderoso instrumento de manipulação 
política, tendo como um dos exemplos o poder exercido por Israel sobre os palestinos da Cisjordânia através da cassação do direito ao uso da água (CESR 2003), o que não deixa de ser um problema de Saúde Pública.

O futuro da Humanidade dependerá em grande parte do manejo da água.

\subsection{Aspectos Gerais}

As características físicas, químicas e microbiológicas de uma amostra de água determinam a sua qualidade e a sua adequação para um uso específico (AMARAL E SILVA, 2001).

A água absolutamente pura, totalmente isenta de resíduos de materiais, raramente é encontrada na Natureza. Em geral, encontram-se sais dissolvidos provenientes de minerais, partículas em suspensão e seres vivos, muitas vezes microscópicos (AMERICAN WATERWORKS ASSOCIATION, 1999).

A potabilidade da água é garantida não só por fontes de boa qualidade, mas também através de técnicas de tratamento para seguir os parâmetros determinados por lei e eliminação de poluentes.

De acordo com o glossário de termos ambientais publicado pela Agência de Proteção Ambiental dos Estados Unidos (U.S. Environmental Protection AgencyUSEPA ou EPA, 2004), o termo poluição é definido genericamente como a presença de uma substância (ou mais) no meio ambiente que, por causa da sua composição química ou quantidade, impede o funcionamento de processos naturais e produz efeitos nocivos sobre a saúde e o meio ambiente. Já o contaminante é definido como qualquer agente físico, químico, biológico ou radiológico na água. A Sabesp define a poluição de maneira análoga, mas a contaminação é definida como a introdução de substâncias nocivas à saúde (SABESP, 2004).

Na década de 1970, tendo em vista a crescente poluição das águas, foi promulgada a emenda das leis federais de controle da poluição que estabelecia a estrutura legal básica que regulava a descarga de poluentes nas águas norteamericanas e tornou-se conhecida como o Ato da Água Limpa (Clean Water Act) (U.S.A. 1977). De acordo com essa lei, o termo poluição foi definido como sendo a 
alteracão da integridade física, biológica, química e radiológica da água e de outros meios.

A principal lei que governa a segurança da água de abastecimento norteamericana é o Ato da Água de Abastecimento (Drinking Water Act), que autoriza a EPA a estabelecer os regulamentos (U.S.A., 1974).

No Brasil, os instrumentos legais mais atualizados são estabelecidos pela Portaria N..$^{\circ}$ 518, de março de 2004 (Brasil, 2004), na qual os procedimentos e responsabilidades relativos ao controle e vigilância da qualidade da água para consumo humano e seu padrão de potabilidade estão especificados. Por este motivo, as definições adotadas neste trabalho são as mesmas descritas no capítulo II Artigo $4^{\circ}$ da Portaria, transcritas a seguir.

I. água potável - água para consumo humano cujos parâmetros microbiológicos, físicos, químicos e radioativos atendam ao padrão de potabilidade e que não ofereça riscos à saúde;

II. sistema de abastecimento de água potável - instalação composta por conjunto de obras civis, materiais e equipamentos, destinada à produção e à distribuição canalizada de água potável para populações, sob a responsabilidade do poder público, mesmo que administrada em regime de concessão ou permissão;

III. solução alternativa de abastecimento de água potável - toda modalidade de abastecimento coletivo de água distinta do sistema de abastecimento de água, incluindo, entre outras, fonte, poço comunitário, distribuição por veículo transportador, instalações condominiais horizontais e verticais;

IV. controle da qualidade da água para consumo humano - conjunto de atividades exercidas de forma contínua pelo(s) responsável(is) pela operação de sistema ou solução alternativa de abastecimento de água, destinadas a verificar se a água fornecida à população é potável, assegurando a manutenção desta condição;

V. vigilância da qualidade da água para consumo humano - conjunto de ações adotadas continuamente pela autoridade de saúde pública, para verificar se a água consumida pela população atende à esta Norma e para avaliar os riscos que os sistemas e as soluções alternativas de abastecimento de água representam para a saúde humana; 
VI. coliformes totais (bactérias do grupo coliforme) - bacilos gram-negativos, aeróbios ou anaeróbios facultativos, não formadores de esporos, oxidase-negativos, capazes de desenvolver na presença de sais biliares ou agentes tensoativos que fermentam a lactose com produção de ácido, gás e aldeído a $35,0 \pm 0,5^{\circ} \mathrm{C}$ em $24-48$ horas, e que podem apresentar atividade da enzima B-galactosidase. A maioria das bactérias do grupo coliforme pertence aos gêneros Escherichia, Citrobacter, Klebsiella e Enterobacter, embora vários outros gêneros e espécies pertençam a este grupo;

VII. coliformes termotolerantes - subgrupo das bactérias do grupo coliforme que fermentam a lactose a $44,5 \pm 0,2{ }^{\circ} \mathrm{C}$ em 24 horas; tendo como principal representante a Escherichia coli, de origem exclusivamente fecal;

VIII. Escherichia Coli - bactéria do grupo coliforme que fermenta a lactose e manitol, com produção de ácido e gás a $44,5 \pm 0,2{ }^{\circ} \mathrm{C}$ em 24 horas, produz indol a partir do triptofano, oxidase negativa, não hidroliza a uréia e apresenta atividade das enzimas B-galactosidase e B-glucoronidase, sendo considerada o mais específico indicador de contaminação fecal recente e de eventual presença de organismos patogênicos;

IX. contagem de bactérias heterotróficas - determinação da densidade de bactérias que são capazes de produzir unidades formadoras de colônias (UFC), na presença de compostos orgânicos contidos em meio de cultura apropriada, sob condições pré-estabelecidas de incubação: $35,0, \pm 0,5^{\circ} \mathrm{C}$ por 48 horas;

O capítulo IV, Artigo 11, refere-se aos padrões microbiológicos de potabilidade: na água destinada para consumo humano e na água tratada no sistema de distribuição (reservatório e rede), a Escherichia coli (esta deve ser preferencialmente adotada) ou os coliformes termotolerantes são utilizados como parâmetro e devem estar ausentes num volume de $100 \mathrm{~mL}$.

O capítulo IV, Artigo 17 normatiza que os métodos analíticos para determinação dos parâmetros físicos, químicos, microbiológicos e de radioatividade devem atender às especificações das normas nacionais que disciplinem a matéria, da edição mais recente da publicação Standard Methods for the Examination of Water and Wastewater, de autoria das instituições American Public Health Association (APHA), American Water Works Association (AWWA) e Water Environment 
Federation (WEF), ou das normas publicadas pela ISO (International Standartization Organization).

\subsection{Etapas do Processo de Tratamento da Água Abastecimento}

O processo de tratamento de água passa por diversas etapas. A primeira delas consiste na captação a partir dos mananciais. A boa qualidade da água na sua origem é um dos aspectos mais importantes para conferir segurança na água de abastecimento (AWWA, 1999).

Impedir que haja contato com resíduos e esgotos é uma medida fundamental para evitar o surto de doenças em uma população. Freqüentemente, a construção de represas causa impactos ambientais tais como o desmatamento e conseqüente erosão e assoreamento. A ocupação desordenada de áreas próximas aos mananciais, sem a infra-estrutura sanitária, compromete a qualidade da água dos reservatórios. O lançamento de esgoto doméstico na água diminui a qualidade da água bruta e aumenta o custo do processo de tratamento. Além do risco aumentado de veiculação de doenças, o excesso de nutrientes como o nitrogênio e o fósforo, causa floração de algas, que compromete a qualidade da água, deixando-a fora dos padrões de potabilidade.

Nas estações de tratamento de água, a água bruta bombeada dos mananciais, passa pelas etapas de desinfecção, coagulação, floculação, decantação, filtração, correção de pH e fluoretação. Na desinfecção, adiciona-se cloro, sulfato de alumínio e cal. O cloro, agente desinfetante propriamente dito é adicionado nessa fase e mantido durante todo o processo. O sulfato de alumínio é utilizado para coagulação e a cal é adicionada a fim de se corrigir o pH (SABESP, 2005)

No próximo passo, os coágulos formados são agregados em floculadores. As partículas grandes assim formadas tornam-se pesadas e precipitam durante a decantação formando lodo. Em seguida, as partículas que não foram removidas por decantação são retidas no processo de filtração, e nova adição de cal e cloro é realizada nesta fase. O flúor também é adicionado. A água tratada é armazenada em reservatório dentro da estação de tratamento de água, posteriormente enviada para 
outros reservatórios localizados em diversas regiões da cidade, e finalmente distribuída para a população.

\subsection{Parâmetros Utilizados na Avaliação da Qualidade Microbiológica da Água}

\subsubsection{Parâmetros Físicos}

A cor, a turbidez, o sabor, o odor e as concentrações de sólidos são parâmetros utilizados na caracterização física da água de abastecimento (PIVELLI, 1998).

A cor de uma amostra de água está associada à redução que a intensidade da luz sofre ao atravessá-la devido à presença de íons metálicos (como o ferro e o manganês), matéria orgânica e/ou efluentes industriais.

A cor é classificada como parâmetro secundário por não necessariamente apresentar risco à população, mas é considerada como padrão de potabilidade (APHA, 1998).

Em estações de tratamento de água, a cor é um parâmetro fundamental por ser uma referência operacional para o controle da qualidade nas diversas etapas do tratamento da água bruta até a filtrada.

A turbidez também refere-se à redução de intensidade que um feixe de luz sofre ao atravessar uma amostra de água, porém não só por absorção mas também por espalhamento, devido aos sólidos em suspensão (APHA, 1998). Atualmente a Portaria 518 de 2004 determina que o padrão de potabilidade é de 5,0 UT qualquer que seja a técnica utilizada (BRASIL, 2004).

A turbidez é um parâmetro operacional bastante importante em várias etapas de tratamento, principalmente nas águas desinfectadas por cloro, também considerado na avaliação da qualidade microbiológica da água (APHA, 1998).

As propriedades organolépticas sabor e odor são parâmetros que determinam a potabilidade da água, mas os limites de aceitação legal são subjetivos por serem referidos simplesmente como "não objetáveis", de acordo com a Portaria 518 de 2004. (BRASIL, 2004). O excesso de matéria orgânica e consequente eutrofização 
conferem sabor e odor à água. Os clorofenóis, resultantes da reação entre fenol e cloro da água de abastecimento, os metais, acidez ou alcalinidade excessivos e cloretos também conferem sabor à água.

\subsubsection{Parâmetros Químicos}

$\mathrm{O}$ pH; a dureza das águas; a presença de compostos químicos inorgânicos e orgânicos; agrotóxicos; cianotoxinas, desinfetantes e os produtos secundários da desinfecção constituem o grupo de parâmetros químicos que determinam a potabilidade da água de abastecimento. Na Portaria 518 /2004 (BRASIL, 2004) estão indicados os valores máximos permitidos para substâncias químicas que apresentam risco à saúde.

Os metais alumínio, ferro, manganês, sódio, zinco, a amônia, os ânions cloreto e sulfato, sulfeto de hidrogênio, compostos orgânicos etilbenzeno e monoclorobenzeno, tolueno, xileno e das substâncias surfactantes formam o grupo de parâmetros secundários (Portaria 518/2004).

Pelo fato de muitos parâmetros químicos estarem intimamente relacionados com os parâmetros físicos, na publicação utilizada como referência, Standard Methods for the Examination of Water and Wastewater (APHA, 1998), não existe uma divisão específica entre os parâmetros físicos e químicos.

$\mathrm{O}$ termo $\mathrm{pH}$ refere-se à concentração de íons hidrogênio, reativos em solução aquosa. A determinação do $\mathrm{pH}$ é fundamental nos processos de tratamento de águas, cujas etapas dependem desse parâmetro e é um padrão de potabilidade da água.

Associados ao conceito de $\mathrm{pH}$, estão os parâmetros de acidez e alcalinidade. As principais fontes de acidez nas águas são os ácidos fracos orgânicos (como o acético) e inorgânicos (como ácido carbônico), os ácidos minerais como o clorídrico, sulfúrico, nítrico e sais ácidos. A alcalinidade da água é dada pelos sais do ácido carbônico (carbonatos e bicarbonatos) e hidróxidos. Uma vez que tanto a acidez quanto a alcalinidade não representam risco potencial à saúde pública, não são parâmetros de potabilidade.

A dureza das águas é definida como a medida da capacidade de precipitar sabão devido à presença principalmente de bicarbonatos de cálcio e magnésio e 
sulfatos de cálcio e magnésio. A interação desses sais com o sabão forma complexos insolúveis. De acordo com a portaria 518/ 2004 (BRASIL 2004) a concentração máxima permitida é de $500 \mathrm{mg} / \mathrm{L}$ de carbonato de cálcio.

As substâncias inorgânicas nocivas incluídas na legislação brasileira mais recente são: o antimônio; arsênio; bário; cádmio; chumbo; cobre; cromo; mercúrio, nitrato e nitrito (como $\mathrm{N}$ ) e selênio. Muitos desses metais surgem nas águas naturais através das descargas de efluentes industriais. A presença de poluentes químicos pode inviabilizar alguns sistemas públicos de água por serem de difícil remoção e o custo da mesma é extremamente elevado. Devido à toxicidade, os metais acima citados são também padrões de emissão de esgotos e de classificação de águas naturais. Os metais, muitos deles mutagênicos, acumulam-se ao longo da cadeia alimentar.

O alumínio, o ferro, o manganês, o sódio e o zinco são metais que, apesar de não serem tóxicos, são parâmetros analisados para determinar a qualidade da água para consumo humano, principalmente por alterarem as propriedades organolépticas da água (PIVELLI 1998).

A presença de zinco deve ser analisada com cuidado, pois muitas vezes, junto com esse metal pode-se encontrar o cádmio, e o chumbo como impurezas do zinco utilizado em galvanizações.

Os ânions sulfato, cloreto e cianeto são parâmetros de potabilidade da água. As principais fontes desses íons em águas superficiais são as descargas de esgoto doméstico e os efluentes industriais

O cloreto e o fluoreto recebem atenção especial pelo fato das adições de cloro e flúor serem obrigatórias na água de abastecimento. A Resolução conjunta SS/SMA (Secretaria da Saúde/ Secretaria do Meio Ambiente) nº 1 de 1997 dispõe sobre o teor mínimo de cloro residual livre na rede de abastecimento de água, que deve ser de 0,2 $\mathrm{mg} / \mathrm{L}$ em qualquer ponto da rede de distribuição e o valor máximo permitido de cloro livre é de $5 \mathrm{mg} / \mathrm{L}$. A Lei 6050 de 1974 e a portaria 635/Bsb de 1975 dispõem sobre a fluoretação da água. No Estado de São Paulo, a concentração ideal de íon fluoreto é de $0,7 \mathrm{mg} / \mathrm{L}$, mas concentrações entre $0,6 \mathrm{mg} / \mathrm{L}$ e $0,8 \mathrm{mg} / \mathrm{L}$ são consideradas potáveis. A concentração máxima permitida para o fluoreto é de $1,5 \mathrm{mg} / \mathrm{L}$. O excesso de flúor na água pode provocar fluorose dentária e outros problemas como uma 
possível descalcificação de ossos em idosos. Por esse motivo, o fluoreto, os desinfetantes e os produtos secundários da desinfecção, estes últimos carcinogênicos potentes, também estão incluídos na tabela de substâncias nocivas. Outras substâncias orgânicas derivadas do petróleo, os agrotóxicos e as cianotoxinas também fazem parte da tabela.

Uma das questões ambientais e legislativas mais preocupantes refere-se ao aumento anual de novas espécies de substâncias lançadas nos corpos d'água. Esses poluentes emergentes, denominados PPCPs (pharmaceutical and personal care pollutants)- poluentes farmacêuticos e de cuidados pessoais(EPA, 2004), formam uma nova categoria de poluentes da qual fazem parte drogas (lícitas e ilícitas), cosméticos, aditivos, conservantes, corantes, hormônios sintéticos (dentre eles os anticoncepcionais), antidepressivos, material radioativo $\mathrm{e}$ outros produtos maciçamente consumidos, metabolizados, excretados pelo menos em parte ainda na forma ativa e lançados no meio ambiente. Provenientes da nova geração de compostos orgânicos, muitas dessas substâncias nunca existiram na Natureza, mas devido às suas bioatividades, acabam se integrando à teia alimentar, acumulam-se $\mathrm{e}$ podem causar efeitos por enquanto desconhecidos pela Ciência.

A observação de que muitos agrotóxicos atuam como disruptores hormonais (i.e. atuam como agentes miméticos alterando o equilíbrio hormonal humano e de animais) foi feita há algumas décadas, mas os investimentos voltados ao estudo dos efeitos ambientais e biológicos dos mesmos estão apenas começando (HUTCHINSON et al. 2000). Apesar de concentrações extremamente baixas terem sido detectadas em alguns rios norte-americanos e canadenses que recebem descargas de esgoto doméstico (da ordem de nano ou picomolar), o problema da bioacumulação deve ser considerado. As formas atuais de tratamento de esgoto não inativam os PPCPs, assim como não há padronização para a detecção dos mesmos. Não há regulamentação para o descarte desse grupo de produtos.

Certamente, cabe às autoridades e à academia focar atenção a esse novo problema e acompanhar a sua evolução, pois esse pode se tornar o grande problema deste século. Uma das questões mais complexas refere-se às conseqüências das interações entre os diferentes compostos aquáticos e deles com os organismos e a conseqüente metabolização. 
A presença de antibióticos também é um motivo de grande preocupação, uma vez que já se observam inúmeras linhagens de bactérias que se tornaram resistentes aos antibióticos tradicionais e a sua presença no meio aquático exerce uma enorme pressão seletiva onde microorganismos cada vez mais adaptados sobreviverão a um amplo espectro de drogas e terão a virulência potencializada pelos poluentes. Os disruptores podem ser os responsáveis pela aparição de deformidades observadas em animais selvagens, reversão sexual em espécies de peixes que normalmente não apresentam esse processo e a diminuição da fertilidade em humanos, além de câncer e outras doenças.

Até o momento, a única recomendação feita pela American Water Works Association (AMERICAN WATER WORKS ASSOCIATION 1999), uma sociedade internacional criada em 1881, sem fins lucrativos e dedicada à melhora da qualidade da água de abastecimento, é de que as drogas não sejam descartadas através do esgoto.

Pesquisas realizadas pela U.S. Geological Survey (Agência de inspeção geológica dos Estados Unidos) entre os anos de 1999 e 2000 em águas superficiais de todo o território norte-americano revelou que a presença de cafeína, esteróides e drogas vendidas sem prescrição médica são as mais comuns (U.S. DEPT. OF INTERIOR, 2000). Os resultados vão de encontro com os resultados de pesquisas realizadas na União Européia e no Canadá. Foram encontrados antibióticos e bactericidas, além de anticoncepcionais e suplementos hormonais. De 95 tipos de substâncias químicas, 81 não eram regulamentadas. Os testes para detecção de compostos químicos têm o elevado custo de 1500 dólares americanos por componente.

Devido à crescente adição de compostos no ambiente aquático, a Agência de Proteção ambiental criou em 1997, uma lista prévia de contaminates que seriam candidatos à regulamentação. Desde o ano de 2001 e a cada cinco anos, a EPA seleciona dentre os candidatos, pelo menos cinco substâncias que se tornarão parâmetro de potabilidade (EPA, 2004). Para isso, são necessários dados suficientes que comprovem seus efeitos adversos, sua ocorrência ou probabilidade de ocorrência em sistemas públicos de abastecimento de água com a freqüência e a intensidade determinada como risco à saúde pública, e que a regulamentação do contaminante 
represente uma oportunidade significativa de redução do risco às pessoas servidas pelo sistema público de abastecimento. Resumindo, a avaliação, comunicação e gerenciamento de riscos ambientais devem ser muito bem conduzidos no processo decisório de inclusão do composto. Uma vez que os pré-requisitos tenham sido preenchidos, mesmo substâncias que não fizeram parte da lista preliminar podem se tornar parâmetro de potabilidade.

\subsubsection{Parâmetros Microbiológicos}

A prevenção e o controle de doenças veiculadas pela água é um dos desafios para a Saúde Pública. A maior consequiência do fato de que mais de um bilhão de pessoas têm acesso somente a fontes de água potencialmente perigosas e que mais de $40 \%$ da população mundial não têm acesso ao saneamento básico (UNICEF e WHO 2004), é o número de 4000 óbitos por dia (UNICEF 2004) de crianças com menos de cinco anos, vítimas de diarréia.

Por outro lado, mesmo os países desenvolvidos, que realizam tratamento de toda água destinada ao consumo humano, possuem saneamento básico extensivo a $100 \%$ da população, legislação adequada e monitoramento constante, enfrentam surtos esporádicos provocados por microoganismos presentes na água de abastecimento (AMERICAN WATER WORKS ASSOCIATION 1999).

A impossibilidade de se eliminar o risco de contaminação de doenças veiculadas pela água, faz com que medidas de prevenção sejam adotadas para minimizá-lo, obrigando por lei que toda a água destinada ao consumo humano seja submetida à desinfecção.

As bactérias, vírus e protozoários são os principais grupos de microoganismos oriundos da Natureza ou da contaminação por dejetos animais e humanos (WHO 2004) e nem todos são patogênicos, mas podem alterar as características físicas e organolépticas da água, tornando-a fora dos padrões de potabilidade.

Os microoganismos patogênicos provenientes de material fecal de humanos e animais homeotérmicos que podem ser encontrados na água são o grande problema para a saúde pública. 
As doenças de transmissão hídrica são aquelas nas quais a água é o veículo do agente infeccioso. Gastroenterites podem ser causadas por diferentes espécies de microoganismos. Enfermidades como faringoconjuntivite, foliculite, otite e pneumonia são transmitidas por microoganismos encontrados em águas recreacionais. Em situações onde há tratamento de água, as principais causas das epidemias são a falha no tratamento ou nos sistemas de distribuição.

As espécies de bactérias patogênicas que mais comumente causam doenças de transmissão hídrica são a Salmonella, Shigella, Campylobacter, O157:H7 (enteropatogênica), Vibrio cholerae, Leptospira spp., Legionella, Yersinia enterocolitica, Aeromonas spp.e Mycobacterium.

Os vírus excretados junto com as fezes de humanos infectados também têm importância na contaminação da água de abastecimento. Os vírus mais conhecidos são poliovírus, coxsakievírus, echovírus, adenovírus, reovírus, rotavírus, vírus causador da hepatite A e Norwalk. Com exceção do vírus da hepatite A, os demais consistem de muitos tipos sorológicos.

Algumas espécies de fungos e leveduras podem sobreviver aos sistemas de desinfecção de água. Os esporos de fungos podem sobreviver por longo tempo. A quantidade de cloro e o tempo de contato necessário para inativar os fungos é muito superior àquela requerida para a inativação da $E$. coli.

Os protozoários patogênicos constituem um grupo importante que podem causar problemas no suprimento de água de abastecimento. As espécies mais freqüentemente encontradas são a Giardia lamblia e o Cryptosporidium parvum. A água é contaminada através do depósito direto de fezes de animais silvestres, domésticos ou de humanos, ou através de descargas de esgoto em fontes utilizadas para abastecimento.

Algumas algas produzem toxinas, enquanto outras somente alteram as propriedades organolépticas da água. $\mathrm{O}$ curto ciclo de vida das microalgas faz com que a resposta a mudanças ambientais seja rápida e o desenvolvimento excessivo em certas condições requer intervenção rápida nos sistemas de tratamento da água.

A lei norte-americana de proteção da água de abastecimento, SDWA inclui um processo que deve ser acompanhado pela Agência de Proteção Ambiental (EPA) na identificação de novos contaminantes que deverão ser regulamentados no futuro. 
Periodicamente, a EPA anuncia uma lista de compostos candidatos a contaminantes, que podem ser químicos ou microbiológicos. Através da pesquisa e coleção de dados sobre esses candidatos é tomada a decisão na inclusão ou não dos mesmos no padrão oficial de potabilidade. Essa lista serve como modelo para leis brasileiras, como a Portaria 518/ 2004.

Atualmente, existem mais de 90 contaminantes regulamentados. Em fevereiro de 2005 , foi publicada a segunda lista com mais 51 candidatos. Os microorganismos incluídos nessa lista são: adenovirus, calicivirus, coxsackievirus, echovirus, Aeromonas hydrophila, cianobactérias, outras algas presentes em água doce e suas respectivas toxinas, Helicobacter pylori, Microsporidia (enterocytozoon e septata) e o Mycobacterium avium intracelulare.

Apesar do risco de contaminação da água sempre existir, a melhor maneira de se garantir sua qualidade consiste em preservar os mananciais sejam eles superficiais ou subterrâneos, protegendo-os da descarga de esgoto e dejetos, utilizar métodos de tratamento multi-barreiras, adequados e eficazes, realizar o controle de qualidade dos sistemas de distribuição desde a coleta até a distribuição e monitorar rotineiramente a qualidade da água.

Em procedimentos rotineiros, não se analisam os microoganismos patogênicos que poderiam estar presentes em situações de contaminação, mas sim os microoganismos indicadores de poluição fecal, aos quais os patogênicos podem estar associados.

Os microorganismos indicadores de contaminação fecal são selecionados de acordo com os seguintes critérios: estar presente em grandes quantidades em fezes de animais homeotérmicos incluindo os humanos, ser incapaz de multiplicar-se no ambiente aquático ou multiplicar-se menos do que as bactérias entéricas, apresentar persistência na água e resistência a desinfetantes semelhante aos microrganismos patogênicos de veiculação hídrica e ser mensurável por métodos laboratoriais rápidos e simples.

$\mathrm{O}$ objetivo do teste de coliformes totais realizado rotineiramente em suprimentos públicos de água, é de determinar a eficiência da operação da planta de tratamento, a integridade do sistema de distribuição e também é usado como varredura para a presença de contaminantes fecais. Uma alta proporção de ocorrência 
de coliformes em sistemas de distribuição pode ser atribuída não à falha do sistema de tratamento na planta ou no poço, mas no recrescimento nos canos principais. Pela dificuldade em se discernir o re-crescimento da nova contaminação, assume-se que todas as ocorrências de coliformes sejam novas, a não ser que o contrário seja demonstrado.

A Escherichia coli (E. coli), é a espécie mais utilizada como indicador por preencher o maior número de requisitos necessários. A $E$. coli é encontrada em esgoto, efluentes tratados, águas naturais e no solo. A presença específica da E.coli indica a contaminação fecal recente da água e consequientemente a possibilidade de coexistência de espécies patogênicas, não só de bactérias como vírus e protozoários. A detecção de $E$. coli requer imediata intervenção no sentido de se adotarem ações corretivas no tratamento da água.

Além dos testes tradicionais com a E.coli, coliformes termotolerantes e coliformes totais, os estreptocococos fecais, enterococos, Aeromonas, clostrídios sulfato-redutores e os bacterófagos foram propostos como indicadores para a avaliação da eficiência de tratamento da água (American Public Health Association, American Water Works Association e Water Environment Federation, 1998).

No Brasil, a portaria 518 de 2004 determina que na água para consumo humano em toda e qualquer situação, incluindo fontes individuais como poços, minas, e nascentes dentre outras, a Escherichia coli (preferencialmente) ou coliformes termotolerantes devem estar ausentes em volume de $100 \mathrm{~mL}$ de amostra. $\mathrm{Na}$ água na saída do tratamento, os coliformes totais devem estar ausentes em 100 $\mathrm{mL}$ e na água tratada no sistema de distribuição (reservatórios e rede), a Escherichia coli ou coliformes termotolerantes devem estar ausentes em $100 \mathrm{~mL}$.

Um único indicador nunca garante que a água esteja livre de patógenos. A escolha de se monitorar os indicadores pressupõe a compreensão dos parâmetros a serem medidos e a relação dos indicadores com os patógenos. Por outro lado, outros patógenos como Pseudomonas, Aeromonas, plesiomonas, Yersinia, Vibrio, Legionella e Mycobacterium nem sempre estão associados aos indicadores.

A verificação da presença de outros indicadores não biológicos também pode ser importante na coleta de informação sobre a contaminação patogênica da água. As características físico-químicas como turbidez, $\mathrm{pH}$, temperatura, carbono orgânico 
assimilável, oxigênio dissolvido, demanda bioquímica de oxigênio, concentração de amônia e a medida de cloro residual podem fornecer dados importantes sobre a contaminação da água.

\subsection{Procedimentos Utilizados na Avaliação da Qualidade Microbiológica da Água}

\subsubsection{Métodos Tradicionais}

Os métodos tradicionalmente utilizados na determinação da qualidade sanitária da água de abastecimento através de exames bacteriológicos são a técnica de tubos múltiplos e a técnica de membrana filtrante. Em ambos os casos, os testes verificam a presença de organismos indicadores, sendo o grupo dos coliformes fecais (ou termotolerantes) o principal indicador de contaminação fecal.

\subsubsection{Técnica de Tubos Múltiplos}

As bactérias do grupo coliforme são capazes de produzir gás como consequiência da fermentação da lactose, quando incubadas na temperatura de $35^{\circ} \mathrm{C}$ $\pm 0,5^{\circ} \mathrm{C}$. Algumas espécies desse grupo são capazes de realizar essa fermentação na temperatura de $44,5^{\circ} \mathrm{C}$ e são denominadas coliformes fecais ou termotolerantes. Tanto a técnica de tubos múltiplos quanto a membrana filtrante foram adaptadas para incorporar a incubação em temperaturas elevadas em testes confirmatórios para fornecer estimativas da densidade de coliformes fecais.

No teste de tubos múltiplos, os coliformes totais são examinados através de um procedimento que é dividido em três fases: presuntiva, confirmatória e completa. $\mathrm{Na}$ fase confirmatória, as amostras são inoculadas em concentrações decrescentes em séries de 5 tubos contendo caldo lauril triptose. Considera-se como resultado positivo a formação de gás e acidificação do meio, após incubação a $35 \pm{ }^{\circ} \mathrm{C}$ por 24 horas. Quando não ocorre formação de gás ou acidificação, estende-se a incubação por mais Os tubos com resultado positivo são então submetidas à segunda fase (inoculação em 
caldo verde brilhante e bile 2\%.) Observa-se a formação de gás após incubação a 35 $\pm 0,5^{\circ} \mathrm{C}$ pelo intervalo de $48 \pm 3$ horas.

Os resultados dessa técnica são apresentados em termos de NMP (número mais provável) dos organismos presentes. Esse número, baseado em cálculos estatísticos e apresentado em tabelas, é uma estimativa da densidade média dos coliformes na amostra. A densidade de coliformes, juntamente com outros dados obtidos por investigação sanitária e de engenharia, fornece a melhor avaliação da efetividade do tratamento de água e da qualidade da água.

A precisão do resultado de cada teste é diretamente proporcional ao número de tubos. A informação mais satisfatória é obtida quando os inoculados com as maiores concentrações de amostra apresentam formação de gás em todos ou quase todos os tubos e aqueles de menor concentração não apresentam gás em nenhum ou quase nenhum tubo (APHA, 1998). As tabelas de NMP são baseadas na distribuição de Poisson (dispersão aleatória). Porém, se as amostras não forem suficientemente homogeneizadas antes da remoção das porções ou se houver acúmulo de células, o valor do NMP poderá ser subestimado.

Quando uma amostra de água é analisada para se verificar se está dentro dos padrões estabelecidos pela legislação, usa-se a técnica de tubos múltiplos com 10 tubos com $10 \mathrm{~mL}$ cada, 5 réplicas com $20 \mathrm{~mL}$ cada, ou uma única amostra com 100 $\mathrm{mL}$.

A fase final é realizada com pelo menos $10 \%$ dos tubos positivos confirmados. São utilizados três meios de cultura a fim de diferenciar a presença de coliformes totais, fecais e E. coli. Para a detecção dos dois últimos, a incubação é realizada a $44 \pm 0,5^{\circ} \mathrm{C}$. Dentre estes tubos, aqueles que apresentarem formação de gás devem ser analisados por semeadura em dois diferentes meios de cultura sólidos, seguida de incubação a $35 \pm 0,5{ }^{\circ} \mathrm{C}$ por $24 \pm 2$ horas. Colônias isoladas são analisadas e aquelas que apresentarem aspecto típico são transferidas para tubos, contendo caldo lauril triptose. A incubação é realizada a $35 \pm 0,5{ }^{\circ} \mathrm{C}$ por $24 \pm 2$ horas. A formação de gás nesse meio, coloração de Gram negativa e teste negativo para oxidase constituem resultado positivo para a fase completa do teste, demonstrando a presença de um membro do grupo de coliformes. 
Uma das limitações dessa técnica consiste na falta de precisão, que pode ser compensada pela análise de um grande número de amostras. Assim, torna-se necessário grande cuidado na interpretação dos resultados obtidos do uso de poucos com cada diluição, principalmente quando o número de amostras de um determinado ponto de amostragem é limitado.

O resultado do cálculo da densidade bacteriana é dado em número mais provável (NMP). Existem tabelas apresentadas na (APHA, 1998) com os NMP para uma variedade de condições de ensaio.

Para a determinação de coliformes fecais, pode-se utilizar o procedimento em um único passo pode ser realizado utilizando-se um meio de cultura específico (caldo A-1). Os tubos são incubados inicialmente a $35 \pm 0,5^{\circ} \mathrm{C}$ durante 3 horas, e a seguir a $44,5 \pm 0,2^{\circ} \mathrm{C}$ durante 21 horas. A produção de gás com crescimento nesse meio de cultura no é interpretada como resultado positivo.

\subsubsection{Técnica de Membrana Filtrante}

Esta técnica é altamente reprodutível, pode ser utilizada para testar volumes relativamente grandes de amostra, usualmente gera resultados numéricos mais rapidamente do que o procedimento de fermentação em tubos múltiplos e é bastante útil no monitoramento de água de abastecimento. Por outro lado, a técnica apresenta também desvantagens quando a amostra apresenta alta turbidez ou um grande número de bactérias não coliformes. Em situações nas quais esta técnica nunca foi utilizada, recomenda-se que testes paralelos sejam conduzidos ara a verificação da aplicabilidade e comparabilidade.

Em relação a esta técnica, o grupo dos coliformes é definido como anaeróbio facultativo, gram-negativo, não formador de esporos, com forma de bastonete que desenvolve colônias vermelhas com um brilho dourado quando cultivado em meio tipo Endo contendo lactose, em um intervalo de 24 horas a $35^{\circ} \mathrm{C}$.

A turbidez causada pela presença de alga, partículas ou outros materiais podem não permitir a utilização desta técnica. Baixas estimativas de coliformes podem ser causadas pela presença de grande número de bactérias não-coliformes ou de substâncias tóxicas. 
A detecção de coliformes totais submetidos a condições adversas ao seu desenvolvimento, i.e. em águas de abastecimento, é realizada utilizando-se o método específico para organismos exauridos.

O volume-padrão a ser filtrado para águas de abastecimento é de $100 \mathrm{~mL}$, que pode ser dividido entre múltiplas membranas se necessário. Porém, em situações específicas como a resolução de um problema de água de abastecimento e identificação de coliformes no caso de vazamento em baixas concentrações de barreiras de tratamento, é preferível se testar amostras com volume de $1 \mathrm{~L}$.

Comparações estatísticas dos resultados obtidos pela técnica de tubos múltiplos e a técnica de membrana filtrante indicam que o segundo método é mais preciso. Dados de cada teste geram aproximadamente a mesma informação em termos de qualidade apesar dos resultados numéricos não serem idênticos.

Após a filtração, as membranas são transferidas para meio de cultura específico para coliformes. A incubação é realizada a $35 \pm 0,5^{\circ} \mathrm{C}$ durante 24 horas e as colônias com brilho verde-metálico são submetidas à fase confirmatória.

De acordo com a finalidade de uso da água e do tipo de amostra, a estringência do controle de qualidade pode ser aumentada através de testes de verificação. Os testes de verificação podem ser a fermentação da lactose, o teste de verificação rápida para citocromo oxidase $(\mathrm{CO})$ e $B$-galactosidase e o sistema multiteste comercialmente disponível.

A EPA determina que a água destinada ao suprimento público tenha apenas um registro de presença ou ausência de coliformes em amostras de $100 \mathrm{~mL}$ de volume, mas o Standard Methods for the Examination of Water and Wastewater (APHA, 1998) indica a determinação de densidades de coliformes em situações de amostragem repetida. Esse procedimento é particularmente importante na situação em que se suspeita da ocorrência da formação de biofilmes no sistema de distribuição de água para consumo humano. A magnitude da contaminação pode ser avaliada através da informação quantitativa de coliformes presentes.

Apesar da precisão desta técnica ser maior do que o método de fermentação em tubos múltiplos, a contagem de colônias na membrana pode subestimar o número de colônias viáveis. Utiliza-se uma tabela onde o número contado de colônias de bactérias coliformes é associado a limites superior e inferior de confidência de $95 \%$. 
Esses valores são obtidos com base na premissa de que as bactérias estão distribuídas aleatoriamente e seguem a distribuição de Poisson.

Uma das vantagens do uso desta técnica está na possibilidade de se adiar a realização do teste. Isto torna possível a coleta de material em local distante do laboratório, desde que a amostra seja filtrada imediatamente após a coleta e a membrana seja mantida em condições nas quais os organismos presentes na amostra continuem viáveis, mas que não cresçam durante o período de adiamento. A membrana filtrante deve ser mantida em meio de cultura contendo conservantes como o benzoato de sódio, e em casos onde há crescimento de fungos e leveduras, a cicloheximida. Alternativamente o meio M-ST (composto por fosfato; sulfanilamida; etanol e Tris) pode ser utilizado como meio de manutenção até que a membrana possa ser incubada no meio de cultura adequado, como no teste-padrão de membrana filtrante. Estudos prévios realizados com amostras de diferentes origens demonstraram que resultados análogos são obtidos entre o método de incubação adiada e a técnica-padrão, desde que os ensaios sejam efetuados no período de 72 horas desde a coleta.

A presença de bactérias pertencentes ao grupo dos coliformes fecais também pode ser determinada pela técnica de membrana filtrante. Como a especificidade do teste para coliformes fecais está diretamente relacionada à temperatura de incubação independendo da técnica adotada, utiliza-se a temperatura de $44 \pm 0,5^{\circ} \mathrm{C}$ por um período de 24 horas. As amostras de água são filtradas através da membrana filtrante. Esta é incubada no meio de cultura e na temperatura acima indicados. As colônias resultantes do crescimento de coliformes fecais apresentam coloração característica, distinta das colônias de não-fecais.

$\mathrm{O}$ procedimento de incubação adiada também pode ser utilizado para a verificação dos coliformes fecais de maneira análoga à contagem dos coliformes totais. Da mesma maneira como se procede com os coliformes totais, a amostra de água deve ser filtrada imediatamente após a coleta, a membrana filtrante mantida em meio conservante durante o período de adiamento e posteriormente transferida para o meio de cultura. As etapas que se seguem são as mesmas utilizadas para o procedimento de filtração de membrana para a verificação imediata de coliformes fecais. A aplicabilidade do teste deve ser confirmada para uma amostra de origem 
específica, comparando-se o resultado desta técnica com o obtido pelo método de tubos múltiplos.

A detecção de coliformes fecais a partir dos coliformes totais também pode ser realizada em águas de abastecimento dentro do prazo de 24 horas da coleta. A membrana filtrante apresentando resultado positivo para coliformes totais é transferida para um meio de cultura específico. A incubação é realizada à temperatura de $44,5 \pm 0,2^{\circ} \mathrm{C}$ por um período de $24 \pm 2$ horas. A produção de gás neste meio no período máximo de 24 horas é considerada como resposta positiva para coliformes fecais.

\subsubsection{Métodos Emergentes}

As duas referências que abordam de maneira abrangente as técnicas emergentes na detecção de coliformes na água para consumo humano, são a revisão de ROMPRÉ (2002) e as normas de qualidade de água publicada pela Organização Mundial da Saúde (ASHBOLT et al. 2004).

\subsubsection{Métodos Enzimáticos}

Apesar da técnica enzimática fazer parte das técnicas oficialmente reconhecidas pela American Public Health Association desde o ano de 1995, esta não é uma técnica clássica, de acordo com o Standard Methods for the Examination of Water and Wastewater (APHA 1998).

As duas únicas enzimas bacterianas reconhecidas em testes de detecção em água para consumo humano são a $\beta$-D-galactosidase para bactérias do grupo dos coliformes e a $\beta$-D-glucuronidase, específica da $E$. coli, anteriormente citadas. Dependendo da enzima escolhida, a especificidade pode variar de famílias até espécies de bactérias. As reações são rápidas e sensíveis. O potencial da técnica em detectar e enumerar as bactérias através de atividades enzimáticas específicas faz com que as técnicas enzimáticas também sejam inseridas no grupo das técnicas emergentes. 
Os métodos enzimáticos para a detecção de coliformes têm a vantagem sobre os métodos de tubos múltiplos e membrana filtrante por serem mais rápidos e mais sensíveis.

O teste de enzimático utiliza substratos hidrolizáveis para a detecção simultânea de enzimas produzidas por coliformes totais e pela E.coli. Em relação a este teste, o grupo dos coliformes totais é definido como todas as bactérias que expressam a enzima $B-D$-galactosidase, que cliva o substrato cromogênico e libera o cromógeno. A $\beta$-D-galactosidase catalisa a reação onde a lactose é quebrada em galactose e glicose. A espécie E.coli é definida como aquela que possui resposta positiva para os coliformes totais e sintetiza a enzima $\beta$-glucuronidase, a qual cliva o substrato fluorogênico, resultando na liberação do fluorógeno. Os testes podem ser realizados em tubos múltiplos, placas de microtitulação, membrana filtrante ou presença/ausência (presença ou ausência em uma única amostra de $100 \mathrm{~mL}$ ).

As espécies de bactérias que são classificadas sob o denominador comum de coliformes totais expressam a enzima B-D-galactosidase, cuja atividade é detectada através de substratos cromogênicos como o orto-nitrofenil-ß-D-galactopiranosídeo (ONPG) ou vermelho de clorofenol B-D-galactopiranosídeo (CPRG). A hidrólise do substrato produz uma mudança na coloração, que indica o resultado positivo para coliformes totais em um período que varia entre 24 horas (para a ONPG) e 28 horas (para CPRG), sem a necessidade de procedimentos adicionais. Alguns gêneros de bactérias não-coliformes tais como a Aeromonas e Pseudomonas expressam a enzima, mas não chegam a produzir resposta positiva dentro do período de incubação, a não ser que a concentração esteja acima de $10^{4} \mathrm{ufc} / \mathrm{mL}$.

A enzima $\beta$-glucuronidase catalisa a hidrólise de derivados $\beta$-Dglucopiranosidurônicos nos seus correspondetes aglicons e ácido D-glucurônico. Estudos realizados com a família Enterobacteriaceae (Kilian e Bulow, 1976) indicaram que a atividade desta enzima é encontrada somente na espécie E.coli. Diversos autores divergem quanto à presença desta enzima em isolados de E.coli. Kilian e Bulow,1976; Fent e Hartman, 1982; Edberg e Kontnick, 1986; Kaspar et al., 1987 testaram isolados de E. coli e verificaram reações positivas para a $\beta$-Dglucuronidase em 94-96\% das reações. Por outro lado, Chang et al (1989) não encontraram atividade desta enzima em $15 \%$ das amostras de E.coli isoladas de 
fezes humanas. Os gêneros Shigella, Salmonella, Yersinia e Flavobacteria apresentam pouca atividade desta enzima.

Experimentalmente, a atividade da enzima pode ser detectada pelo 4metilumberiferil-ß-D-glucuronideo (MUG), um substrato fluorogênico. Quando o substrato é clivado, o produto fluoresce sob a luz ultravioleta no comprimento de onde de $366 \mathrm{~nm}$. Algumas linhagens de Shiguella spp.também podem apresentar uma resposta positiva, mas cujo resultado não representa detrimento no teste da qualidade sanitária da água pois todas as espécies deste gênero são conhecidamente patogênicas.

Este teste é recomendado para análise da água de abastecimento, mas antes do estabelecimento deste procedimento, recomenda-se que seja realizado em paralelo com outros testes-padrão.

Os materiais utilizados em todos os métodos são comercialmente disponíveis e os métodos variam de acordo com o fabricante.

$\mathrm{Na}$ interpretação dos resultados, os tubos são examinados quanto à coloração. A hidrólise do ONPG resulta em solução de cor amarela e o CPRG em coloração vermelha. Para a E.coli, a análise deve ser efetuada sob luz ultra-violeta a $366 \mathrm{~nm}$. Os resultados são comparados com a referência comercialmente disponível. A presença de fluorescência é interpretada como resultado positivo para a E.coli.

Os resultados são elaborados em termos estatísticos utilizando-se o termo Número Mais Provável (NMP). O resultado do procedimento tudo-ou-nada, i.e., presença ou ausência, os resultados são relatados em termos de coliformes totais e presente ou ausente em volume de $100 \mathrm{~mL}$.

\subsubsection{Métodos Imunológicos}

O avanço da Imunologia nas últimas décadas permitiu que se desenvolvessem instrumentos imunológicos aplicáveis para funções diversas, incluindo a avaliação da qualidade microbiológica da água.

Da interação específica e de alta afinidade entre antígeno e anticorpo e do desenvolvimento de tecnologias que detectam quantidades pequenas dessa interação, resultaram métodos que puderam ser aplicados na avaliação da qualidade 
microbiológica da água de abastecimento. Uma das técnicas mais amplamente utilizadas é o imunoensaio enzimático denominado ELISA (enzyme-linked immunosorbent assay). Neste ensaio, dois anticorpos que reconhecem regiões distintas da proteína a ser detectada são utilizados. O primeiro anticorpo é ligado a um suporte polimérico e um segundo anticorpo é covalentemente ligado à fosfatase alcalina. Mediante a formação do complexo ternário (anticorpo-antígeno-anticorpo), a fosfatase alcalina converte um substrato incolor (ou não fluorescente) em produto colorido (ou fluorescente) que pode ser detectado por

Tanto ROMPRÈ (2002) quanto o guia da Organização Mundial da Saúde (OMS ou WHO), editado por FEWTRELL e BARTRAM (2004) citam OBST et al. (1989) por terem desenvolvido um método imunológico capaz de detectar bactérias pertencentes à família Enterobacteriaceae na água para consumo humano. A técnica de ELISA foi desenvolvida utilizando-se um anticorpo monoclonal contra o antígeno comum as enterobactérias (ACE), um lipopolissacarídeo ligado à membrana externa da bactéria. Porém, este ensaio não era suficientemente sensível e necessitava do précultivo da amostra em meio seletivo pelo período de 24 horas a fim de se atingir o limite de detecção de ELISA, que é de 100.000 células $/ \mathrm{mL}$. O método foi refinado por HÜBNER et al (1992) para a detecção rotineira e mostrou similaridade de $98 \%$ com o método-padrão de fermentação em tubos múltiplos. No mesmo trabalho, os autores observaram reação cruzada com linhagens de Pseudomonas, Aeromonas e Bacillus.

Apesar da alta sensibilidade do procedimento, as limitações estão associadas à falta de especificidade do anticorpo e à concentração tanto do anticorpo quanto do antígeno.

\subsubsection{Métodos baseados em ácidos nucléicos}

\subsection{PCR}

O PCR (polymerase chain reaction) ou a reação em cadeia da polimerase é uma técnica revolucionária por permitir que quantidades mínimas de DNA sejam amplificadas inúmeras vezes, através de ciclos de replicação (WHITE et al. 1989). 
As propriedades físico-químicas da molécula de DNA são utilizadas em muitos ciclos de desnaturação, hibridização com sequiências complementares e renaturação, com o auxílio de uma enzima termo-resistente, a Taq polimerase no processo de extensão da molécula de DNA.

Ao final de muitos ciclos previamente definidos, obtêm-se muitas cópias do DNA em questão. Esta técnica permite que seqüências específicas de DNA de coliformes ou de quaisquer outros organismos possam ser amplificadas a partir de concentrações muito baixas de DNA, sem que o laborioso e demorado passo do cultivo se faça necessário.

\subsection{Hibridização in situ}

Na técnica de hibridização in situ, sondas de oligonucleotídeos são utilizadas na detecção de seqüências complementares de ácidos nucleicos.

As sondas podem ser dirigidas tanto a moléculas de DNA quanto às de RNA. $\mathrm{O}$ uso de seqüências de RNA ribossômico (RNAr) $5 \mathrm{~S}, 16 \mathrm{~S}$ e $23 \mathrm{~S}$ no estudo das relações filogenéticas com base na divergência já está bem estabelecida (apud Amann et al., 1995). Assim, sequências conservadas dentro de diferentes níveis taxonômicos, podem ser detectadas. Sondas específicas para o RNAr (principalmente para as seqüências 16S e 23S) tornaram-se instrumentos-padrão para a identificação de organismos. Atualmente, são utilizados marcadores fluorescentes nas sondas. A técnica é denominada FISH (Fluorescent In Situ Hibridization).

A técnica apresenta vantagens sobre outras técnicas como a marcação radioativa, devido a maior sensibilidade, velocidade na visualização de células através de microscópios ou equipamentos citométricos, estabilidade dos produtos de hibridização, segurança, velocidade no tempo de detecção, possibilidade de uso de diversos marcadores (diferentes cores) e facilidade no uso.

Normalmente, as células hibridizadas são detectadas por microscópio de epifluorescência. Dependendo da concentração de células-alvo na amostra e para o aumento da resolução, a detecção pode ser realizada através do fluxo ou citometria de fase sólida. A citometria de fluxo permite a quantificação da intensidade de fluorescência para híbridos entre seqüência-alvo e sonda. 
Uma vez que o termo coliformes totais engloba diferentes gêneros, não é possível se desenvolver uma sonda a fim de se detectar especificamente o rRNA 16S deste grupo.Assim, as sondas se aplicam à família das Enterobacteriaceae e para a $E$. coli.

As limitações da técnica são observadas na detecção de bactérias que se encontram em situações de carência nutricional, como por exemplo, em água de abastecimento. Em condições inóspitas o metabolismo geral, e conseqüentemente a síntese protéica ficam restritos, refletindo no baixo conteúdo ribossômico. As poucas cópias de moléculas-alvo de $\mathrm{RNA}_{\mathrm{r}} 16 \mathrm{~S}$, resultam em um baixo sinal de fluorescência. O sinal fluorescente pode ser aumentado através de sistemas de amplificação de fluorescência como sondas múltiplas, propriedades interativas do complexo biotina-avidina e/ou peroxidase.

O uso de sondas de PNA (Peptide Nucleic Acid) pode ser uma alternativa na detecção de E. coli em água para consumo humano. O PNA é um ácido nucléico sintético no qual o açúcar (desoxirribose ou ribose) é substituído por um peptídeo. A vantagem no uso desta molécula está na maior resistência a ataques de nuclease, hibridização independente da força iônica e maior especificidade na ligação. Porém, antes que o PNA seja aceito como método sensível de enumeração de coliformes, a técnica deve ser sujeita à validação para que a sonda mais adequadas para as amostras analisadas possam ser escolhidas e para otimizar as condições de hibridização. A vialibilidade das células é a questão mais importante no uso desta técnica pra o monitoramento de contaminação da água de abastecimento. $\mathrm{O}$ conteúdo de rRNA das células bacterianas é diretamente relacionado à taxa de crescimento mas não reflete o estado fisiológico. Moléculas de rRNA de células submetidas ao calor, irradiação por UV ou até mesmo cloração, e portanto não cultiváveis, podem ser detectadas utilizando-se sondas de PNA. Torna-se necessária investigação mais aprofundada acerca do estado fisiológico das bactérias enumeras por FISH, com possibilidade de acoplamento da técnica de contagem de placas viáveis. 


\subsection{Biotecnologia e Avaliação da Qualidade da Água}

\subsubsection{Aspectos Gerais}

Os primeiros registros de fermentação da cerveja (que hoje sabemos ser realizada por microoganismos) vêm do Antigo Egito, o que não significa que aí esteja o início da Biotecnologia, pois para autores como Bud (1994), o trabalho de fermentação era realizado de maneira completamente diferente dos modernos tecnólogos. Portanto, com base no conceito em si, para este autor, a ênfase histórica deve ser centrada nos dois últimos séculos, quando as "ciências da vida" foram desvinculadas da Medicina, e tecnologias baseadas na Biologia começaram a surgir.

Para outros autores, os processos utilizados há milênios tais como a produção da cerveja, pão e queijo são considerados biotecnológicos, mas são denominados tradicionais por diferirem da "nova" biotecnologia (ou Biotecnologia Molecular) que surgiu a partir dos conhecimentos da Biologia Molecular. E foi justamente esta nova Biotecnologia que chamou a atenção de cientistas, economistas, jornalistas, governos e de toda a comunidade. Apesar da crescente importância que a Biotecnologia Molecular vêm apresentando nos últimos anos, vale frisar que ela representa apenas uma fração da biotecnologia tradicional. Com o uso de novas tecnologias, espera-se que nas próximas décadas a biotecnologia venha a ter um papel decisivo sobre a economia mundial.

O termo Biotecnologia foi utilizado pela primeira vez em 1917, por Karl Ereky, um engenheiro húngaro, para descrever um processo por ele desenvolvido na criação em larga-escala de porcos, onde se utilizaram raízes de beterraba como ração. Para Ereky, biotecnologia era "qualquer linha de trabalho onde os produtos eram obtidos com o auxílio de seres vivos" (MURPHY e PERRELLA,1993).

Por muitas décadas, o termo foi utilizado das mais diversas maneiras, e mesmo entre especialistas não havia consenso no significado da palavra Biotecnologia.

No início da década de 60, Carl G. Heden, associou o termo ao "estudo da produção industrial de bens e serviços por processos utilizando organismos, sistemas e processos biológicos". Desde então, entende-se Biotecnologia como uma área onde 
a microbiologia, bioquímica e a engenharia atuam conjuntamente. A Biotecnologia atual evoluiu a partir da zimotecnologia, a tecnologia das fermentações, que pode ser dividida em três grandes etapas:

1) processamento a montante: a matéria-prima é preparada para servir de fonte de alimento pra o microoganismo em questão;

2) fermentação e transformação: crescimento (fermentação) do microoganismo em um biorreator, com a consequente produção (biotransformação) do composto desejado. Por exemplo, uma proteína, um aminoácido ou um antibiótico.

3) processamento a jusante: o componente desejado é purificado da massa celular ou do meio de cultura.

A biotecnologia se dedica ao melhoramento da eficiência de cada uma dessas etapas, assim como dos microoganismos produtores de alimentos, suplementos alimentares, drogas, etc.

Nas décadas de 1960 e 1970, as áreas de bioinstrumentação para monitoramento e controle da fermentação evoluíram significativamente, levando á produção em larga-escala de diversos produtos.

A biotransformação é a fase mais difícil de ser otimizada. Uma vez que linhagens naturais geram produtos em quantidade abaixo do esperado, mutações eram induzidas quimicamente ou com o uso de radiação ultravioleta para criar mutantes que produzissem mais. Porém, estas estratégias apresentavam limitações biológicas, eram caras e demoradas. Além disso, o máximo que se poderia esperar tecnicamente seria o melhoramento de uma propriedade herdada por uma linhagem.

Com o desenvolvimento da tecnologia do DNA recombinante, a natureza da biotecnologia mudou radicalmente. Os problemas apresentados nos processos de biotransformação passaram a ser diretamente resolvidos. A engenharia genética possibilitou a criação de novas linhagens altamente produtivas.

Os próprios organismos, procariontes e eucariontes começaram a ser utilizados como fábricas biológicas na geração de um grande número de produtos. Novas drogas podem ser sintetizadas, terapias médicas inéditas e sistemas precisos de diagnósticos podem ser desenvolvidos, auxiliando na cura e prevenção de doenças genéticas e infecciosas. Na agricultura, plantas resistentes a insetos predadores, 
fungos e vírus podem ser criados. Na pecuária, animais podem ser desenvolvidos alterando-se certas características genéticas. Microorganismos podem produzir polímeros, aminoácidos, proteínas, enzimas e aditivos para indústria de alimentos. Substâncias encontradas na Natureza em quantidades mínimas podem ser produzidas em larga-escala, poluentes e dejetos podem ser removidos rapidamente do meio ambiente.

Assim, juntamente com as três disciplinas científicas anteriormente citadas (bioquímica, microbiologia e engenharia química) que deram início ao estudo da biotecnologia, hoje se incluem várias outras como Biologia Molecular, Genética, Biologia Celular, além da Economia, Filosofia e Ciências Sociais.

Neste trabalho será utilizada a definição de Biotecnologia determinada pela Organização para Cooperação e Desenvolvimento Econômicos (OECD, 2005): "Biotecnologia é a aplicação de princípios científicos e de engenharia no processamento de materiais por agentes biológicos a fim de prover bens e serviços".

\subsubsection{Biotecnologia e Água Destinada ao Consumo Humano}

A água tem sido tema de inúmeros encontros mundiais na área de Biotecnologia. O primeiro workshop, Biotecnologia para o uso e a conservação da água (México, 1996), demonstrou que a Biotecnologia poderia contribuir de maneira maciça para os vários problemas relativos água. $\mathrm{O}$ segundo, Tecnologias Moleculares para a água de abastecimento segura (Suíça ,1998), levantou a questão da necessidade de novas métodos para a medição e monitoramento de organismos patógenos. Neste encontro, os governos suíço e inglês fizeram três propostas relativas à água para consumo humano:

1) que se desenvolva um documento normatizando o teste microbiológico da água para consumo humano;

2) que haja uma coordenação internacional e promoção de métodos moleculares aplicados à área de água para consumo humano;

3) que se faça coordenação de esforços na área de vigilância e investigação de surtos decorrentes de contaminação da água de abastecimento. 
No encontro "Abordagens para estabelecer ligações entre a água para consumo humano e doenças infecciosas" (Inglaterra, 2000), chegou-se ao consenso sobre a importância da vigilância e do uso de novas tecnologias em epidemiologia molecular.

O G-77, a coalizão de países em desenvolvimento que compreende atualmente 134 países, realizou em Dubai no ano de 2002, a Conferência de alto nível em Ciência e Tecnologia. Desse encontro, resultou a Declaração de Dubai, na qual se estabelecem estratégias globais para o desenvolvimento baseado na Ciência.

Os três grandes temas abordados na declaração são: tecnologias da comunicação e da informação, Biotecnologia e acesso à água para consumo humano de boa qualidade.

Em relação aos dois últimos temas, a declaração proclama que os países participantes invistam na catalogação e desenvolvimento dos recursos genéticos. A atenção deve ser intensa quanto às preocupações políticas e éticas no uso de algumas técnicas oriundas da Biotecnologia.

Em termos de acesso à água de boa qualidade, a declaração invoca a necessidade de que o resultado das tecnologias desenvolvidas a partir da Ciência na produção de água para consumo humano de qualidade seja extensivo a todos os cidadãos.

Da reunião surgiu a proposta para criação de um fundo para a promoção do conhecimento e da tecnologia entre os países participantes e o estabelecimento de um consórcio da qual participariam representantes do governo, do setor privado e outras organizações relevantes.

Não há dúvida de que os produtos da Biotecnologia seriam de grande utilidade na questão da água de abastecimento, de maneira direta ou indireta. A maior questão consiste em assegurar que os benefícios dessa tecnologia serão estendidos para toda a Humanidade. 


\subsection{Fosfatase Alcalina}

As enzimas são os catalisadores biológicos, que aumentam a velocidade das reações bioquímicas em no mínimo, $10^{6}$ vezes. As características mais marcantes das enzimas são a força catalítica e a especificidade. Praticamente todas as enzimas são proteínas (STRYER, 1988).

As reações enzimáticas são controladas com alta precisão nos sistemas bioquímicos. $\mathrm{O}$ pH, ou seja, a concentração de íon hidrogênio é regulada através do tamponamento das reações.

Outros fatores que também influenciam a velocidade das reações enzimáticas são:a temperatura, a força iônica, o tipo de tampão e inibidores e ativadores. GLENN (1974) descreveu o aumento de atividade da fosfatase alcalina purificada de B.subtilis em presença de metais divalentes. A atividade máxima foi observada em $\mathrm{MgCl}_{2}$ ou $\mathrm{CaCl}_{2} 2,0 \mathrm{M}$. A exposição de E.coli a várias concentrações de íons $\mathrm{Zn}^{+2} \mathrm{e}$ $\mathrm{Cd}^{+2}$ resultaram em aumento da quantidade total de proteína e de proteínas que ligam íons metálicos. A atividade da fosfatase alcalina foi quatro vezes maior na presença desses íons. (COHEN et al., 1991).

Devido ao $\mathrm{pK}_{\mathrm{a}}$ alcalino da fosfatase alcalina, utilizam-se tampões cujo $\mathrm{pK}_{\mathrm{a}}$ é próximo ao da enzima. O tampão utilizado com maior freqüência em $\mathrm{pH}$ alcalino é o CAPS ácido (3-ciclohexilamino)1-propanesulfônico, cuja toxicidade é baixa. Os tampões também pode atuar como fosfoaceptores (STINSON 1991). Existem outros tampões que têm $\mathrm{pK}_{\mathrm{a}}$ elevado, mas não são recomendados por sua toxicidade. A metilamina $\left(\mathrm{pK}_{\mathrm{a}} 10,62\right)$ e a piperidina $\left(\mathrm{pK}_{\mathrm{a}} 11,12\right)$ são dois exemplos. Alguns tampões podem ser inertes, como o carbonato e a barbitona, outros inibitórios como a glicina e a propilamina e outros ainda ativadores como a dietanolamina.(TIEZ, 1986). Este tampão seria um candidato em ensaios futuros na determinação de uma condição experimental ideal para que concentrações baixas da enzima possam ser detectadas.

Apesar do termo fosfatase alcalina ser genérico, associado a fosfomonoesterases inespecíficas, com atividade ótima em $\mathrm{pH}$ alcalino e não necessariamente ligado à homologia na sequência de aminoácidos. 
TORRIANI (1960) descreveu as fosfatases ácida(pH ótimo 4-5) e básica (pH ótimo 8,5-9,5) encontradas em E.coli. A fosfatase alcalina só é detectada na ausência de Pi. Atualmente, sabe-se que a ausência de fosfato inogânico induz um complexo de genes e operons denominado regulon PHO (SPIRA, 1996). Um dos genes pertencentes ao regulon PHO é o gene phoA, que codifica a fosfatase alcalina. Esse estudo mostrou que a atividade enzimática em uma cultura pode ser regulada por uma ampla faixa através do controle da concentração de fosfato inorgânico no meio de cultura. O nível máximo de atividade é obtido com um meio na qual a concentração de fosfato é suficientemente baixa que se torna fator limitante de crescimento.

A fosfatase alcalina constitui $6 \%$ do total de massa de proteína celular (GAREN e LEVINTHAL, 1960). Os autores concluíram que o pH ótimo para o ensaio é 8 , em tampão Tris $1 \mathrm{M}$, em ensaios realizados com a enzima purificada.

SCHLESINGER e OLSEN (1970) desenvolveram um procedimento de purificação da enzima, na qual é obtido 1 grama de fosfatase alcalina pura a partir de $100 \mathrm{~L}$ de cultura.

A fosfatase alcalina de E.coli é uma metaloenzima homodimérica com 449 resíduos de aminoácidos por monômero, de massa molecular 94.000 (BRENNAN et al,1995), termoestável, localizada no espaço periplasmático da célula bacteriana (SCHLESINGER e OLSEN, 1970) e classificada como fosfomonoesterase não específica. A enzima é um protótipo de todas as fosfatases alcalinas, especialmente as de mamíferos. Apesar da baixa homologia (25-30\%) com as enzimas de levedura e mamíferos, os sítios ativos são altamente conservados (HOLTZ 1999).

Em $\mathrm{pH} 2,0$, as subunidades se dissociam, e as cadeias polipeptídicas renaturam completamente readquirindo a atividade enzimática.

A bactéria E.coli produz muitas formas da fosfatase alcalina eletroforeticamente separáveis (WANNER, 1996), que resultam da remoção parcial de um único resíduo Arg do $\mathrm{N}$-terminal da enzima madura. Uma vez que a enzima é um dímero, esta modificação parcial resulta em três diferentes formas da enzima: homodímero não modificado, heterodímero e homodímero modificado (NAKATA et al. 1987). 
No ensaio de atividade da fosfatase alcalina, o aumento na absorção a 410 $\mathrm{nm}$, resultante da desfosforilação do NPP gerando o nitrofenol, é acompanhado espectrofotometricamente com uma célula de caminho $1 \mathrm{~cm}$. Sob estas condições a atividade enzimática é linearmente dependente da concentração da enzima variando de 0,001 a 1,0 unidades de O.D./ min a $25^{\circ} \mathrm{C}$, e esse intervalo independe da concentração do substrato, quando este está em excesso de $0,1 \mathrm{mg} / \mathrm{mL}$. Neste caso, a atividade não é afetada pela adição de $0,01 \mathrm{M}$ de $\mathrm{Mg}^{+2}$ ao meio. Porém, se a concentração do tampão Tris é diminuída para $0,01 \mathrm{M}$, a atividade enzimática total só é atingida na presença de $\mathrm{Mg}^{+2}$.

Os primeiros ensaios realizados com a fosfatase alcalina foram descritos por Lowry,no final da década de 1950, quando ainda não tantos tampões sintéticos como atualmente. $\mathrm{O}$ autor utilizou-se do mesmo substrato, ou seja, do $p$-nitrofenil fosfato e o tampão utilizado foi o (LOWRY, 1957) 2-amino-2-metil-1-propanol na concentração 1M. O tampão foi utilizado em alta concentração para impedir mudança de $\mathrm{pH}$ por dissolução de $\mathrm{CO}_{2}$ atmosférico. A atividade enzimática neste tampão é aproximadamente o dobro daquela encontrada em tampão 0,1 M glicina.

Todas as isozimas da fosfatase alcalina são inibidas pelo fosfato, borato, oxalato e por íons cianeto, o que justifica a baixa atividade obtida nos ensaios realizados com tampão borato.

As características bioquímicas da fosfatase alcalina de bactéria permitiram que a enzima fosse intensamente estudada. BRENNAN et al (1995) desenvolveram um sistema de sensor molecular baseado na fosfatase alcalina engenheirada. Uma seqüência peptídica foi introduzida na superfície da enzima, criando assim um sítio de ligação para anticorpo. A atividade enzimática da enzima aumenta ou diminui com a ligação do anticorpo. 


\section{JUSTIFICATIVA}

As águas destinadas ao consumo humano são sistemas oligotróficos nos quais os microorganismos que possam estar aí presentes encontram-se em situações ambientais inóspitas. Conseqüentemente, a detecção dos mesmos torna-se difícil. A necessidade do desenvolvimento de métodos que permitam a detecção de microoganismos de maneira rápida, sensível e específica é urgente.

Diversas técnicas vêm sendo desenvolvidas com o objetivo de se avaliar a qualidade microbiológica da água.

No Brasil, o resultado de muitos anos de pesquisa na área biotecnológica, culminando nos vários projetos genoma, técnicas de química fina, nanotecnologias e desenvolvimento de biossensores, indica que o momento histórico é adequado para que a área de estudos ambientais também se utilize desses conhecimentos e os aplique inclusive na avaliação da qualidade da água de abastecimento.

Este trabalho é uma proposta inicial para se testar uma condição experimental específica, que é a medida da atividade da fosfatase alcalina em tampão CAPS $1 \mathrm{M}$ a $\mathrm{pH}$ 11. A simplicidade e a rapidez dos ensaios foram os motivos principais na escolha do tema, cujo desdobramento poderia servir como modelo no desenvolvimento de testes rotineiros de avaliação microbiológica da água.

Pela importância técnica do preparo de tampões considerando-se a temperatura e a força iônica, alguns ensaios adicionais com correção de temperatura e força iônica foram realizados. A literatura referente às características bioquímicas da fosfatase alcalina não esclarece a questão técnica do preparo do tampão, mas esta é uma variável de extrema importância. Muitos dos ensaios são realizados sem que esses efeitos sejam considerados e resultam em falhas quando não são feitas as compensações apropriadas (BEYNON e EASTERBY,1996). 


\section{3) OBJETIVOS}

\section{1) Objetivo Geral}

Testar a reprodutibilidade do resultado obtido em ensaio de atividade da fosfatase alcalina de E.coli, em tampão CAPS 1M pH 11.

\section{2) Objetivos Específicos}

Verificar a atividade da fosfatase alcalina de E.coli através de ensaios realizados em diferentes valores de $\mathrm{pH}$ com diferentes tipos de tampão, variando as linhagens, meios de cultura, concentração de fosfato inorgânico e ajuste de força iônica.

Fazer uma revisão bibliográfica acerca dos parâmetros de potabilidade, dos procedimentos tradicionais e emergentes utilizados na avaliação microbiológica da água. 


\section{MATERIAIS E MÉTODOS}

O propósito final dos ensaios era verificar a reprodutibilidade de um resultado anteriormente obtido, no qual havia sido observado que a atividade da fosfatase alcalina de E.coli era mais intensa em pH 11 do que em $\mathrm{pH} 8$ e 9. Para alcançar o objetivo, foram realizados vinte e um ensaios.

Algumas variáveis que influenciam a atividade enzimática foram testadas. Dentre elas estão: a quantidade de enzima expressa dependendo da linhagem e dos meios de cultura (com diferentes concentrações de íon fosfato), o tipo, a concentração e a força iônica do tampão.

Foram utilizadas as linhagens BS 7 e rpo $\mathrm{S}$ que expressam a enzima constitutivamente, assim como a linhagem do tipo selvagem, que expressa a fosfatase alcalina somente em condição de carência de fosfato inorgânico $\left(\mathrm{P}_{\mathrm{i}}\right)$. A linhagem BS 7 foi utilizada em vinte ensaios (todos, exceto ensaio15), a tipo selvagem em dez ensaios e a rpoS, em apenas um. A linhagem BS 7 foi escolhida pela expressão constitutiva da enzima. A rpo $\mathrm{S}$, menos disponível no laboratório, foi utilizada apenas. Esta linhagem expressa maior quantidade de enzima do que a BS 7. A bactéria do tipo selvagem foi incluída para comparação dos resultados.

Os meios de cultura (LB, T-salts e meio A na ausência e na presença de duas concentrações de $\mathrm{P}_{\mathrm{i}}$ ), e tampões em diferentes valores de $\mathrm{pH}$ (Tris/CAPS e borato). Em cinco ensaios, realizou-se o ajuste de $\mathrm{pH}$ em função da diferença entre a temperatura de preparo e a de uso, sendo que em quatro deles a força iônica também foi variada.

Quatro ensaios $(8,9,11$ e 12) foram realizados com culturas de bactéria mantidas em período variando de 24 horas a 2 semanas em solução de SDS/clorofórmio. Esta solução é utilizada quando o ensaio não é realizado logo após o cultivo das bactérias, preservando a enzima ativa.

O meio de cultura A foi utilizado para cultivo da bactéria em 14 ensaios, o meio LB em dez e T-salts em cinco ensaios. Em 16 ensaios os tampões Tris $1 \mathrm{M} \mathrm{pH} 8$ e 9, CAPS $1 \mathrm{M}$ pH 10 e 11 (sem variar a força iônica) foram utilizados e o tampão borato em dois ensaios. 
Com o objetivo de verificar os efeitos da temperatura e da força iônica, que são os fatores que mais influenciam o $\mathrm{pK}_{\mathrm{a}}$, quatro ensaios foram realizados com diferentes forças iônicas e com correção entre a temperatura de preparo e de uso do tampão.

O conjunto de linhagens, os meios de cultura nos quais estas foram cultivadas, os tampões, os ajustes de força iônica e temperatura, a manutenção em solução de preservação (SDS/clorofórmio), utilizados ou não em cada ensaio foi denominado condição de ensaio. Nos dezessete ensaios realizados sem que as variáveis, força iônica e temperatura fossem consideradas, existem 40 condições de ensaio (indicadas subscritas em parênteses na Tabela 23 no capítulo Resultados)

As condições experimentais estão resumidas na Tabela 22, que se encontra no final deste capítulo.

\subsection{Materiais:}

Todos os reagentes utilizados têm grau analítico.

\subsubsection{Linhagens da bactéria E.coli}

Foram utilizadas as linhagens de bactéria $E$. coli K12 MG 1655:

wt :(XIAO et al, 1991)

BS7: K12 MG $1655 \Delta($ pst SCAB-phoU)560:: Km.

rpoS: RH90: MC4100 rpoS::Tn10 (LANGE e HENGGE-ARONIS, 1991), provenientes do Instituto Weizmann de Israel.

A linhagem do tipo selvagem, denominada wt (wild type) expressa a fosfatase alcalina em concentração de fosfato abaixo de $0,1 \mathrm{mM}$. Já as linhagens BS 7 e rpoS expressam a enzima constitutivamente.

\subsubsection{Meios de Cultura}

\subsubsection{Meios de cultura líquidos}

\subsection{LB (Luria-Bertani)}

Bacto-triptona: $10 \mathrm{~g}$

Extrato de levedura: $5 \mathrm{~g}$

$\mathrm{NaCl}: 10 \mathrm{~g}$ 
Água bidestilada foi acrescentada para a obtenção de volume final de $1 \mathrm{~L}$. $\mathrm{O}$ pH foi ajustado para 7,5 com $\mathrm{NaOH}$.

A esterilização foi efetuada por autoclavagem.

\subsection{Meio A}

Tris: $14,53 \mathrm{~g}$ $\mathrm{NaCl}: 4,67 \mathrm{~g}$

$\mathrm{KCl}: 1,49 \mathrm{~g}$

$\mathrm{NH}_{4} \mathrm{Cl}: 1,07 \mathrm{~g}$

$\mathrm{Na}_{2} \mathrm{SO}_{4}: 0,42 \mathrm{~g}$

$\mathrm{MgCl} 2: 0,2 \mathrm{~g}$

$\mathrm{CaCl}_{2}: 0,029 \mathrm{~g}$

$\mathrm{ZnCl}_{2}: 2,0 \times 10^{-4} \mathrm{~g}$

bacto-peptona: $0,05 \mathrm{~g}$

Os reagentes, exceto a glicose, foram dissolvidos em aproximadamente 850 $\mathrm{mL}$ de água bidestilada para $1 \mathrm{~L}$ final de meio.

$\mathrm{O} \mathrm{pH}$ foi ajustado para o valor de $7,5 \mathrm{com} \mathrm{HCl}$ concentrado. $\mathrm{O}$ volume final foi acertado para 1L, e o meio foi esterilizado pelo processo de autoclavagem.

Antes do uso, adicionou-se glicose estéril para 0,5\% (m/v) final.

\subsection{T-salts (10x)}

$\mathrm{NaCl}: 46,8 \mathrm{~g}$

$\mathrm{KCl}: 15 \mathrm{~g}$

$\mathrm{NH}_{4} \mathrm{Cl}: 10,8 \mathrm{~g}$

Tris: $145,2 \mathrm{~g}$

$\mathrm{MgCl}_{2} \cdot 6 \mathrm{H}_{2} \mathrm{O}: 2 \mathrm{~g}$

$\mathrm{Na}_{2} \mathrm{SO}_{4}: 3,5 \mathrm{~g}$

$\mathrm{CaCl}_{2}$ 1M: $2 \mathrm{~mL}$

$\mathrm{ZnCl}_{2}$ 0,01M: $2 \mathrm{~mL}$

A solução 10 vezes concentrada foi obtida dissolvendo-se as quantidades dos sais acima descritas, em $900 \mathrm{~mL}$ de água bidestilada. $\mathrm{O} \mathrm{pH}$ foi ajustado para o valor de 7,5 com $\mathrm{HCl} 10 \mathrm{M}$. O volume foi completado para 1L. Alíquotas foram divididas em garrafas de vidro com tampa e autoclavadas.

Antes do uso, acrescentou-se glicose estéril para 0,2\% final. Para situações com presença de $\mathrm{P}_{\mathrm{i}}$, além da glicose acrescentou-se $\mathrm{KH}_{2} \mathrm{PO}_{4}$ estéril, para $1 \mathrm{mM}$ final. 


\subsubsection{Meios de cultura sólidos.}

Aos meios de cultura líquidos utilizados, acrescentou-se agar para $1 \%$ final antes da esterilização por autoclavagem.

Volumes de aproximadamente $35 \mathrm{~mL}$ foram distribuídos por placa de Petri de $90 \times 15 \mathrm{~mm}$.

Quando foi necessário adicionar-se antibiótico, o meio foi resfriado para temperaturas abaixo de $55^{\circ} \mathrm{C}$, antes da adição do mesmo.

\subsubsection{Antibiótico Canamicina $(25 \mathrm{mg} / \mathrm{mL})$}

A solução-estoque do antibiótico canamicina $(\mathrm{Km})$ foi preparada dissolvendo-se $25 \mathrm{mg}$ do sal em $900 \mu \mathrm{L}$ de água bidestilada. Após completa dissolução, o volume final foi ajustado para $1 \mathrm{~mL}$.

A solução foi esterilizada por filtração utilizando-se filtros Millipore descartáveis com porosidade de $0,22 \mu \mathrm{m}$ e diâmetro de $50 \mathrm{~mm}$.

A concentração de uso foi de $50 \mu \mathrm{g} / \mathrm{mL}$.

\subsubsection{Tampões}

4.1.4.1 Borato ou ácido bórico. $\mathrm{H}_{3} \mathrm{BO}_{3}$ (ácido bórico) $\mathrm{MM}=61,8$

Solução-estoque: $1 \mathrm{M}$.

Valores de pH utilizados: 8 a 13.

A solução em concentração $1 \mathrm{M}$ foi obtida dissolvendo-se $6,18 \mathrm{~g}$ de ácido bórico em $90 \mathrm{~mL}$ de água bidestilada. $\mathrm{O} \mathrm{pH}$ foi ajustado para os valores de 8 a 13 com $\mathrm{NaOH}$, e o volume final de $100 \mathrm{~mL}$ foi obtido com a adição de água bidestilada.(Beynon e Easterby, 1996).

4.1.4.2 CAPS (ácido N-ciclohexil-3-aminopropanosulfônico) MM=221.32

Solução-estoque: 1M.

Valores de $\mathrm{pH}$ preparados: 10 e 11. 
A solução com concentração $1 \mathrm{M}$ foi obtida dissolvendo-se $22,13 \mathrm{~g}$ de CAPS em $90 \mathrm{~mL}$ de água bidestilada. $\mathrm{O}$ pH foi ajustado para os valores de 10 e $11 \mathrm{com}$ ácido clorídrico concentrado, e o volume final de $100 \mathrm{~mL}$ foi obtido com a adição de água bidestilada.

Concentrações de $0,5 \mathrm{M}$ e $0,1 \mathrm{M}$ em ambos os pHs foram obtidas por diluição em água bidestilada.

4.1.4.3 Tris (2-amino-2-hydroximetil-1,3-propanediol). $\quad M M=121.1$

Solução-estoque: 1M.

Valores de $\mathrm{pH}$ preparados: 8 e 9.

Para se obter a concentração $1 \mathrm{M}$, dissolveram-se 121.1g de Tris-base em 800 $\mathrm{mL}$ de água bidestilada. $\mathrm{O} \mathrm{pH}$ foi ajustado para os valores 8 e 9, adicionando-se $\mathrm{HCl}$ concentrado.

Soluções de 0,5 e 0,1 M foram obtidas a partir de diluições da soluçãoestoque de $1 \mathrm{M}$.

\subsubsection{Outras soluções}

4.1.5.1 HCI (ácido clorídrico) $\mathrm{MM}=36,45$

Solução comercialmente disponível na concentração de $12 \mathrm{M}$.

4.1.5.2 KCl (cloreto de potássio) $\mathrm{MM}=74,55$ Sal para ajuste de força iônica

Solução-estoque com concentração $1 \mathrm{M}$.

A solução de concentração $1 \mathrm{M}$ de cloreto de potássio foi obtida dissolvendose $7,45 \mathrm{~g}$ do sal em água, para volume final de solução de $100 \mathrm{~mL}$.

4.1.5.3 $\mathrm{CHCl}_{3}$ (clorofórmio) $\mathrm{MM}=119,40$

O reagente é comercialmente obtido na forma anidra. 
4.1.5.4 KH2PO4 (dihidrogenofosfato de potássio) $=\mathbf{P}_{\mathbf{i}} \quad M M=136,00$

Solução-estoque com concentração $1 \mathrm{M}$

A solução-estoque foi obtida dissolvendo-se $13,6 \mathrm{~g}$ do sal em água bidestilada para o volume final de $100 \mathrm{~mL}$ de solução.

4.1.5.5 SDS (dodecil sulfato de sódio) $\quad M M=288,38$

Solução-estoque a $10 \%(\mathrm{~m} / \mathrm{v})$

A solução foi obtida dissolvendo-se $10 \mathrm{~g}$ do detergente em $100 \mathrm{~mL}$ de água.

4.1.5.6 $\mathrm{C}_{6} \mathrm{H}_{12} \mathrm{O}_{6}$ (glicose) $\mathrm{MM}=180,00$

Solução-estoque a $20 \%(\mathrm{~m} / \mathrm{v})$.

A solução-estoque foi obtida dissolvendo-se $20 \mathrm{~g}$ do açúcar em água, para o volume final de $100 \mathrm{~mL}$ de solução. A solução foi esterilizada utilizando-se filtro Millipore de $50 \mathrm{~mm}$ de diâmetro e $0,22 \mu \mathrm{m}$ de porosidade.

4.1.5.7 Solução de interrupção da reação enzimática $\mathrm{Na}_{2} \mathrm{HPO}_{4}$ (hidrogenofosfato de sódio) $\mathrm{MM}=142,00$

A solução de hidrogenofosfato de sódio com concentração $1 \mathrm{M}$ foi obtida dissolvendo-se $14,2 \mathrm{~g}$ do sal em água, em volume final de $100 \mathrm{~mL}$.

4.1.5.8 $\mathrm{NaOH}$ (hidróxido de sódio) $\mathrm{MM}=40,00$

Solução-estoque com concentração $10 \mathrm{~N}$.

A solução-estoque $10 \mathrm{~N}$ foi obtida dissolvendo-se $40 \mathrm{~g}$ de hidróxido de sódio em $80 \mathrm{~mL}$ iniciais de água e ajustando-se o volume final para $100 \mathrm{~mL}$ após completa dissolução do sal. 


\subsubsection{Substratos para a reação enzimática}

4.1.6.1 $\alpha$-naftil fosfato (sal dissódico de alfa-naftil fosfato) $M M=268,12$

Concentração de $2 \mathrm{mg} / \mathrm{mL}$ em Tris $1 \mathrm{M}$ (pH=8) misturada na proporção de 1:1 (v/v) com o corante Fast Blue (4'-Amino-2',5'-dietoxibenzanilida, MM=300,36).

4.1.6.2. pNPP ( $\mathrm{p}$-nitrofenil fosfato dissódico hexahidratado) $\mathrm{MM}=371,10$

Concentração da solução-estoque: $20 \mathrm{mg} / \mathrm{mL}$.

Para a obtenção da solução-estoque, dissolveram-se $20 \mathrm{mg}$ do sal em $1 \mathrm{~mL}$ do tampão em concentração desejada. 


\subsection{MÉTODOS:}

\subsubsection{Cultivo e manutenção de culturas bacterianas}

As linhagens de bactéria utilizadas (item 4.1.1) foram mantidas congeladas (estocagem a longo-prazo), em meio sólido (estocagem a curto-prazo) e cultivadas em meio líquido.

\subsubsection{Estocagem de longo-prazo}

Um frasco contendo $5 \mathrm{~mL}$ de meio de cultura líquido, estéril foi inoculado com uma colônia isolada de bactéria. A cultura foi incubada por 12 horas, sob aeração, a $37^{\circ} \mathrm{C}$.

Um inóculo de $0,85 \mathrm{~mL}$ dessa cultura após crescimento, foi transferido para um frasco estéril contendo $0,15 \mathrm{~mL}$ de glicerol estéril. A mistura foi homogeneizada suavemente.

A cultura glicerinada foi rapidamente congelada em banho de etanol com gelo seco e estocada a $-80^{\circ} \mathrm{C}$.

\subsubsection{Estocagem de curto-prazo}

Bactérias viáveis foram recuperadas a partir de estoques mantidos a $-80{ }^{\circ} \mathrm{C}$, retirando-se pequenas alíquotas da cultura glicerinada congelada com palitos estéreis, inoculadas sobre meio de cultura contendo agar em placas de Petri e incubadas por um período de 12 horas em estufa a $37^{\circ} \mathrm{C}$.

Essas placas contendo colônias isoladas, foram mantidas a $4{ }^{\circ} \mathrm{C}$, vedadas com filme plástico e estocadas invertidas por um período de 3 semanas a 1 mês.

Colônias isoladas da bactéria K12 MG 1655 wt e BS7 foram obtidas através de cultivo em placas de Petri contendo meio de cultura LB/agar ou LB/Km/agar, respectivamente.

\subsubsection{Cultivo de bactérias em meio líquido}

Meios líquidos apropriados (meio $\mathrm{A}$ com ou sem $\mathrm{P}_{\mathrm{i}}$ ) foram inoculados com colônias isoladas. As incubações foram realizadas sob aeração, por 12 horas a $37^{\circ} \mathrm{C}$, em plataforma giratória para tubos movimentando-se a $250 \mathrm{rpm}$. 


\subsubsection{Verificação da concentração bacteriana}

A quantificação da população bacteriana foi realizada medindo-se a absorbância a $540 \mathrm{~nm}\left(\mathrm{~A}_{540}\right)$. Em culturas saturadas, i.e., aquelas nas quais a $\mathrm{A}_{540}$ é superior a 1,0, realizaram-se diluições na proporção de 1:10. Considera-se a absorbância de valor 1,0 correspondente à concentração de $10^{9}$ células $/ \mathrm{mL}$.

\subsubsection{Preservação de cultura de bactéria em solução SDS 0,1\%/clorofórmio $22 \%$}

Bactérias cultivadas em meio líquido (item 4.2.1.3) foram mantidas em solução SDS $0,1 \%$ /clorofórmio $22 \%$, na proporção de 2:1 (2 volumes de cultura:1 volume de SDS/clorofórmio), a $4{ }^{\circ} \mathrm{C}$, por período variando de 12 horas até 14 dias.

\subsubsection{Teste rápido de verificação de expressão da fosfatase alcalina}

Para a verificação da expressão da fosfatase alcalina, adiciou-se-se uma gota em placas de Petri com culturas de E.coli. Nos casos positivos, i.e., presença da enzima, as colônias apresentaram coloração preta imediatamente após a adição, e nos casos negativos, não houve coloração. A provável reação é de que o substrato $\alpha$ naftil fosfato seja quebrado em $\alpha$-naftil $+\mathrm{P}_{\mathrm{i}}$. A reação entre o $\alpha$-naftil e o Fast Blue resulta na coloração preta.

\subsubsection{Ajuste de força iônica e temperatura}

Os cálculos para ajuste de força iônica considerando-se a diferença entre as temperaturas de preparo e de uso dos tampões foram realizados pelo programa de computador (BEYNON e EASTERBY, 1996), disponível no sítio:

http://www.bi.umist.ac.uk/buffers.html

A força iônica desejada foi obtida através da adição de $\mathrm{KCl}$.

\subsubsection{Ensaio de medida de atividade enzimática da Fosfatase Alcalina}

As linhagens de bactérias foram cultivadas por 12 horas, em meio apropriado, na presença ou ausência de fosfato inorgânico $\left(\mathrm{P}_{\mathrm{i}}\right.$, ítem 4.1.5.4), como descrito nos itens 4.2.1.3 e 4.2.2. 
Alíquotas de 0,5 a $1,0 \mathrm{~mL}$ foram dividas em tubos de polipropileno de capacidade $1,5 \mathrm{~mL}$ e centrifugadas a $4.500 \mathrm{x}$ g por 10 minutos a $4^{\circ} \mathrm{C}$. Os precipitados foram ressuspendidos em $1 \mathrm{~mL}$ de tampão adequado à reação (Tris, CAPS ou $\mathrm{H}_{3} \mathrm{BO}_{3}$ ) na concentração $0,1 \mathrm{M}$. Repetiu-se a centrifugação nas mesmas condições e novamente o precipitado foi ressuspendido no volume de 0,5 a $1,0 \mathrm{~mL}$ de tampão com concentração $0,1 \mathrm{M}$.

A concentração da população bacteriana foi determinada através da leitura da densidade óptica da solução diluída, no comprimento de onda de $540 \mathrm{~nm}$, em espectrofotômetro.

Em volumes de $800 \mu \mathrm{L}(2,15 \mu$ moles $)$ ou de $950 \mu \mathrm{L}(2,55 \mu$ moles $)$ de solução contendo $1 \mathrm{mg} / \mathrm{mL}$ (ou 2,69 nM) de pNPP em 1M de tampão apropriado, acrescentaram-se volumes variando de $25 \mu \mathrm{L}$ a $50 \mu \mathrm{L}$ de bactérias ressuspendidas no mesmo tampão, mas na concentração de $0,1 \mathrm{M}$, totalizando o volume de $1 \mathrm{~mL}$, em intervalos constantes (20 segundos). Após homogeneização, a reação foi incubada em banho úmido, a $37^{\circ} \mathrm{C}$ por 6 minutos.

A reação foi interrompida adicionando-se $250 \mu \mathrm{L}$ de $\mathrm{Na}_{2} \mathrm{HPO}_{4} 1 \mathrm{M}$ à reação, seguida de homogeneização vigorosa.

A mistura foi transferida para tubos de centrífuga e centrifugada a $12.000 \mathrm{x} \mathrm{g}$ por 10 minutos a $25^{\circ} \mathrm{C}$.

O sobrenadante foi coletado e sua absorbância foi lida em espectrofotômetro ajustado para a leitura a $410 \mathrm{~nm}$.

A atividade de Fosfatase Alcalina foi calculada através da equação:

$$
\text { U.E. }=\frac{A_{410} \times \text { Fator de Diluição }}{\text { tempo de reação }(\min ) \times A_{540}} \text {, na qual: }
$$

U.E. = unidades arbitrárias de enzima. Refere-se à atividade da enzima.

$A_{410}=$ absorbância medida do sobrenadante da reação.

Fator de Diluição = volume de suspensão de células utilizado na reação

$(25$ a $50 \mu \mathrm{L}) /$ volume total $(1250 \mu \mathrm{L})$.

tempo de reação = tempo total de reação expresso em minutos.

$A_{540}=$ absorbância medida no espectrofotômetro, 
no comprimento de onda de $540 \mathrm{~nm}$.

A maneira usual de se expressar a atividade de uma enzima consiste em determinar a absorbância a $410 \mathrm{~nm}$ e utilizar o coeficiente de extinção molar de valor $1,78 \times 10^{4} \mathrm{M}^{-1} \mathrm{~cm}^{-1}$ (POT et al.1991) para calcular a concentração do íon pnitrofenolato produzido na reação.

A concentração do produto da reação enzimática (íon p-nitrofenolato) é relacionada à absorbância pela lei de Beer-Lambert através da equação:

$$
A_{410}=\varepsilon \times c \times 1 \text {, na qual }
$$

$\mathrm{A}_{410}=$ absorbância determinada experimentalmente,

$\xi=$ coeficiente de extinção molar do produto, no caso, $1,78 \times 10^{4} \mathrm{M}^{-1} \mathrm{~cm}^{-1}$

$\mathrm{c}=$ concentração molar, a ser calculada

$\mathrm{l}(\mathrm{um})=$ comprimento atravessado pela luz dentro da cubeta, expresso em $\mathrm{cm}$

Neste estudo, para acompanhar a literatura relativa ao estudo da fosfatase alcalina da bactéria E.coli, a atividade foi expressa de uma maneira indireta, na qual é utilizado o termo U.E. (unidade de enzima), obtido pela equação acima descrita.

Concentrações inferiores a $50 \mu \mathrm{M}$ de Pi foram consideradas condições de carência. 


\section{Ensaio 1:}

Condições de ensaio:

Linhagem: E. coli BS 7 .

Meio de cultura: LB.

Leitura diluída.1:10 em água bidestilada $\mathrm{A}_{540}=0,15$, ou seja, $1,5 \times 10^{9}$ células $/ \mathrm{mL}$. Tampões utilizados: Tris ( $\mathrm{pH}=8,0)$ 0,1 e 1,0 M; Tris $(\mathrm{pH}=9,0)$ 0,1 e 1,0 M; CAPS $(\mathrm{pH}=10,0) 0,1$ e 1,0 M e CAPS $(\mathrm{pH}=11,0)$ 0,1 e 1,0 M.

Tubos com $950 \mu \mathrm{L}$ de substrato pNPP na concentração de $1 \mathrm{mg} / \mathrm{mL}$ em tampão correspondente na concentração de $1 \mathrm{M}$.

$50 \mu \mathrm{L}$ de suspensão de células dissolvidas em tampão $0,1 \mathrm{M}$, foram adicionados ao substrato, em intervalos de 20 segundos (s).

Brancos: 0,1 M tampão correspondente a cada $\mathrm{pH}$.

Temperatura de reação: $37^{\circ} \mathrm{C}$.

Tempo de reação: 6 minutos (min).

Interrupção da reação: $250 \mu \mathrm{L} 1 \mathrm{M} \mathrm{Na}_{2} \mathrm{HPO}_{4}$.

Sobrenadante coletado após centrifugação e leitura realizada a A 410

Valores de $\mathrm{pH}$ confirmados ao término da reação. 


\section{Ensaio: 2:}

Condições de ensaio:

\section{Linhagem: E. coli BS 7}

Bactérias direto da placa, sem cultivo prévio, dissolvidas em $500 \mu \mathrm{L}$ de meio de cultura 1X T-salts.

Leitura diluída 1: 10 em água bidestilada $\mathrm{A}_{540}=0,37$, ou seja, $3,7 \times 10^{9}$ céls $/ \mathrm{mL}$.

Tampões utilizados: Tris 0,1 e 1,0 M (pH=8,0); Tris 0,1 e 1,0 M (pH=9,0); CAPS 0,1 E $1,0 \mathrm{M}(\mathrm{pH}=10,0)$ CAPS $0,1 \mathrm{E} 1,0 \mathrm{M}(\mathrm{pH}=11,0)$, condição de ensaio (2) e $\mathrm{H}_{3} \mathrm{BO}_{3}$ 0,1 e $1,0 \mathrm{M}(\mathrm{pH}=11,0)$, condição de ensaio (3).

Tubos com $950 \mu \mathrm{L}$ de substrato pNPP na concentração de $1 \mathrm{mg} / \mathrm{mL}$ tampão correspondente $1 \mathrm{M}$.

$50 \mu \mathrm{L}$ de suspensão de células em tampão $0,1 \mathrm{M}$ foram adicionados ao substrato, em intervalos de $20 \mathrm{~s}$, além dos brancos.

Brancos: tampão 0,1 M para cada $\mathrm{pH}$.

Sobrenadante coletado e leitura realizada a $410 \mathrm{~nm}$.

Temperatura de reação: $37^{\circ} \mathrm{C}$.

Tempo de reação: 6 min.

Interrupção da reação: $250 \mu \mathrm{L} 1 \mathrm{M} \mathrm{Na} \mathrm{HPO}_{4}$

Sobrenadante coletado após centrifugação e leitura realizada a $410 \mathrm{~nm}$.

Valores de pH confirmados no final da reação. 


\section{Ensaio 3:}

Condições de ensaio:

Linhagem: E.coli BS 7.

Meio de cultura: LB.

Leitura diluída 1:10. $\mathrm{A}_{540}=0,36$, ou seja, $3,6 \times 10^{9}$ céls $/ \mathrm{mL}$.

Tampões utilizados: CAPS 0,5M ( $\mathrm{pH}=9,72)$; CAPS 0,5M $(\mathrm{pH}=10,21)$; CAPS $0,5 \mathrm{M}$ ( $\mathrm{pH}=10,72)$; CAPS $0,5 \mathrm{M}(\mathrm{pH}=11,21) ;$ CAPS $0,5 \mathrm{M}(\mathrm{pH}=11,72) ; \mathrm{H}_{3} \mathrm{BO}_{3} 0,5 \mathrm{M}$ $(\mathrm{pH}=8,0$ a 13,0$)$.

Os valores de pH do tampão CAPS foram corrigidos em função diferença entre a temperatura de preparo $\left(25^{\circ} \mathrm{C}\right)$ da solução e da temperatura de reação do ensaio $\left(37^{\circ} \mathrm{C}\right)$.

Tubos com $950 \mu \mathrm{L}$ de substrato pNPP na concentração de $1 \mathrm{mg} / \mathrm{mL}$ em tampão correspondente em concentração igual à condição de ensaio.

$50 \mu \mathrm{L}$ de suspensão de células em tampão $0,5 \mathrm{M}$ foram adicionados ao substrato, em intervalos de 20s.

Brancos: 0,1 M tampão para cada $\mathrm{pH}$.

Temperatura de reação: $37^{\circ} \mathrm{C}$.

Tempo de reação: $6 \mathrm{~min}$.

Interrupção da reação: $250 \mu \mathrm{L} \mathrm{Na}_{2} \mathrm{HPO}_{4} 1 \mathrm{M}$.

Sobrenadante coletado e leitura realizada a $410 \mathrm{~nm}$.

Valores de $\mathrm{pH}$ confirmados ao término da reação. 


\section{Ensaio 4:}

Condições de ensaio:

Linhagem: E.coli BS 7.

Meio de cultura: LB.

Leitura diluída 1: 10 em água bidestilada $\mathrm{A}_{540}=0,33$, ou seja, $3,3 \times 10^{9}$ céls $/ \mathrm{mL}$.

Tampões utilizados: Tris 0,1 e 1,0 M (pH=8,33) FI=0,44M e FI=0,96M; Tris 0,1 e $1,0 \mathrm{M}(\mathrm{pH}=9,33) \mathrm{FI}=0,44 \mathrm{M}$ e FI= 0,96M; CAPS 0,1 E $1,0 \mathrm{M}(\mathrm{pH}=9,77) \mathrm{FI}=0,96 \mathrm{M}$; $(\mathrm{pH}=10,21) ;(\mathrm{pH}=10,72) ;(\mathrm{pH}=11,21)$ e $(\mathrm{pH}=11,72)$.

Tubos com $950 \mu \mathrm{L}$ de substrato pNPP na concentração de $1 \mathrm{mg} / \mathrm{mL}$ em tampão correspondente em concentração igual à condição de ensaio.

$50 \mu \mathrm{L}$ de suspensão de células em tampão $0,1 \mathrm{M}$ foram adicionados ao substrato, em intervalos de 20 s, além dos brancos.

Brancos: 0,1 M tampão nos diferentes pHs.

Temperatura de reação: $37^{\circ} \mathrm{C}$.

Tempo de reação: 5 min.

Interrupção da reação: $250 \mu \mathrm{L} \mathrm{Na}_{2} \mathrm{HPO}_{4} 1 \mathrm{M}$.

Sobrenadante coletado após centrifugação e leitura realizada a $410 \mathrm{~nm}$.

Valores de $\mathrm{pH}$ confirmados ao término da reação. 


\section{Ensaio 5:}

Condições de ensaio:

Linhagem: E. coli BS 7.

Meio de cultura: LB.

Leitura diluída 1: $10 \quad \mathrm{~A}_{540}=0,48$, ou seja, 4,8 X 109 céls $/ \mathrm{mL}$.

Tampões utilizados: Tris $1,0 \mathrm{M}(\mathrm{pH}=8,33) \mathrm{FI}=0,44 \mathrm{M}$ e $\mathrm{FI}=0,96 \mathrm{M}$; $(\mathrm{pH}=9,33) \mathrm{FI}=$ 0,44M e FI= 0,96M; CAPS 1,0 M (pH=9,77) FI=0,96M; $(\mathrm{pH}=10,21) ;(\mathrm{pH}=10,72)$ $(\mathrm{pH}=11,21)$ e $(\mathrm{pH}=11,72)$.

Tubos com $975 \mu \mathrm{L}$ de substrato pNPP na concentração de $1 \mathrm{mg} / \mathrm{mL}$ em tampão correspondente em concentração igual à condição de ensaio.

$25 \mu \mathrm{L}$ de suspensão de células em tampão $0,1 \mathrm{M}$ foram adicionados ao substrato, em intervalos de 20 s além dos brancos.

Brancos: 0,1 M tampão para cada pH.

Temperatura de reação: $37^{\circ} \mathrm{C}$.

Tempo de reação: 5 min.

Interrupção da reação: $250 \mu \mathrm{L} \mathrm{1M} \mathrm{Na} \mathrm{HPO}_{4}$.

** Não foi centrifugado após a reação.

Leitura realizada a $\mathrm{A}_{410}$.

Valores de $\mathrm{pH}$ confirmados ao término da reação. 


\section{Ensaio 6:}

Condições de ensaio:

\section{Linhagem: E.coli BS 7.}

Meio de cultura: LB.

Leitura diluída 1: $10 \mathrm{~A}_{540}=0,29$, ou seja, $2,9 \times 10^{9}$ céls $/ \mathrm{mL}$.

Tampões utilizados: Tris 0,1 e $1,0 \mathrm{M}(\mathrm{pH}=8,33) \quad \mathrm{FI}=0,44 \mathrm{M}$.

$$
\mathrm{FI}=0,96 \mathrm{M} \text {. }
$$

$$
(\mathrm{pH}=9,33) \mathrm{FI}=0,44 \mathrm{M} \text {. }
$$$$
\mathrm{FI}=0,96 \mathrm{M} \text {. }
$$

CAPS 0,1 E $1,0 \mathrm{M}(\mathrm{pH}=9,77) \mathrm{FI}=0,96 \mathrm{M}$.

$$
\begin{aligned}
& (\mathrm{pH}=10,21) \mathrm{FI}=0,96 \mathrm{M} . \\
& (\mathrm{pH}=10,72) \mathrm{FI}=0,96 \mathrm{M} . \\
& (\mathrm{pH}=11,21) \mathrm{FI}=0,96 \mathrm{M} . \\
& (\mathrm{pH}=11,72) \mathrm{FI}=0,96 \mathrm{M} .
\end{aligned}
$$

Tubos com $975 \mu \mathrm{L}$ de substrato pNPP na concentração de $1 \mathrm{mg} / \mathrm{mL}$ em tampão correspondente em concentração 1,0 M.

$25 \mu \mathrm{L}$ de suspensão de células em tampão $0,1 \mathrm{M}$ foram adicionados ao substrato, em intervalos de 20 s, além dos brancos.

Brancos: 0,1 M tampão para cada pH.

Temperatura de reação: $37^{\circ} \mathrm{C}$.

Tempo de reação: 5 min.

Interrupção da reação: $250 \mu \mathrm{L} \mathrm{1M} \mathrm{Na} 2 \mathrm{HPO}_{4}$.

Sobrenadante coletado após centrifugação e leitura realizada a A 410

Valores de $\mathrm{pH}$ confirmados ao término da reação. 


\section{Ensaio 7:}

Condições de ensaio:

Linhagem: E.coli BS 7

Meio de cultura: LB.

Leitura diluída 1: $10 \mathrm{~A}_{540}=0,29$, ou seja, $2,9 \times 10^{9}$ céls $/ \mathrm{mL}$.

Tampões utilizados: Tris $1,0 \mathrm{M}(\mathrm{pH}=8,33) \mathrm{FI}=0,44 \mathrm{M}$.

$$
\begin{aligned}
& \mathrm{FI}=0,96 \mathrm{M} . \\
&(\mathrm{pH}=9,33) \mathrm{FI}=0,44 \mathrm{M} . \\
& \mathrm{FI}=0,96 \mathrm{M} . \\
& \text { CAPS 1,0 M(pH=9,77) FI=0,96M. } \\
&(\mathrm{pH}=10,21) \mathrm{FI}=0,96 \mathrm{M} \\
&(\mathrm{pH}=10,72) \mathrm{FI}=0,96 \mathrm{M} \\
&(\mathrm{pH}=11,21) \mathrm{FI}=0,96 \mathrm{M} \\
&(\mathrm{pH}=11,72) \mathrm{FI}=0,96 \mathrm{M}
\end{aligned}
$$

Tubos com $975 \mu \mathrm{L}$ de substrato pNPP na concentração de $1 \mathrm{mg} / \mathrm{mL}$ em tampão correspondente em concentração igual à condição de ensaio.

$25 \mu \mathrm{L}$ de suspensão de células em tampão $0,1 \mathrm{M}$ foram adicionados ao substrato, em intervalos de $20 \mathrm{~s}$, além dos brancos.

Brancos: 0,1 M tampão para cada valor de pH acima indicado.

Temperatura de reação: $37^{\circ} \mathrm{C}$.

Tempo de reação: 5 min.

Interrupção da reação: $250 \mu \mathrm{L} 1 \mathrm{M} \mathrm{Na}_{2} \mathrm{HPO}_{4}$.

Sobrenadante coletado após centrifugação e leitura realizada a $410 \mathrm{~nm}$.

Valores de $\mathrm{pH}$ confirmados ao término da reação. 


\section{Ensaio 8:}

Condições de ensaio:

TESTE DE ATIVIDADE APÓS FICAR 2 SEMANAS NO CLOROFÓRMIO-SDS (0,1\% SDS/ $22 \%$ clorofórmio).

Linhagens: E.coli MG 1655 wt e BS 7.

Meios de cultura: meio $\mathrm{A}+$ glicose; com ou sem $\mathrm{P}_{\mathrm{i}}$

Leitura diluída 1: 10:

Leitura da $\mathrm{A}_{540}$ wt (meio $\left.\mathrm{A}+\mathrm{Gli}\right)=0,145$ $1,4 \times 10^{9}$ células $/ \mathrm{mL}$

$$
\left(\text { meio } \mathrm{A}+\mathrm{Gli}+\mathrm{P}_{\mathrm{i}}\right)=0,33 \quad 3,3 \times 10^{9} \text { células } / \mathrm{mL}
$$

BS $7($ meio A + Gli $)=0,13$ $1,3 \times 10^{9}$ células $/ \mathrm{mL}$ $\left(\right.$ meio $\left.\mathrm{A}+\mathrm{Gli}+\mathrm{P}_{\mathrm{i}}\right)=0,34$ $3,4 \times 10^{9}$ células $/ \mathrm{mL}$

Retiraram-se alíquotas de $50 \mu \mathrm{L}$ do estoque de bactérias em SDS-clorofórmio que foram adicionadas a tubos contendo $950 \mu \mathrm{L}$ do substrato pNPP $(1 \mathrm{mg} / \mathrm{mL})$ em Tris 1,0 M (pH=8,0), (pH=9,0) CAPS 1,0 M (pH=10,0) e(pH=11,0), em intervalos de 20s, além dos brancos.

Brancos: 0,1 M tampão para cada pH acima indicado.

Temperatura de reação: $37^{\circ} \mathrm{C}$.

Tempo de reação: 6 min.

Interrupção da reação: $250 \mu \mathrm{L} 1 \mathrm{M} \mathrm{Na}_{2} \mathrm{HPO}_{4}$.

Sobrenadante coletado após centrifugação e leitura realizada a $410 \mathrm{~nm}$.

Valores de $\mathrm{pH}$ confirmados ao término da reação. 


\section{Ensaio 9:}

Condições de ensaio:

TESTE CONFIRMATÓRIO PARA COMPARAR COM RESULTADOS DO ENSAIO 8.

Linhagens: E.coli MG 1655 wt e BS 7.

Meio de cultura: meio A + glicose; com e sem $\mathrm{P}_{\mathrm{i}}$.

Leitura da $\mathrm{A}_{540}$ diluída 1: 10 em água bidestilada:

$$
\begin{array}{cc}
\text { wt }(\text { meio } \mathrm{A}+\mathrm{Gli})=0,15 & 1,5 \times 10^{9} \text { células } / \mathrm{mL} \\
\left(\text { meio } \mathrm{A}+\mathrm{Gli}+\mathrm{P}_{\mathrm{i}}\right)=0,3 & 3,0 \times 10^{9} \text { células } / \mathrm{mL} \\
\text { BS } 7 \text { (meio A + Gli })=0,4 & 4,0 \times 10^{9} \text { células } / \mathrm{mL} \\
\left(\text { meio } \mathrm{A}+\mathrm{Gli}+\mathrm{P}_{\mathrm{i}}\right)=0,34 & 3,4 \times 10^{9} \text { células } / \mathrm{mL}
\end{array}
$$

Retiraram-se alíquotas de $50 \mu \mathrm{L}$ do estoque de bactérias em SDS-clorofórmio, que foram adicionadas a tubos contendo pNPP $1 \mathrm{mg} / \mathrm{mL}$ em Tris $1,0 \quad \mathrm{M}$ $(\mathrm{pH}=8,0),(\mathrm{pH}=9,0)$, CAPS $1,0 \mathrm{M}(\mathrm{pH}=10,0) \mathrm{e}(\mathrm{pH}=11,0)$.

Tubos com $950 \mu \mathrm{L}$ de substrato pNPP na concentração de $1 \mathrm{mg} / \mathrm{mL}$ em tampão correspondente em concentração igual à condição de ensaio.

Temperatura de reação: $37^{\circ} \mathrm{C}$.

Tempo de reação: $7 \mathrm{~min}$.

Interrupção da reação: $250 \mu \mathrm{L} 1 \mathrm{M} \mathrm{Na}_{2} \mathrm{HPO}_{4}$.

Sobrenadante coletado após centrifugação e leitura realizada a $410 \mathrm{~nm}$.

Valores de $\mathrm{pH}$ confirmados ao término da reação. 


\section{Ensaio 10:}

Condições de ensaio:

Linhagens: E.coli wt e BS 7.

Meios de cultura: meio A + glicose; com ou sem $\mathrm{P}_{\mathrm{i}}$.

$$
\text { T-salts. }
$$

Leitura diluída 1: 10 em água bidestilada

Leitura da $\mathrm{A}_{540}$ wt $($ meio $\mathrm{A}+\mathrm{Gli})=0,17$

$1,7 \times 10^{9}$ células $/ \mathrm{mL}$

$$
\begin{aligned}
& \left(\text { meio } \mathrm{A}+\mathrm{Gli}+\mathrm{P}_{\mathrm{i}}\right)=0,34 \\
& \left(\mathrm{~T} \text {-salts }-\mathrm{P}_{\mathrm{i}}\right) \\
& \left(\mathrm{T} \text {-salts }+\mathrm{P}_{\mathrm{i}}\right)=0,29
\end{aligned}
$$

$3,4 \times 10^{9}$ células/mL

Não houve crescimento

$2,9 \times 10^{9}$ células $/ \mathrm{mL}$.

$$
\text { BS } 7 \begin{aligned}
(\text { meio } A+G l i)=0,14 \\
\\
\left(\text { meio } A+G l i+P_{i}\right)=0,31 \\
(\text { T-salts }) \\
\left(\text { T-salts }+P_{i}\right)=0,023
\end{aligned}
$$

$1,4 \times 10^{9}$ células $/ \mathrm{mL}$

$3,1 \times 10^{9}$ células $/ \mathrm{mL}$

Não houve crescimento

Pouco crescimento

Em função do crescimento precário das culturas, os centrifugados foram ressuspensos em 500 e $1000 \mu \mathrm{L}$ das soluções-tampão.

Retiraram-se alíquotas de $50 \mu \mathrm{L}$ do estoque de bactérias em SDS-clorofórmio, e adicionaram-se a tubos contendo pNPP $1 \mathrm{mg} / \mathrm{mL}$ em Tris $1,0 \mathrm{M}(\mathrm{pH}=8,0),(\mathrm{pH}=9,0)$ CAPS $1,0 \mathrm{M}(\mathrm{pH}=10,0) \mathrm{e}(\mathrm{pH}=11,0)$

A tubos contendo $950 \mu \mathrm{L}$ de substrato pNPP na concentração $1 \mathrm{mg} / \mathrm{mL}$ em tampão correspondente em concentração igual à condição de ensaio, foram adicionados 50 $\mu \mathrm{L}$ de suspensão de células em tampão $0,1 \mathrm{M}$ em intervalos de $20 \mathrm{~s}$, além dos brancos.

Temperatura de reação: $37^{\circ} \mathrm{C}$.

Tempo de reação: 7 min. 
Interrupção da reação: $250 \mu \mathrm{L} 1 \mathrm{M} \mathrm{Na} 2 \mathrm{HPO}_{4}$.

Sobrenadante coletado após centrifugação e leitura realizada $410 \mathrm{~nm}$.

Valores de pH confirmados ao término da reação. 


\section{Ensaio 11:}

Condições de ensaio:

Linhagens: E.coli MG 1655 wt e BS 7.

Meio de cultura: meio A + glicose; com ou sem $\mathrm{P}_{\mathrm{i}}$

Leitura diluída 1: 10 em água bidestilada

Leitura de $\mathrm{A}_{540}$ feita tubo a tubo.

Retiraram-se alíquota de $50 \mu \mathrm{L}$ do estoque de bactérias em SDS-clorofórmio, e adicionaram-se a tubos contendo pNPP $1 \mathrm{mg} / \mathrm{mL}$ em:

Tampões utilizados: Tris $1,0 \mathrm{M} \quad(\mathrm{pH}=8,0)$

$$
(\mathrm{pH}=9,0)
$$

CAPS $1,0 \mathrm{M}(\mathrm{pH}=10,0)$

$$
(\mathrm{pH}=11,0)
$$

Tubos com $950 \mu \mathrm{L}$ de substrato pNPP na concentração de $1 \mathrm{mg} / \mathrm{mL}$ em tampão correspondente em concentração igual à condição de ensaio.

$50 \mu \mathrm{L}$ de suspensão de células em tampão $0,1 \mathrm{M}$ foram adicionados ao substrato, em intervalos de $20 \mathrm{~s}$, além dos brancos.

Temperatura de reação: $37^{\circ} \mathrm{C}$.

Tempo de reação: $5 \mathrm{~min}$.

Interrupção da reação: $250 \mu \mathrm{L} \mathrm{Na}_{2} \mathrm{HPO}_{4} 1 \mathrm{M}$.

Sobrenadante coletado após centrifugação e leitura realizada a $410 \mathrm{~nm}$.

Valores de pH confirmados ao término da reação. 


\section{Ensaio 12:}

Condições de ensaio:

ENSAIO EM PRESENÇA DE SDS/ CLOROFÓRMIO (12 horas/ $\left.4^{\circ} \mathrm{C}\right)$.

Linhagem: E.coli $\mathrm{MG} 1655$ BS 7

Meios de cultura: Meio A + glicose; com ou sem $\mathrm{P}_{\mathrm{i}}$

$$
\text { T-salts }+\mathrm{Pi}
$$

LB

Leitura diluída 1: 10 em água bidestilada

Leitura da $\mathrm{A}_{540}$ (meio $\mathrm{A}$ ) $=0,2$

$$
\begin{aligned}
& \left(\text { meio } A+P_{i}\right)=0,18 \\
& \left(T \text {-salts }+P_{i}\right)=0,14 \\
& (L B)=0,22
\end{aligned}
$$

$2,0 \times 10^{9}$

$1,8 \times 10^{9}$ células $/ \mathrm{mL}$

$1,4 \times 10^{9}$ células $/ \mathrm{mL}$

$2,2 \times 10^{9}$ células $/ \mathrm{mL}$

Retiraram-se alíquotas de $50 \mu \mathrm{L}$ do estoque de bactérias preservadas em SDSclorofórmio, e adicionaram-se a tubos contendo pNPP $1 \mathrm{mg} / \mathrm{mL}$.

Tampões utilizados: Tris $1,0 \mathrm{M} \quad(\mathrm{pH}=8,0)$

$$
(\mathrm{pH}=9,0)
$$

CAPS $1,0 \mathrm{M}(\mathrm{pH}=10,0)$

$(\mathrm{pH}=11,0)$

Temperatura de reação: $37^{\circ} \mathrm{C}$.

Tempo de reação: $5 \mathrm{~min}$.

Interrupção da reação: $250 \mu \mathrm{L} 1 \mathrm{M} \mathrm{Na}_{2} \mathrm{HPO}_{4}$.

Sobrenadante coletado após centrifugação e leitura realizada a $410 \mathrm{~nm}$.

$\mathrm{pH}$ verificado ao término da reação. 


\section{Ensaio 13:}

Condições de ensaio:

Linhagem: E.coli MG 1655 BS7.

Meios de cultura: Inóculo feito em meio $\mathrm{A}+$ glicose; com ou sem $\mathrm{P}_{\mathrm{i}}$. T-salts + Pi.

LB.

Leitura diluída 1: 10 em água bidestilada.

Leitura da $\mathrm{A}_{540}$ (meio $\left.\mathrm{A}\right)=0,15$

$$
\begin{aligned}
& \left(\text { meio } \mathrm{A}+\mathrm{P}_{\mathrm{i}}\right)=0,24 \\
& \left(\mathrm{~T} \text {-salts }+\mathrm{P}_{\mathrm{i}}\right)=0,14
\end{aligned}
$$

$1,5 \times 10^{9}$ células $/ \mathrm{mL}$ $2,4 \times 10^{9}$ células $/ \mathrm{mL}$. $1,4 \times 10^{9}$ células/mL.

Tampões utilizados: Tris $1,0 \mathrm{M} \quad(\mathrm{pH}=8,0)$

$$
(\mathrm{pH}=9,0)
$$

CAPS 1,0 M (pH=10,0)

$$
(\mathrm{pH}=11,0)
$$

Tubos com $950 \mu \mathrm{L}$ de substrato pNPP na concentração de $1 \mathrm{mg} / \mathrm{mL}$ em tampão correspondente em concentração igual à condição de ensaio.

$50 \mu \mathrm{L}$ de suspensão de células em tampão $0,1 \mathrm{M}$ foram adicionados ao substrato, em intervalos de $20 \mathrm{~s}$, além dos brancos.

Temperatura de reação: $37^{\circ} \mathrm{C}$.

Tempo de reação: 5 min.

Interrupção da reação: $250 \mu \mathrm{L} 1 \mathrm{M} \mathrm{Na}_{2} \mathrm{HPO}_{4}$

Sobrenadante coletado após centrifugação e leitura realizada a $410 \mathrm{~nm}$.

Valores de $\mathrm{pH}$ confirmados ao término da reação. 


\section{Ensaio 14:}

Condições de ensaio:

Linhagem: E.coli MG 1655 BS 7

Meio de cultura: meio A + glicose;

$$
\begin{aligned}
& \text { meio } \mathrm{A}+\text { glicose }+0,1 \mathrm{mM} \mathrm{P}_{\mathrm{i}} \\
& \text { meio } \mathrm{A}+\text { glicose }+1 \mathrm{mM} \mathrm{P_{i }}
\end{aligned}
$$

Leitura diluída 1: 10 em água bidestilada

Leitura da $\mathrm{A}_{540}$ de cada um dos tubos.

Tampões utilizados: Tris $1,0 \mathrm{M}(\mathrm{pH}=8,0)$

$$
\begin{array}{r}
(\mathrm{pH}=9,0) \\
\text { CAPS } 1,0 \mathrm{M}(\mathrm{pH}=10,0) \\
(\mathrm{pH}=11,0)
\end{array}
$$

Tubos com $950 \mu \mathrm{L}$ de substrato pNPP na concentração de $1 \mathrm{mg} / \mathrm{mL}$ em tampão correspondente em concentração igual à condição de ensaio.

$50 \mu \mathrm{L}$ de suspensão de células em tampão $0,1 \mathrm{M}$ foram adicionados ao substrato, em intervalos de $20 \mathrm{~s}$, além dos brancos.

Temperatura de reação: $37^{\circ} \mathrm{C}$.

Tempo de reação: 6'.

Interrupção da reação: $250 \mu \mathrm{L} 1 \mathrm{M} \mathrm{Na}_{2} \mathrm{HPO}_{4}$

Sobrenadante coletado após centrifugação e leitura realizada a $410 \mathrm{~nm}$.

pHs checados após a reação. 


\section{Ensaio 15:}

Condições de ensaio:

Linhagem: E.coli wt

Meio de cultura: Meio A + glicose

$$
\begin{aligned}
& \text { Meio A + glicose }+100 \mu \mathrm{M} \mathrm{P} \\
& \text { Meio A + glicose }+1 \mathrm{mM} \mathrm{P}_{\mathrm{i}}
\end{aligned}
$$

Leitura diluída 1: 10 em água bidestilada

Leitura da $\mathrm{A}_{540}$ de cada um dos tubos.

Tampões utilizados:

$$
\begin{array}{r}
\text { Tris } 1,0 \mathrm{M}(\mathrm{pH}=8,0) \\
(\mathrm{pH}=9,0) \\
\text { CAPS 1,0 } \mathrm{M}(\mathrm{pH}=10,0) \\
(\mathrm{pH}=11,0)
\end{array}
$$

Tubos com $950 \mu \mathrm{L}$ de substrato pNPP na concentração de $1 \mathrm{mg} / \mathrm{mL}$ em tampão correspondente em concentração igual à condição de ensaio.

$50 \mu \mathrm{L}$ de suspensão de células em tampão $0,1 \mathrm{M}$ foram adicionados ao substrato, em intervalos de $20 \mathrm{~s}$, além dos brancos.

Temperatura de reação: $37^{\circ} \mathrm{C}$.

Tempo de reação: 6'.

Interrupção da reação: $250 \mu \mathrm{L} 1 \mathrm{M} \mathrm{Na}_{2} \mathrm{HPO}_{4}$.

Sobrenadante coletado após centrifugação e leitura realizada a $410 \mathrm{~nm}$.

$\mathrm{pH}$ verificado ao término da reação. 


\section{Ensaio 16:}

Condições de ensaio:

Linhagens: E.coli wt e BS 7.

Meio de cultura: Meio A + glicose;

Leitura da $\mathrm{A}_{540}$ de cada um dos tubos.

Tampões utilizados: Tris $1,0 \mathrm{M}(\mathrm{pH}=8,0)$

$$
(\mathrm{pH}=9,0)
$$

CAPS $1,0 \mathrm{M}(\mathrm{pH}=10,0)$

$$
(\mathrm{pH}=11,0)
$$

Tubos com $950 \mu \mathrm{L}$ de substrato pNPP na concentração de $1 \mathrm{mg} / \mathrm{mL}$ em tampão correspondente em concentração igual à condição de ensaio.

$50 \mu \mathrm{L}$ de suspensão de células em tampão $0,1 \mathrm{M}$ foram adicionados ao substrato, em intervalos de $20 \mathrm{~s}$, além dos brancos.

Temperatura de reação: $37^{\circ} \mathrm{C}$.

Tempo de reação: 5 min.

Interrupção da reação: $250 \mu \mathrm{L} 1 \mathrm{M} \mathrm{Na} \mathrm{HPO}_{4}$

Sobrenadante coletado após centrifugação e leitura realizada a $410 \mathrm{~nm}$.

$\mathrm{pH}$ confirmado ao término da reação. 


\section{Ensaio 17:}

Condições de ensaio:

Linhagens: E.coli wt e BS 7.

Meio de cultura: Meio A + glicose; com e sem Pi

Leitura diluída 1: 10 em água bidestilada

Leitura da $\mathrm{A}_{540}$ de cada um dos tubos.

Tampões utilizados: Tris $1,0 \mathrm{M} \quad(\mathrm{pH}=8,0)$

$$
(\mathrm{pH}=9,0)
$$

CAPS $1,0 \mathrm{M}(\mathrm{pH}=10,0)$

$$
(\mathrm{pH}=11,0)
$$

Tubos com $950 \mu \mathrm{L}$ de substrato pNPP na concentração de $1 \mathrm{mg} / \mathrm{mL}$ em tampão correspondente em concentração igual à condição de ensaio.

$50 \mu \mathrm{L}$ de suspensão de células em tampão $0,1 \mathrm{M}$ foram adicionados ao substrato, em intervalos de $20 \mathrm{~s}$, além dos brancos.

Temperatura de reação: $37^{\circ} \mathrm{C}$.

Tempo de reação: 6'.

Interrupção da reação: $250 \mu \mathrm{L} 1 \mathrm{M} \mathrm{Na}_{2} \mathrm{HPO}_{4}$

Sobrenadante coletado após centrifugação e leitura realizada a $410 \mathrm{~nm}$.

$\mathrm{pH}$ verificado ao término da reação. 


\section{Ensaio 18:}

Condições de ensaio:

Linhagens: E.coli wt e BS 7.

Meios de cultura: Meio A + glicose; com e sem Pi

Leitura diluída 1: 10 em água bidestilada

Leitura da $\mathrm{A}_{540}$ de cada um dos tubos.

Tampões utilizados: Tris $1,0 \mathrm{M} \quad(\mathrm{pH}=8,0)$

$(\mathrm{pH}=9,0)$

CAPS $1,0 \mathrm{M}(\mathrm{pH}=10,0)$

$(\mathrm{pH}=11,0)$

Tubos com $950 \mu \mathrm{L}$ de substrato pNPP na concentração de $1 \mathrm{mg} / \mathrm{mL}$ em tampão correspondente em concentração igual à condição de ensaio.

$50 \mu \mathrm{L}$ de suspensão de células em tampão $0,1 \mathrm{M}$ foram adicionados ao substrato, em intervalos de $20 \mathrm{~s}$, além dos brancos.

Temperatura de reação: $37^{\circ} \mathrm{C}$.

Tempo de reação: 6'.

Interrupção da reação: $250 \mu \mathrm{L} 1 \mathrm{M} \mathrm{Na}_{2} \mathrm{HPO}_{4}$

Sobrenadante coletado após centrifugação e leitura realizada a $410 \mathrm{~nm}$.

$\mathrm{pH}$ verificado ao término da reação. 


\section{Ensaio 19:}

Condições de ensaio:

Linhagem: E.coli BS 7

Meios de cultura: Meio A + glicose; com e sem Pi

T-s com Pi

LB

Leitura diluída 1: 10 em água bidestilada

Leitura da $\mathrm{A}_{540}$ de cada um dos tubos.

Tampões utilizados:

$$
\begin{array}{r}
\text { Tris } 1,0 \mathrm{M}(\mathrm{pH}=8,0) \\
(\mathrm{pH}=9,0) \\
\text { CAPS } 1,0 \mathrm{M}(\mathrm{pH}=10,0) \\
(\mathrm{pH}=11,0)
\end{array}
$$

Tubos com $950 \mu \mathrm{L}$ de substrato pNPP na concentração de $1 \mathrm{mg} / \mathrm{mL}$ em tampão correspondente em concentração igual à condição de ensaio.

$50 \mu \mathrm{L}$ de suspensão de células em tampão $0,1 \mathrm{M}$ foram adicionados ao substrato, em intervalos de $20 \mathrm{~s}$, além dos brancos.

Temperatura de reação: $37^{\circ} \mathrm{C}$.

Tempo de reação: 6'.

Interrupção da reação: $250 \mu \mathrm{L} 1 \mathrm{M} \mathrm{Na}_{2} \mathrm{HPO}_{4}$

Sobrenadante coletado após centrifugação e leitura realizada a $410 \mathrm{~nm}$.

$\mathrm{pH}$ verificado ao término da reação. 


\section{Ensaio 20:}

Condições de ensaio:

Linhagens: E.coli wt e BS 7.

Meio de cultura: Meio A + glicose sem Pi

Leitura da $\mathrm{A}_{540}$ de cada um dos tubos.

Tampões utilizados: Tris 1,0 M $\quad(\mathrm{pH}=8,0)$

$$
\begin{aligned}
& (\mathrm{pH}=9,0) \\
\text { CAPS 1,0 M } & (\mathrm{pH}=10,0) \\
& (\mathrm{pH}=11,0)
\end{aligned}
$$

Tubos com $950 \mu \mathrm{L}$ de substrato pNPP na concentração de $1 \mathrm{mg} / \mathrm{mL}$ em tampão correspondente em concentração igual à condição de ensaio.

$50 \mu \mathrm{L}$ de suspensão de células em tampão $0,1 \mathrm{M}$ foram adicionados ao substrato, em intervalos de $20 \mathrm{~s}$, além dos brancos.

Temperatura de reação: $37^{\circ} \mathrm{C}$.

Tempo de reação: 6'.

Interrupção da reação: $250 \mu \mathrm{L} 1 \mathrm{M} \mathrm{Na} 2 \mathrm{HPO}_{4}$

Sobrenadante coletado após centrifugação e leitura realizada a $410 \mathrm{~nm}$.

$\mathrm{pH}$ verificado ao término da reação. 


\section{Ensaio 21:}

Condições de ensaio:

Linhagens: E.coli wt; BS 7 e rpoS.

Meio de cultura: Meio A + glicose sem Pi

Leitura diluída 1: 10 em água bidestilada

Leitura da $\mathrm{A}_{540}$ de cada um dos tubos.

Tampões utilizados: Tris $1,0 \mathrm{M}(\mathrm{pH}=8,0)$

$$
(\mathrm{pH}=9,0)
$$

CAPS $1,0 \mathrm{M}(\mathrm{pH}=10,0)$

$$
(\mathrm{pH}=11,0)
$$

Tubos com $950 \mu \mathrm{L}$ de substrato pNPP na concentração de $1 \mathrm{mg} / \mathrm{mL}$ em tampão correspondente em concentração igual à condição de ensaio.

$50 \mu \mathrm{L}$ de suspensão de células em tampão $0,1 \mathrm{M}$ foram adicionados ao substrato, em intervalos de $20 \mathrm{~s}$, além dos brancos.

Temperatura de reação: $37^{\circ} \mathrm{C}$.

Tempo de reação: 6 min.

Interrupção da reação: $250 \mu \mathrm{L} 1 \mathrm{M} \mathrm{Na}_{2} \mathrm{HPO}_{4}$.

Sobrenadante coletado após centrifugação e leitura realizada a $410 \mathrm{~nm}$.

Valores de pH confirmados ao término da reação. 
TABELA 1: RESUMO DAS CONDIÇÕES EXPERIMENTAIS DOS ENSAIOS DE FOSFATASE ALCALINA DE E.coli

\begin{tabular}{|c|c|c|c|c|c|c|c|c|c|c|}
\hline \multirow{2}{*}{$\begin{array}{c}\mathbf{N}^{\mathbf{0}} \\
\text { ENSAIO }\end{array}$} & \multicolumn{3}{|c|}{ LINHAGEM } & \multicolumn{3}{|c|}{$\begin{array}{c}\text { MEIOS } \\
\text { de CULTURA } \\
\end{array}$} & \multirow{2}{*}{$\begin{array}{c}\text { TAMPÕES } \\
\begin{array}{c}(\mathbf{A}),(\mathrm{B}) \text { ou } \\
(\mathbf{C})^{5^{5}}\end{array}\end{array}$} & \multirow[t]{2}{*}{$\begin{array}{l}\text { AJUSTE } \\
\text { TEMP. }\end{array}$} & \multirow[t]{2}{*}{$\mathrm{FI}^{* 1}$} & \multirow[t]{2}{*}{$\begin{array}{c}\text { SDS/ } *^{2} \\
\text { CLOROF. }\end{array}$} \\
\hline & wt & BS 7 & rpoS & LB & $\underset{*^{3}}{\mathbf{A}+/-P i}$ & $\underset{*^{4}}{\mathbf{T}-\mathbf{s}}$ & & & & \\
\hline 1 & & SIM & & SIM & & & A & & & \\
\hline 2 & & SIM & & & & SIM & $\begin{array}{c}\mathrm{A}+ \\
1,0 \mathrm{M} \mathrm{H}_{3} \mathrm{BO}_{3} \\
11\end{array}$ & & & \\
\hline 3 & & SIM & & SIM & & & B & SIM & & \\
\hline 4 & & SIM & & SIM & & & $\mathrm{C}$ & SIM & SIM & \\
\hline 5 & & SIM & & SIM & & & $\mathrm{C}$ & SIM & SIM & \\
\hline 6 & & SIM & & SIM & & & $\mathrm{C}$ & SIM & SIM & \\
\hline 7 & & SIM & & SIM & & & $\mathrm{C}$ & SIM & SIM & \\
\hline 8 & SIM & SIM & & & $\mathrm{SIM}+/-$ & & A & & & SIM \\
\hline 9 & SIM & SIM & & & $\mathrm{SIM}+/-$ & & $\mathrm{A}$ & & & SIM \\
\hline 10 & SIM & SIM & & & $\mathrm{SIM}+/-$ & SIM & A & & & \\
\hline 11 & SIM & SIM & & & $\mathrm{SIM}+/-$ & & A & & & SIM \\
\hline 12 & & SIM & & SIM & $\mathrm{SIM}+/-$ & SIM & A & & & SIM \\
\hline 13 & & SIM & & SIM & SIM+/- & SIM & A & & & \\
\hline 14 & & SIM & & & SIM+/- & & $\mathrm{A}$ & & & \\
\hline 15 & SIM & & & & SIM+l- & & A & & & \\
\hline 16 & SIM & SIM & & & SIM-Pi & & A & & & \\
\hline 17 & SIM & SIM & & & SIM+/- & & $\mathrm{A}$ & & & \\
\hline 18 & SIM & SIM & & & SIM+l- & & A & & & \\
\hline 19 & & SIM & & SIM & SIM+l- & SIM & A & & & \\
\hline 20 & SIM & SIM & & & SIM-P $P_{i}$ & & A & & & \\
\hline 21 & SIM & SIM & SIM & & SIM- $P_{i}$ & & A & & & \\
\hline
\end{tabular}

*'1 Ajuste de força iônica

*2 Manutenção da cultura em solução de preservação SDS/clorofórmio

${ }^{3}$ Cultivo em meio A somente na presença $(+)$ ou ausência $(-)$ de fosfato inorgânico $\left(\mathrm{P}_{\mathrm{i}}\right)$, ou em ambas as condições experimentais (+/-)

$*{ }^{4}$ Cultivo em meio de cultura T-salts

${ }^{* 5}$ Tampões de ensaio: (A) Tris $1 \mathrm{M} \mathrm{pH} 8$ e 9 ; CAPS $1 \mathrm{M} \mathrm{pH} 10$ e11;

(B) CAPS $0,5 \mathrm{M} \mathrm{pH} 9,72$ a 11,$72 ; \mathrm{H}_{3} \mathrm{BO}_{3} 0,5 \mathrm{M} \mathrm{pH} 8$ a 13

(C) Tris $1 \mathrm{M} \mathrm{pH} 8,33$ e 9,33; CAPS $1 \mathrm{M} \mathrm{pH} 9,77$ a 11,72 


\section{III.2) RESULTADOS}

\section{Ensaio 1:}

\section{Tabela 2:}

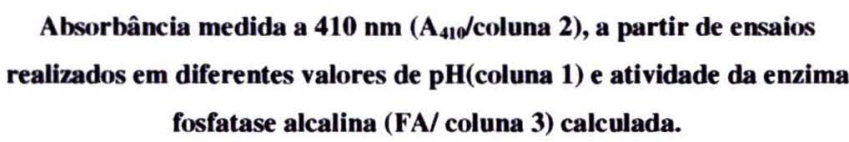

\begin{tabular}{|c|c|c|}
\hline $\mathrm{pH}$ & $\mathrm{A}_{410}$ & $\mathrm{FA}$ (U.E.) \\
\hline 8 & 0,51 & 1,43 \\
\hline 9 & 0,69 & 1,92 \\
\hline 10 & 0,30 & 0,83 \\
\hline 11 & 0,88 & 2,43 \\
\hline
\end{tabular}

\section{Figura 1:}

Ensaio 1: Absorbância a $410 \mathrm{~nm}$ e atividade da fosfatase alcalina em pH variando de 8 a 11

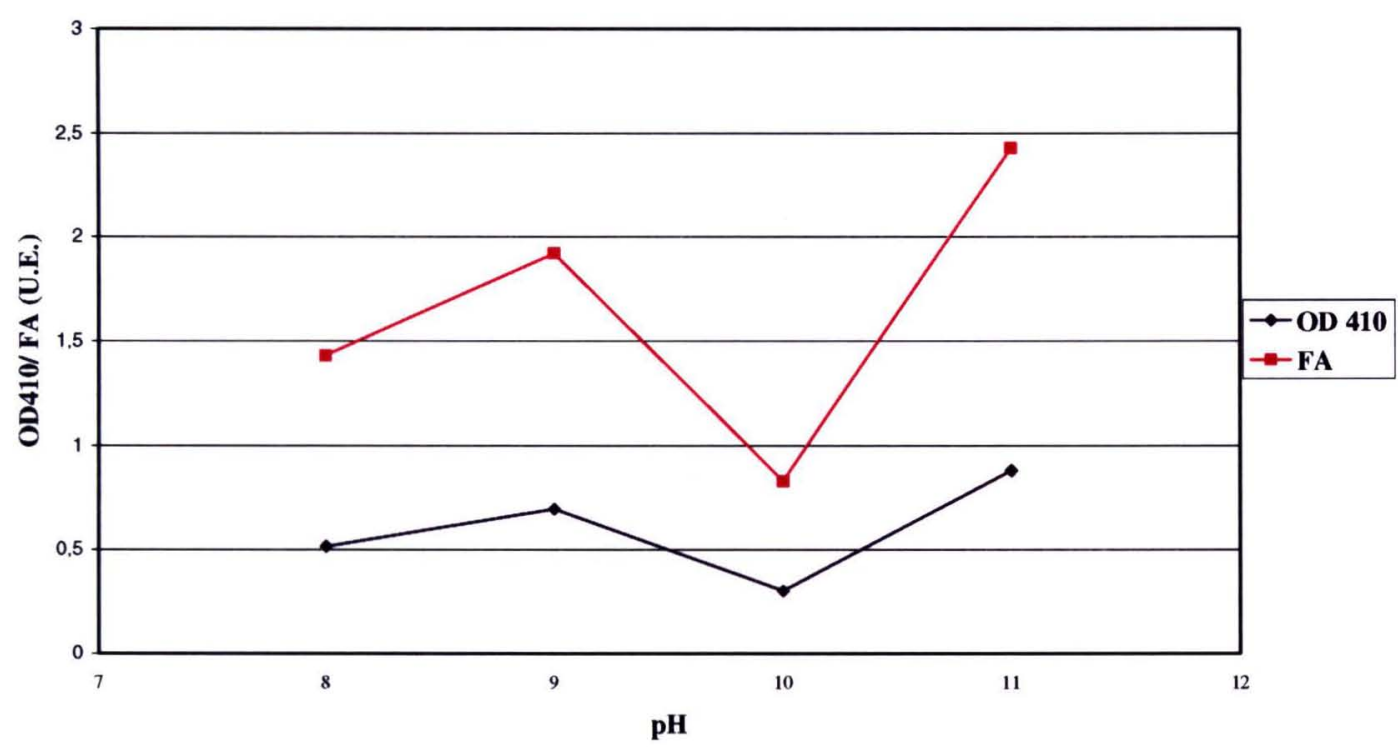

A atividade da enzima em tampão 1M CAPS em pH 11 é $70 \%$ maior do que aquela observada em tampão Tris $1 \mathrm{M}$ em pH 8 e $27 \%$ maior do que em $\mathrm{pH} 9$. A atividade é $193 \%$ (ou 2,93 vezes) menor em pH 10 do que em $\mathrm{pH} 11$. 


\section{Ensaio 2:}

\section{Tabela 3:}

Atividade da fosfatase alcalina (FA) calculada a partir de ensaios realizados em diferentes valores de $\mathrm{pH}$

\begin{tabular}{|c|c|}
\hline $\mathrm{pH}$ & $\mathrm{FA}$ (U.E.) \\
\hline 8 & 1,78 \\
\hline 9 & 1,64 \\
\hline 10 & 0,63 \\
\hline $11 \mathrm{CAPS}$ & 2,79 \\
\hline $11 \mathrm{H}_{3} \mathrm{BO}_{3}$ & 0,91 \\
\hline
\end{tabular}

Figura 2:

Ensaio 2: Atividade da fosfatase alcalina em $\mathrm{pH}$ variando de 8 a 11

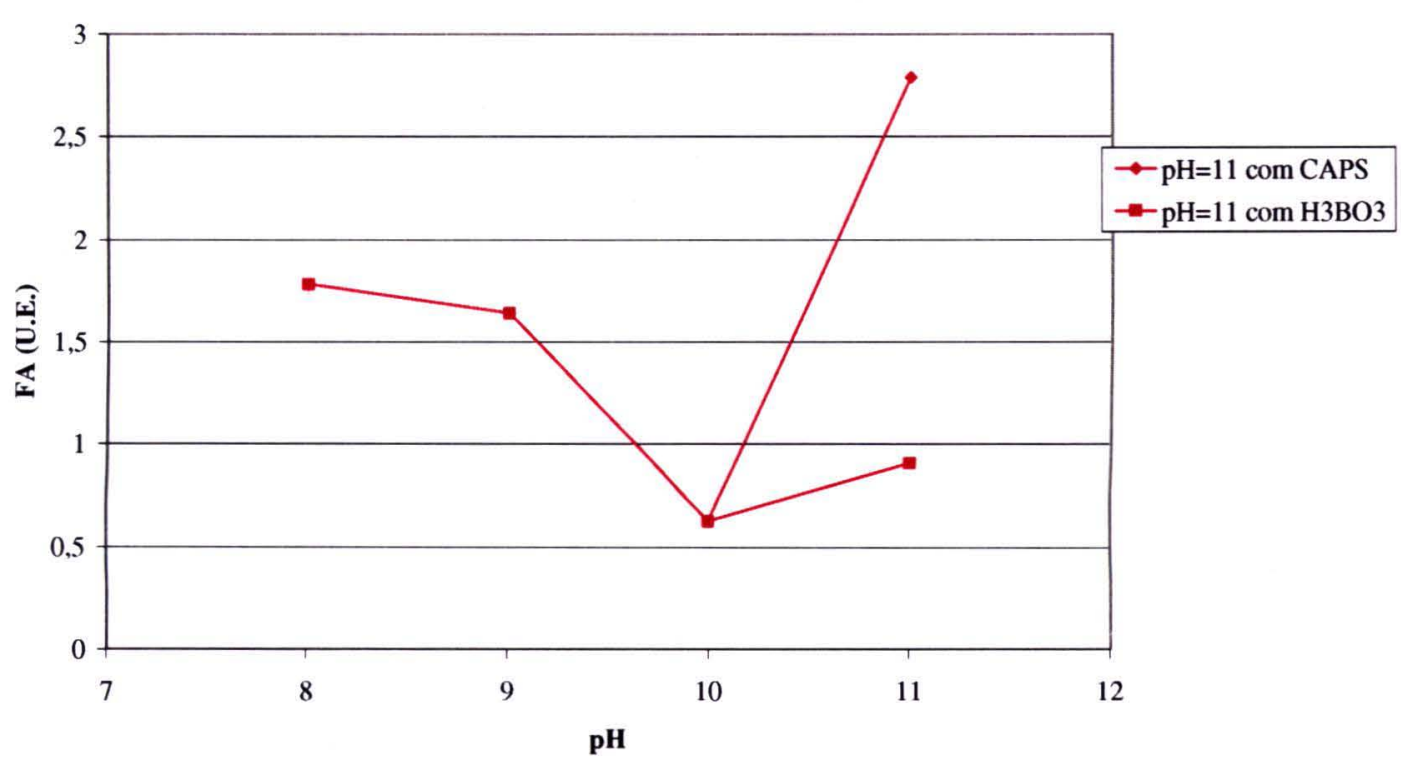

A atividade foi $57 \%$ maior em tampão CAPS $1 \mathrm{M}$ em $\mathrm{pH}=11$ do que em tampão Tris $1 \mathrm{M}$ em pH=8 e $70 \%$ maior do que em $\mathrm{pH}=9$.

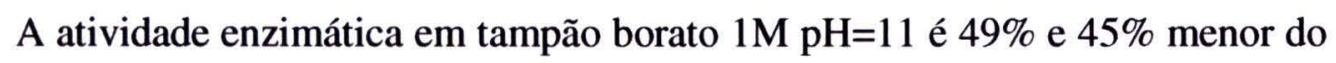
que em pH 8 e pH 9, respectivamente. 


\section{Ensaio 3:}

Tabela 4: Atividade de fosfatase alcalina(FA) calculada a partir de ensaios realizados em diferentes valores de $\mathrm{pH}$ nos tampões CAPS $0,5 \mathrm{M}$ (A) e $0,5 \mathrm{M} \mathrm{H}_{3} \mathrm{BO}_{3}(\mathrm{~B})$, nos quais a absorbância foi medida a $410 \mathrm{~nm}$.

\begin{tabular}{|c|c|c|c|c|c|}
\hline \multicolumn{3}{|c|}{ A) CAPS $0,5 \mathrm{M}$} & \multicolumn{3}{c|}{${\text { B) } \mathrm{H}_{3} \mathrm{BO}_{3} 0,5 \mathrm{M}}^{0,}$} \\
\hline $\mathrm{Ph}$ & $\mathrm{OD}_{410}$ & $\mathrm{FA}($ U.E. $)$ & $\mathrm{pH}$ & $\mathrm{OD}_{410}$ & FA(U.E.) \\
\hline 9,5 & 1,02 & 1,19 & 8 & 1,46 & 1,69 \\
\hline 10,0 & 1,33 & 1,54 & 9 & 1,76 & 2,04 \\
\hline 10,5 & 1,07 & 1,24 & 10 & 1,75 & 2,03 \\
\hline 11 & 0,91 & 1,06 & 11 & 0,99 & 1,15 \\
\hline 11,5 & 0,99 & 1,15 & 12 & 0,02 & 0,02 \\
\hline & & & 13 & 0,02 & 0,02 \\
\hline
\end{tabular}

\section{FIGURA 3:}

Ensaio 3: Atividade da fosfatase alcalina em função de pH

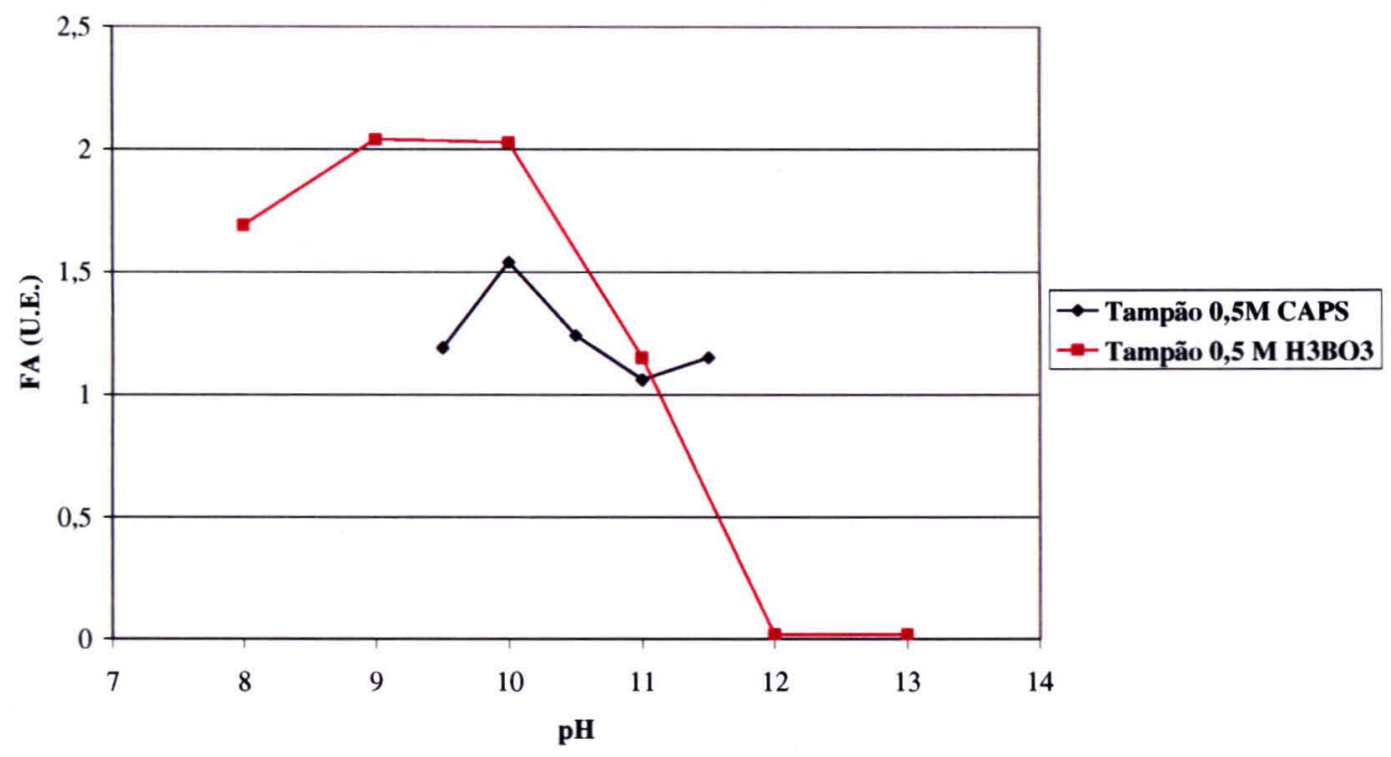

Em tampão CAPS $0,5 \mathrm{M}$ pH 11, a atividade foi $11 \%$ menor do que em CAPS $0,5 \mathrm{M} \mathrm{pH} 9,5,37 \%$ e $48 \%$ menor do que em borato $0,5 \mathrm{M} \mathrm{pH} 8$ e $\mathrm{pH} 9$, respectivamente. 
Em tampão borato $0,5 \mathrm{M} \mathrm{pH} 11$, a atividade foi $32 \%$ e $44 \%$ menor do que em pH 8 e 9 (no mesmo tampão), respectivamente. A atividade foi $3 \%$ menor do que em tampão CAPS 0,5M pH 9,5.

A atividade em pH 11 borato $0,5 \mathrm{M}$ foi $8 \%$ maior do que em tampão CAPS 0,5M, no mesmo $\mathrm{pH}$.

Não foi observada atividade enzimática não é observada em pH 12 e 13, em tampão borato.

Entre o pH 8 e 10,5 observa-se que a atividade da enzima é maior em tampão borato do que em tampão CAPS. Em pH 10, a atividade é $32 \%$ maior em tampão borato. 


\section{Ensaio 4:}

Tabela 5: Absorbância medida a $410 \mathrm{~nm}$ e atividade da Fosfatase Alcalina (FA) calculada a partir de ensaios realizados em diferentes valores de $\mathrm{pH}$ ajustados em função da temperatura de reação e da força iônica (FI)

\begin{tabular}{|c|c|c|c|}
\hline $\mathrm{pH}$ & FI & $\mathrm{A}_{410}$ & $\mathrm{FA}$ \\
\hline 8,33 & 0,44 & 0,47 & 7,1 \\
\hline 9,33 & 0,44 & 0,45 & 6,8 \\
\hline & & & \\
\hline 8,33 & 0,96 & 0,33 & 5,0 \\
\hline 9,33 & 0,96 & 0,54 & 8,0 \\
\hline 9,77 & 0,96 & 0,30 & 4,5 \\
\hline 10,3 & 0,96 & 0,35 & 5,2 \\
\hline 10,8 & 0,96 & 0,37 & 5,6 \\
\hline 11,4 & 0,96 & 0,29 & 4,3 \\
\hline 11,7 & 0,96 & 0,17 & 2,6 \\
\hline
\end{tabular}

Figura 4:

Ensaio 4: Atividade da fosfatase alcalina em diferentes valores de pH e forças iônicas

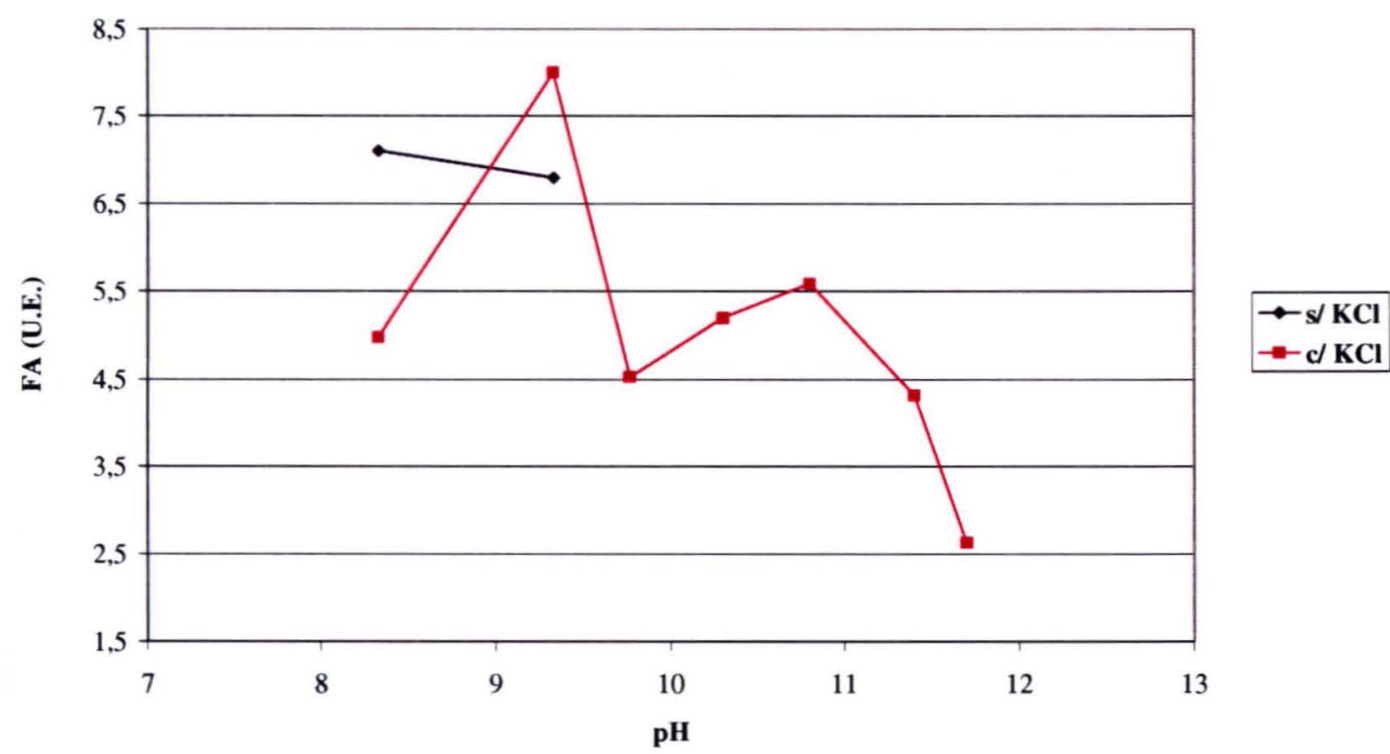

Observa-se que em $\mathrm{pH} 8,33$, a atividade da fosfatase alcalina obtida foi $43 \%$ maior em baixa força iônica (i.e. sem adição de $\mathrm{KCl}$ ) do que em força iônica de 0,96M. Em pH 9,33, o contrário foi observado. A atividade foi $15 \%$ menor em baixa força iônica. 
Em força iônica de 0,96 M, a atividade máxima é observada em $\mathrm{pH} 9,33$ tampão Tris 1M. Em pH 9,77, há uma diminuição de 1,77 vezes, ou seja, a atividade é $44 \%$ menor do que em $\mathrm{pH} 9,33$.

A atividade em pH 10,8 é $12 \%$ maior e $30 \%$ menor em relação ao $\mathrm{pH} 8,33$ e 9,33. Em pH 11,4, ela é $14 \%$ e $46 \%$ menor e em pH $11,7,48 \%$ e $67 \%$ menor, sempre em relação ao pH e 9,33, respectivamente. 


\section{Ensaio 5:}

Tabela 6: Densidade óptica medida a $410 \mathrm{~nm}$ e atividade da fosfatase alcalina (FA) calculada a partir de ensaios realizados em diferentes valores de pHs ajustados em função da temperatura de reação e da força iônica (FI).

\begin{tabular}{|c|c|c|c|}
\hline $\mathrm{pH}$ & $\mathrm{s} / \mathrm{KCl}$ & $\mathrm{A}_{410}$ & $\mathrm{FA}$ \\
\hline 8,33 & 0,44 & 0,86 & 12,81 \\
\hline 9,33 & 0,44 & 1,36 & 20,26 \\
\hline 9,70 & 0,18 & 0,32 & 4,77 \\
\hline 10,21 & 0,42 & 0,70 & 10,43 \\
\hline 10,71 & 0,71 & 1,25 & 18,62 \\
\hline 11,21 & 0,88 & 0,57 & 8,49 \\
\hline & $\mathrm{c} / \mathrm{KCl}$ & & \\
\hline 8,33 & 0,96 & 1,05 & 15,65 \\
\hline 9,33 & 0,96 & 1,69 & 25,18 \\
\hline 9,70 & 0,96 & 0,71 & 10,58 \\
\hline 10,21 & 0,96 & 1,20 & 17,88 \\
\hline 10,71 & 0,96 & 1,19 & 17,73 \\
\hline 11,21 & 0,96 & 0,86 & 12,81 \\
\hline 11,71 & 0,96 & 0,42 & 6,26 \\
\hline
\end{tabular}

\section{Figura 5:}

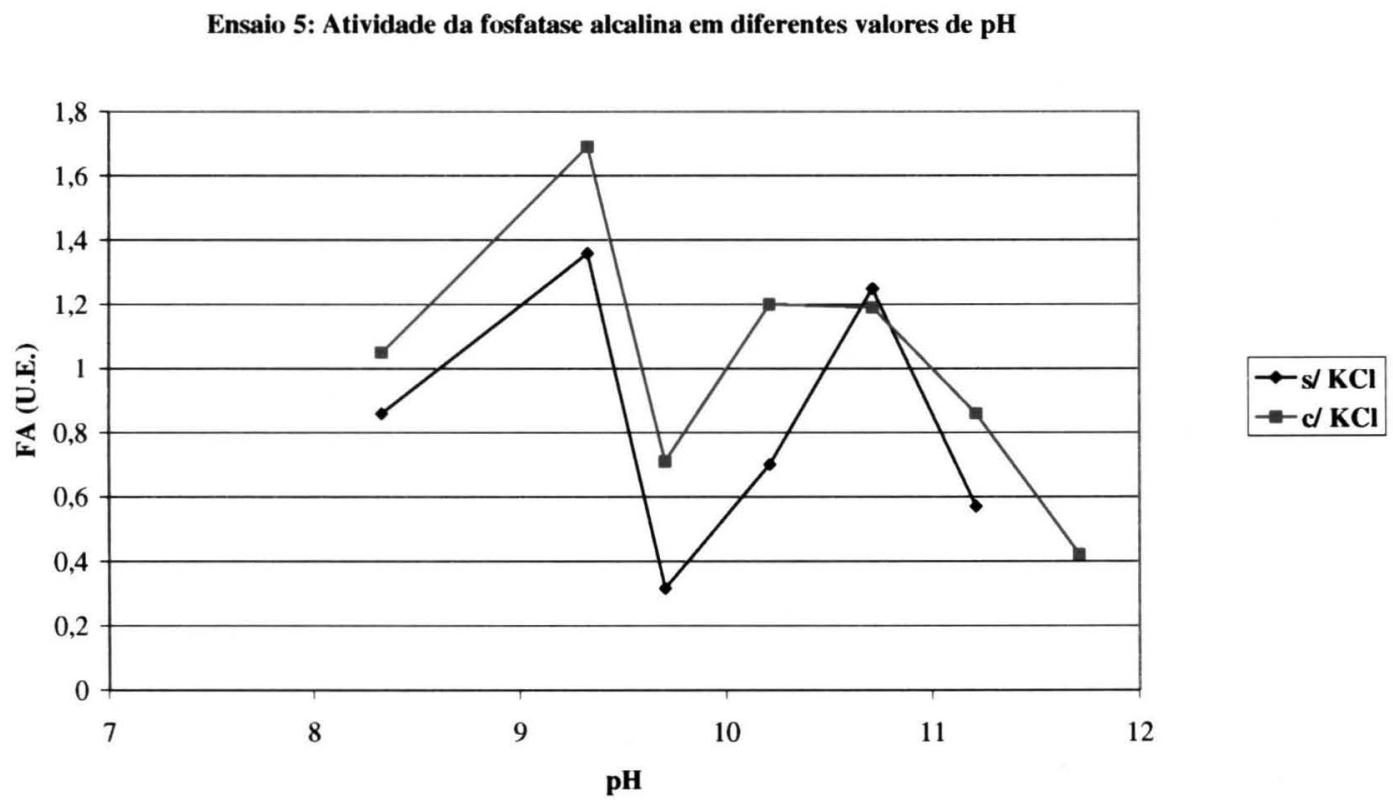

A atividade enzimática observada foi maior em $0,96 \mathrm{M} \mathrm{KCl}$.

Comparando-se os resultados obtidos entre o pH 11,21 com pH 8,33 e 9,33, sem adição de $\mathrm{KCl}$, observa-se que atividade é respectivamente, $34 \%$ e $58 \%$ menor 
em pH 11,21. Em força iônica de 0,96 M, observou-se diminuição na atividade enzimática em pH 11,21. Neste pH, a diferença de força iônica com e sem $\mathrm{KCl}$ é de apenas 0,08 M. Esta foi $18 \%$ e $49 \%$ (ou 1,22 e 1,96 vez) menor quando comparada à atividade em $\mathrm{pH} 8,33$ e 9,33, respectivamente.

A diferença aumenta para $60 \%$ e $75 \%$, quando os resultados são comparados com a atividade em $\mathrm{pH} 11,71$, ou seja, a atividade é 2,5 e 4 vezes menor em $\mathrm{pH}$ 11,71 do que em $\mathrm{pH} 8,33$ e 9,33 . 


\section{Ensaio 6:}

Tabela 7: Densidade óptica medida a $410 \mathrm{~nm}$ e atividade da Fosfatase Alcalina (FA) calculada a partir de ensaios realizados em diferentes pHs ajustados em função da temperatura de reação e da força iônica (FI).

\begin{tabular}{|c|c|c|c|c|}
\hline $\mathrm{pH}$ & $\begin{array}{c}+/- \\
\mathrm{KCl}\end{array}$ & $\mathrm{FI}$ & $\mathrm{A}_{410}$ & $\mathrm{FA}$ \\
\hline $8,33 \mathrm{~T}$ & $\mathrm{~s} / \mathrm{KCl}$ & 0,44 & 0,67 & 1,65 \\
& $\mathrm{c} /$ & 0,96 & 0,79 & 1,94 \\
\hline $9,33 \mathrm{~T}$ & $\mathrm{~s} / \mathrm{KCl}$ & 0,44 & 1,04 & 2,56 \\
& $\mathrm{c} /$ & 0,96 & 1,25 & 3,07 \\
\hline $9,71 \mathrm{C}$ & $\mathrm{s} / \mathrm{KCl}$ & 0,18 & 0,33 & 0,81 \\
& $\mathrm{c} /$ & 0,96 & 0,68 & 1,67 \\
\hline $10,21 \mathrm{C}$ & $\mathrm{s} / \mathrm{KCl}$ & 0,42 & 0,78 & 1,92 \\
& $\mathrm{c} /$ & 0,96 & 1,02 & 2,51 \\
\hline $10,71 \mathrm{C}$ & $\mathrm{s} / \mathrm{KCl}$ & 0,70 & 0,93 & 2,29 \\
& $\mathrm{c} /$ & 0,96 & 0,97 & 2,39 \\
\hline $11,21 \mathrm{C}$ & $\mathrm{s} / \mathrm{KCl}$ & 0,88 & 1,01 & 2,48 \\
& $\mathrm{c} /$ & 0,96 & 0,87 & 2,14 \\
\hline $11,71 \mathrm{C}$ & $*$ & 0,96 & 0,17 & 0,42 \\
\hline
\end{tabular}

* A força iônica de $0,96 \mathrm{M}$ é atingida mesmo sem a adição do sal, devido ao $\mathrm{pH}$. Por este motivo, este ponto é incluído no gráfico "c/ KCl"

\section{Figura 6:}

Ensaio 6: Atividade da fosfatase alcalina em diferentes valores de $\mathrm{pH}$, em baixa e alta forças iônicas

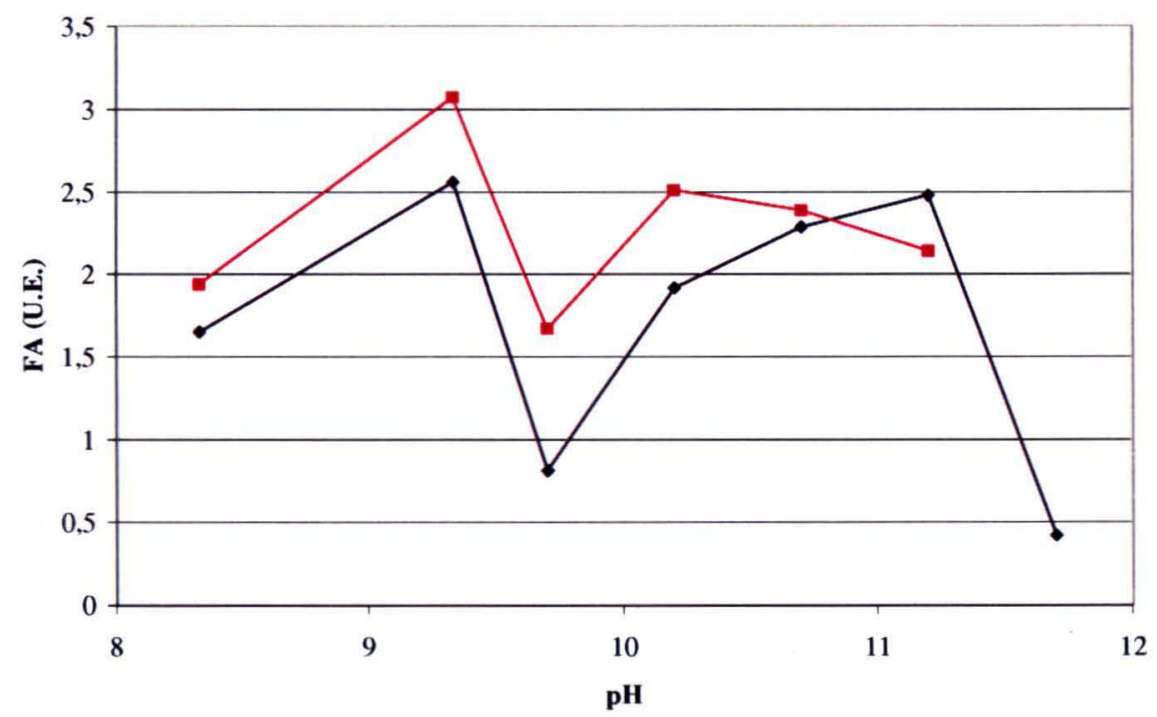

Em pH 11,71, a atividade foi $80 \%$ menor do que em $\mathrm{pH} 11,21$, na mesma força iônica $(0,96 \mathrm{M})$ e $83 \%$ menor em pH 11,21 e força iônica de $0,88 \mathrm{M}$. 
Comparando-se a atividade com e sem adição de $\mathrm{KCl}$, observou-se que esta foi maior na presença do sal. Somente em $\mathrm{pH} 11,21$, houve diminuição de $14 \%$ da atividade na presença de $\mathrm{KCl}$. 


\section{Ensaio 7:}

Tabela 8: Densidade óptica medida a $410 \mathrm{~nm}$ e atividade da Fosfatase Alcalina (FA) calculada a partir de ensaios realizados em diferentes pHs ajustados em função da temperatura de reação e da força iônica (FI).

\begin{tabular}{|c|c|c|c|}
\hline $\mathrm{pH}$ & $\mathrm{KCl}$ & $\mathrm{A}_{410}$ & $\mathrm{FA}$ \\
\hline $8,33 \mathrm{~T}$ & $\mathrm{~s} / \mathrm{KCl}$ & 1,02 & 17,60 \\
& $\mathrm{c} /$ & 1,12 & 19,30 \\
\hline $9,33 \mathrm{~T}$ & $\mathrm{~s} / \mathrm{KCl}$ & 1,29 & 22,24 \\
& $\mathrm{c} /$ & 1,43 & 24,65 \\
\hline $9,7 \mathrm{C}$ & $\mathrm{s} / \mathrm{KCl}$ & 0,47 & 8,10 \\
& $\mathrm{c} /$ & 0,88 & 15,17 \\
\hline $10,2 \mathrm{C}$ & $\mathrm{s} / \mathrm{KCl}$ & 0,94 & 16,21 \\
& $\mathrm{c} /$ & 0,96 & 16,55 \\
\hline $10,7 \mathrm{C}$ & $\mathrm{s} / \mathrm{KCl}$ & 1,01 & 17,41 \\
& $\mathrm{c} /$ & 1,17 & 20,17 \\
\hline $11,2 \mathrm{C}$ & $\mathrm{s} / \mathrm{KCl}$ & 0,71 & 12,24 \\
& $\mathrm{c} /$ & 0,71 & 12,24 \\
\hline $11,7 \mathrm{C}$ & $\mathrm{s} / \mathrm{KCl}$ & 0,10 & 1,81 \\
& & & \\
\hline
\end{tabular}

Figura 7:

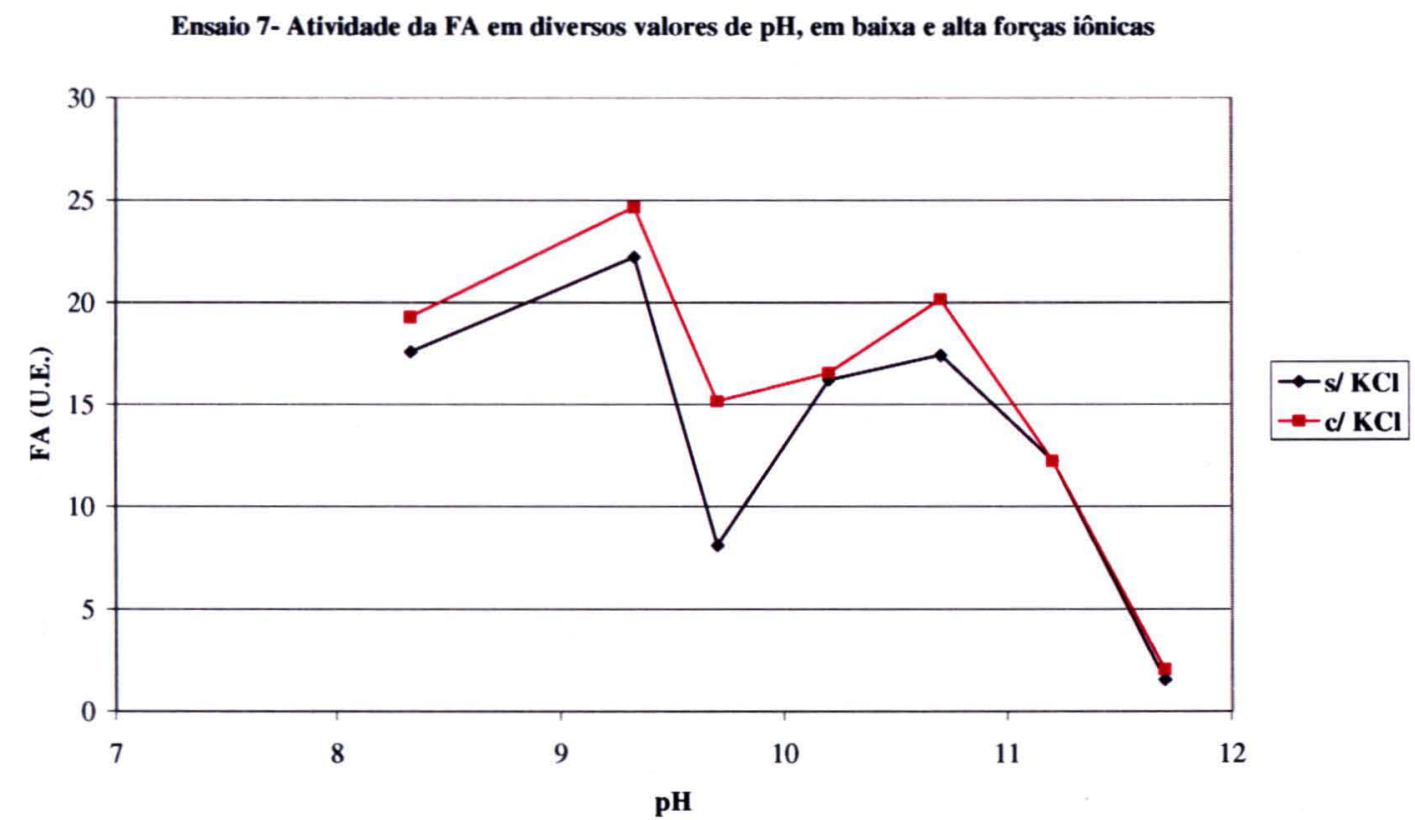

A atividade é aproximadamente $11 \%$ maior em alta força iônica para os valores de pH 8,33, 9,33 e 10,7. Em pH 9,7 esta é $87 \%$ maior em alta força iônica. A diferença não mais é observada em valores de $\mathrm{pH}$ acima de 11. 


\section{Ensaio 8:}

Tabela 9: Densidade óptica medida a $410 \mathrm{~nm}$ e atividade da Fosfatase Alcalina (FA) calculada a partir de ensaios realizados em diferentes valores de pH com as linhagens do tipo selvagem (wt) e BS 7, na presença e na ausência de Pi

\begin{tabular}{|c|c|c|c|c|}
\hline $\mathrm{pH}$ & $\mathrm{wt}-\mathrm{P}_{\mathrm{i}}$ & $\mathrm{wt}+\mathrm{P}_{\mathrm{i}}$ & $\mathrm{BS} 7$ & $\begin{array}{c}\mathrm{BS} 7+ \\
\mathrm{P}_{\mathrm{i}}\end{array}$ \\
\hline 8 & 1,11 & 0 & 1,2 & 0,015 \\
\hline 9 & 0,74 & 0 & 1,1 & 0 \\
\hline 10 & 0,42 & 0 & 0,57 & 0,013 \\
\hline 11 & 1,11 & 0 & 1,28 & 0,032 \\
\hline
\end{tabular}

Figura 8:

Ensaio 8: Atividade da fosfatase alcalina em diferentes valores de $\mathrm{pH}$

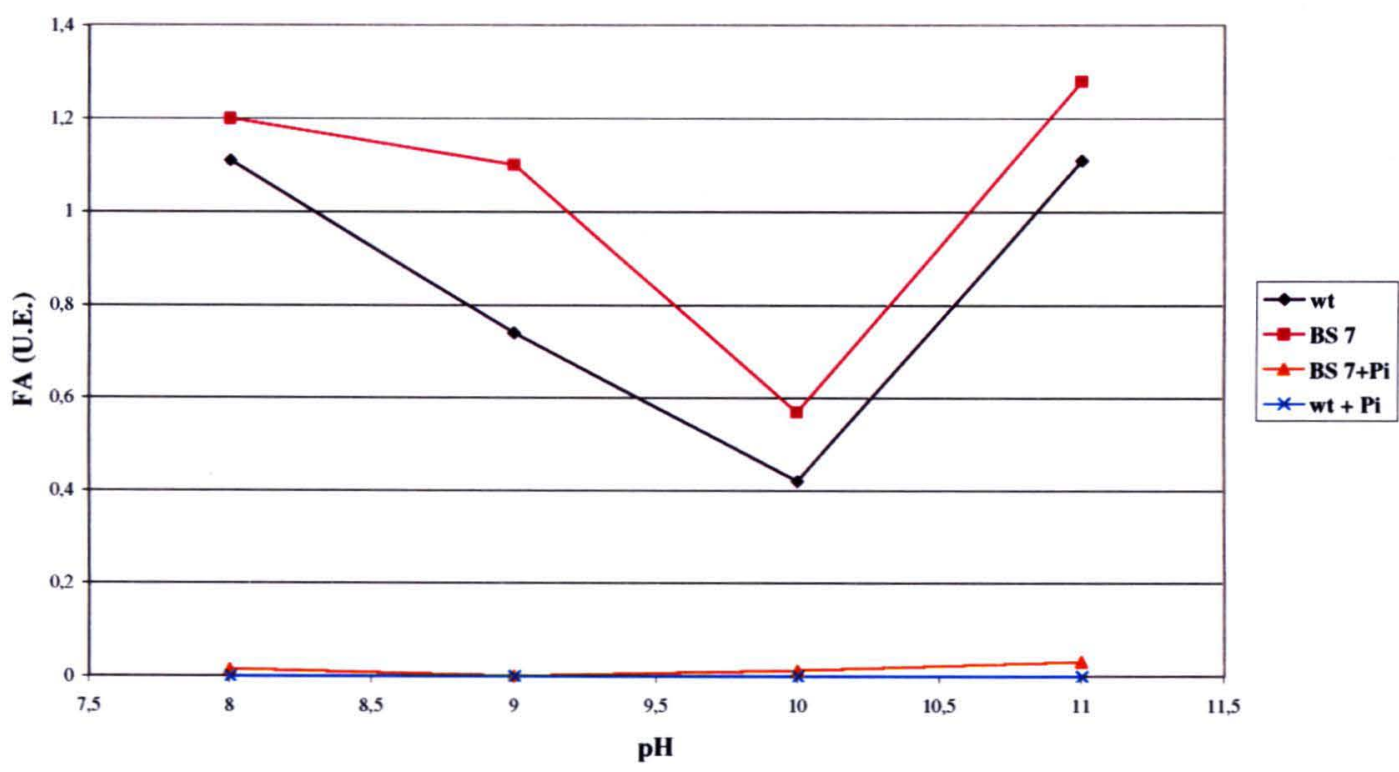

A linhagem wt, i.e., do tipo selvagem não expressou a enzima quando cultivada em presença de $P_{i}$ (Tabela 9, coluna 3). Obteve-se resultado inesperado, pois a linhagem BS 7, que expressa constitutivamente a enzima, deveria apresentar atividade, mas nenhuma atividade foi observada.

$\mathrm{O}$ resultado do teste rápido com $\alpha$-naftil fosfato/FAST BLUE indicou que a cultura da linhagem BS 7 mantida em meio sólido, a partir da qual eram feitos inóculos, estava expressando a fosfatase alcalina. 


\section{Ensaio 9:}

Tabela 10: Densidade óptica medida a $410 \mathrm{~nm}$ e atividade da Fosfatase Alcalina (FA) calculada a partir de ensaios realizados com as linhagens do tipo selvagem (wt) e BS 7, na presença e na ausência de Pi

\begin{tabular}{|c|c|c|c|c|}
\hline $\mathrm{pH}$ & $\mathrm{wt}-\mathrm{P}_{\mathrm{i}}$ & $\mathrm{wt}+\mathrm{P}_{\mathrm{i}}$ & $\begin{array}{c}\mathrm{BS} 7+ \\
\mathrm{P}_{\mathrm{i}}\end{array}$ & $\begin{array}{c}\mathrm{BS} 7- \\
\mathrm{P}_{\mathrm{i}}\end{array}$ \\
\hline 8 & 1,62 & 0,23 & 2,58 & 3,00 \\
\hline 9 & 1,62 & 0,18 & 2,64 & 2,69 \\
\hline 10 & 1,39 & 0,15 & 1,72 & 1,96 \\
\hline 11 & 3,57 & 0,21 & 3,75 & 4,30 \\
\hline
\end{tabular}

Figura 9:

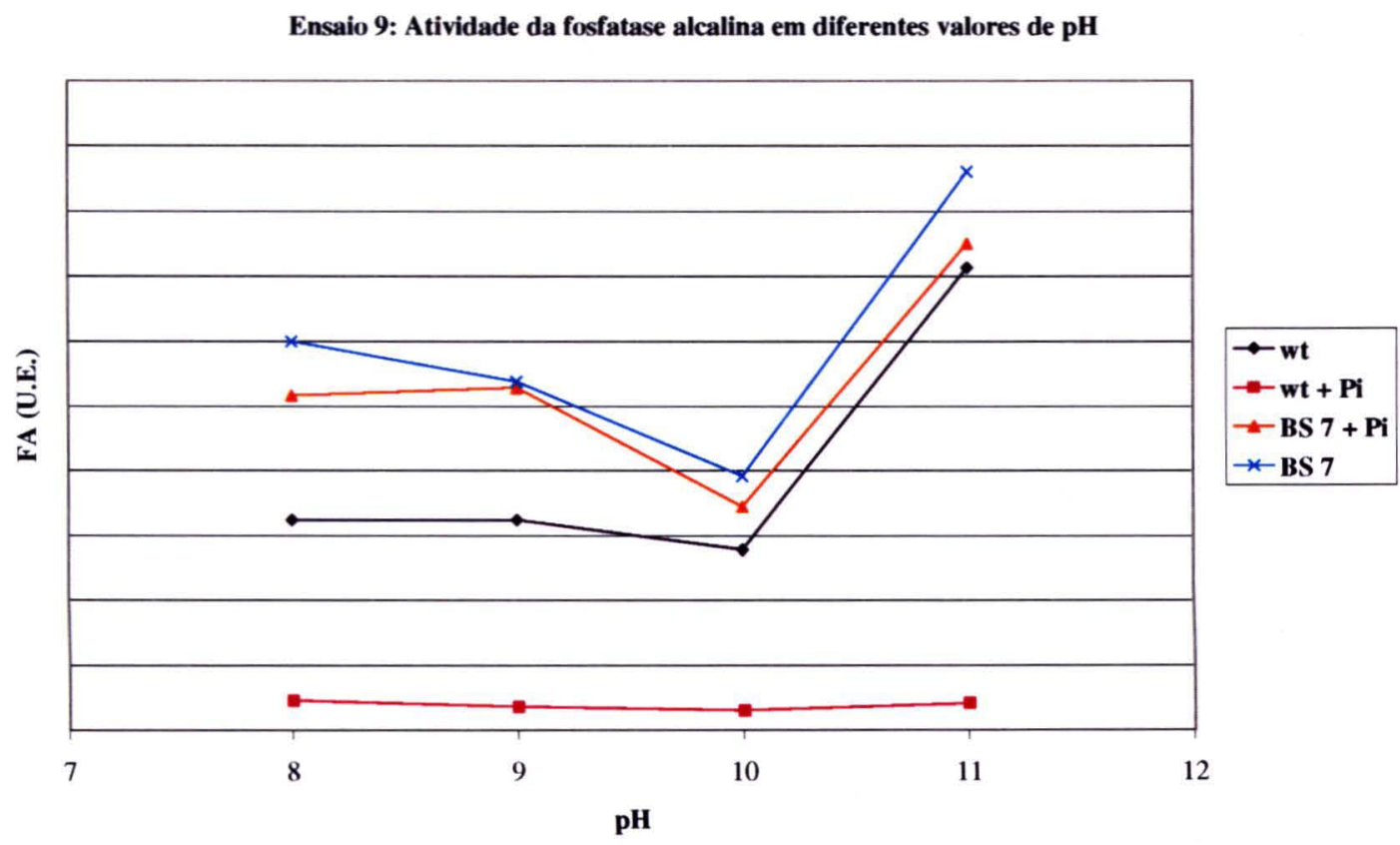

Não se observou atividade enzimática quando a bactéria do tipo selvagem foi cultivada em meio contendo fosfato. $\mathrm{Na}$ ausência de fosfato $\left(\mathrm{P}_{\mathrm{i}}\right)$, a enzima foi expressa e a atividade foi $120 \%$ maior em $\mathrm{pH} 11$ do que em $\mathrm{pH} 8$. O mesmo perfil foi obtido em ensaio com a linhagem BS 7, que expressa a enzima constitutivamente, porém observa-se maior atividade. Neste caso, tanto na presença quanto na ausência de $\mathrm{P}_{\mathrm{i}}$, a atividade foi $145 \%$ maior em $\mathrm{pH} 11$ do que em $\mathrm{pH} 8$. 


\section{Ensaio 10:}

Tabela 11: Densidade óptica medida a $410 \mathrm{~nm}$ e atividade da Fosfatase Alcalina (FA) calculada a partir de ensaios realizados em diferentes pHs ajustados em função da temperatura de reação e da força iônica (FI).

\begin{tabular}{|c|c|c|c|c|c|c|}
\hline $\mathrm{pH}$ & $\begin{array}{l}\text { wt }-\mathrm{Pi} \\
\text { Meio A }\end{array}$ & $\begin{array}{l}\mathrm{wt}+\mathrm{Pi} \\
\text { Meio A }\end{array}$ & $\begin{array}{l}\mathrm{wt}+\mathrm{Pi} \\
\mathrm{T} \text {-salts }\end{array}$ & $\begin{array}{l}\text { BS } 7 \text { - } \\
\mathrm{Pi} \\
\text { Meio A }\end{array}$ & $\begin{array}{l}\text { BS } 7+ \\
\text { Pi } \\
\text { Meio A }\end{array}$ & $\begin{array}{l}\text { BS } 7+ \\
\mathrm{Pi} \\
\text { T- salts }\end{array}$ \\
\hline 8 & 1,35 & 0,14 & 0,08 & 2,42 & 1,46 & 1,68 \\
\hline 9 & 1,5 & 0,93 & 0,07 & 2,81 & 1,38 & 1,26 \\
\hline 10 & 1 & 0,02 & 0,03 & 1,8 & 1,45 & 0,8 \\
\hline 11 & 2,9 & 0,01 & & 7,2 & 3,7 & 5,86 \\
\hline
\end{tabular}

Figura 10:

Ensaio 10: Atividade da fosfatase alcalina em diferentes valores de pH

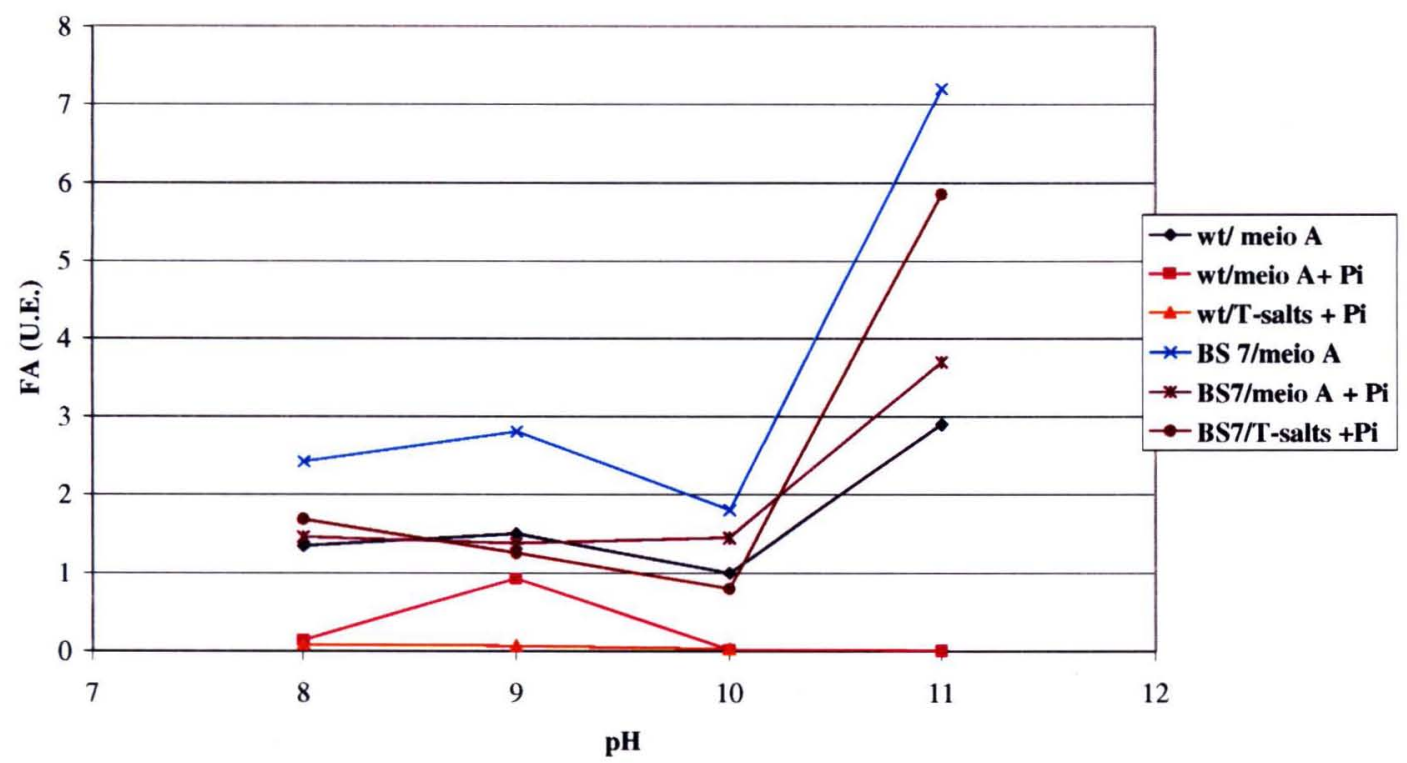


Não se observou atividade da fosfatase alcalina quando a linhagem do tipo selvagem (wt) foi cultivada em presença de Pi. Na ausência, a atividade foi $93 \%$ maior em pH 11 do que em pH 9.

Na linhagem BS 7, foi observada atividade em culturas cultivadas tanto no meio A, na presença e na ausência de Pi. Em T-salts só houve crescimento de ambas as linhagens na presença de $\mathrm{P}_{\mathrm{i}}$. Na linhagem BS 7, a atividade foi $250 \%$ maior em pH 11 do que em $\mathrm{pH}$ 8. A maior atividade foi observada em $\mathrm{pH} 11$, no ensaio realizado com BS7 cultivada em meio A, na ausência de $\mathrm{P}_{\mathrm{i}}$. Esta atividade foi $94 \%$ maior do que o ensaio realizado com amostras de BS 7 cultivadas em meio A, e $23 \%$ maior em T-salts, ambos na presença de $\mathrm{P}_{\mathrm{i}}$. 


\section{Ensaio 11:}

Tabela 12: Atividade da fosfatase alcalina calculada a partir de ensaios realizados em diferentes valores de pH, com as linhagens do tipo selvagem e BS 7, na presença e na ausência de Pi.

\begin{tabular}{|l|l|l|l|}
\hline $\mathrm{pH}$ & wt $-\mathrm{P}_{\mathrm{i}}$ & $\mathrm{BS} 7-\mathrm{P}_{\mathrm{i}}$ & $\mathrm{BS} 7+\mathrm{P}_{\mathrm{i}}$ \\
\hline 8 & 1,36 & 2,21 & 2,63 \\
\hline 9 & 1,59 & 2,86 & 2,78 \\
\hline 10 & 1,2 & 1,53 & 2,09 \\
\hline 11 & 3,94 & 6,42 & 7,28 \\
\hline
\end{tabular}

\section{Figura 11:}

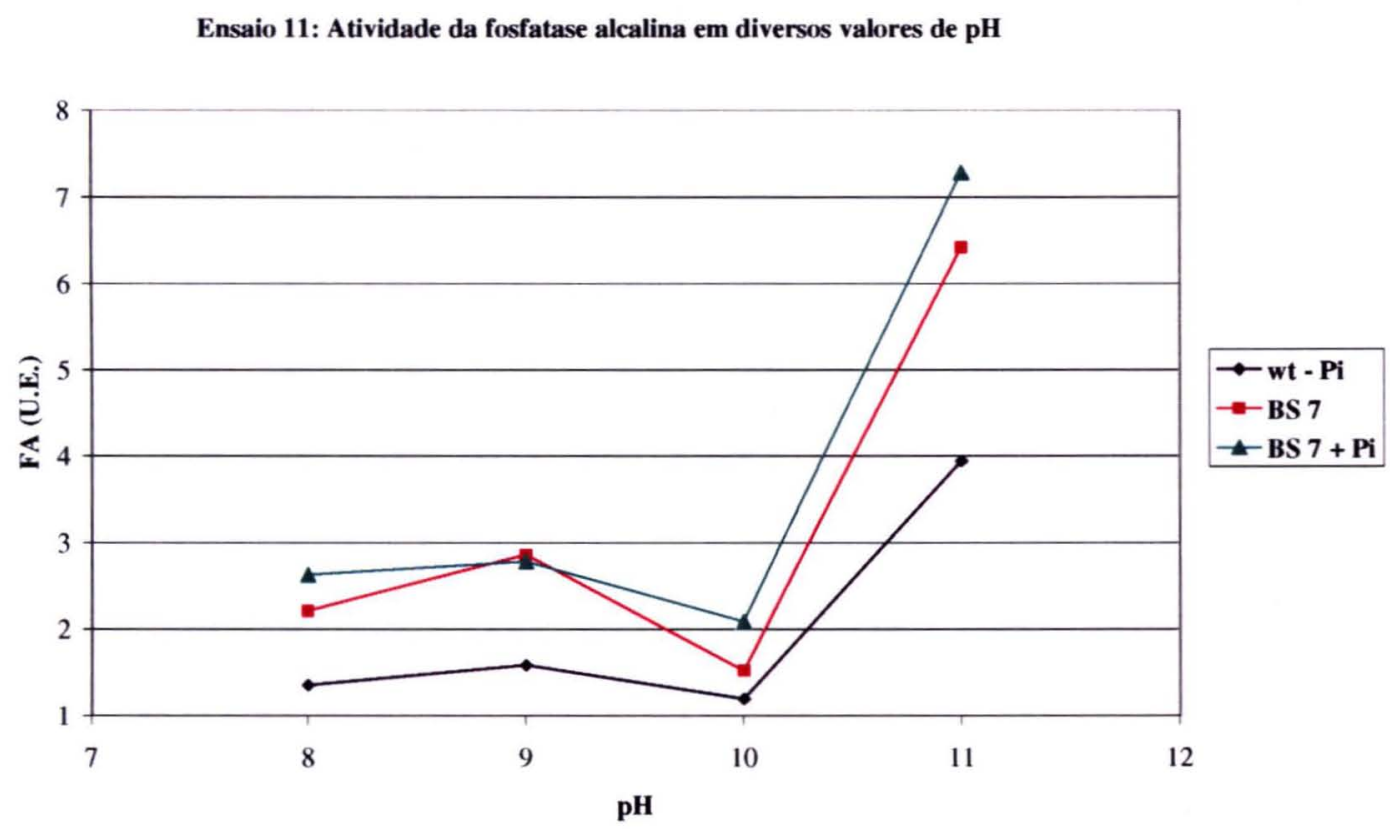

Na linhagem wt cultivada em ausência de $\mathrm{P}_{\mathrm{i}}$, a atividade enzimática foi $189 \%$ maior em $\mathrm{pH} 11$ do que em $\mathrm{pH} 8$ (2,89 vezes maior em $\mathrm{pH} 11)$. Na linhagem $\mathrm{BS} 7$, a diferença é de $190 \%$ na ausência e $176 \%$, na presença de fosfato.

Quando se comparam as atividades entre o pH 11 e 9, as diferenças são de $147 \%, 124 \%$ e $162 \%$ para a linhagem do tipo selvagem na ausência de fosfato, para a linhagem BS 7 na ausência e presença de fosfato, respectivamente.

A maior diferença de atividade observada foi de $190 \%$, entre a atividade em pH 11 e 8, no ensaio realizado com a linhagem BS 7 cultivada sem $P_{i}$. 


\section{Ensaio 12:}

Tabela 13: Atividade da fosfatase alcalina calculada a partir de ensaios realizados em diferentes valores de $\mathrm{pH}$, com bactéria E.coli linhagem BS 7, cultivada em meio A na presença ou ausência de Pi e em meio LB.

\begin{tabular}{|c|c|c|c|}
\hline $\mathrm{pH}$ & Meio A & $\begin{array}{c}\text { Meio A + } \\
\mathrm{Pi}\end{array}$ & LB \\
\hline 8 & 6,00 & 0,90 & 6,40 \\
\hline 9 & 3,90 & 0,10 & 5,20 \\
\hline 10 & -- & 0,00 & 3,18 \\
\hline 11 & 5,10 & -- & 6,59 \\
\hline
\end{tabular}

\section{Figura 12:}

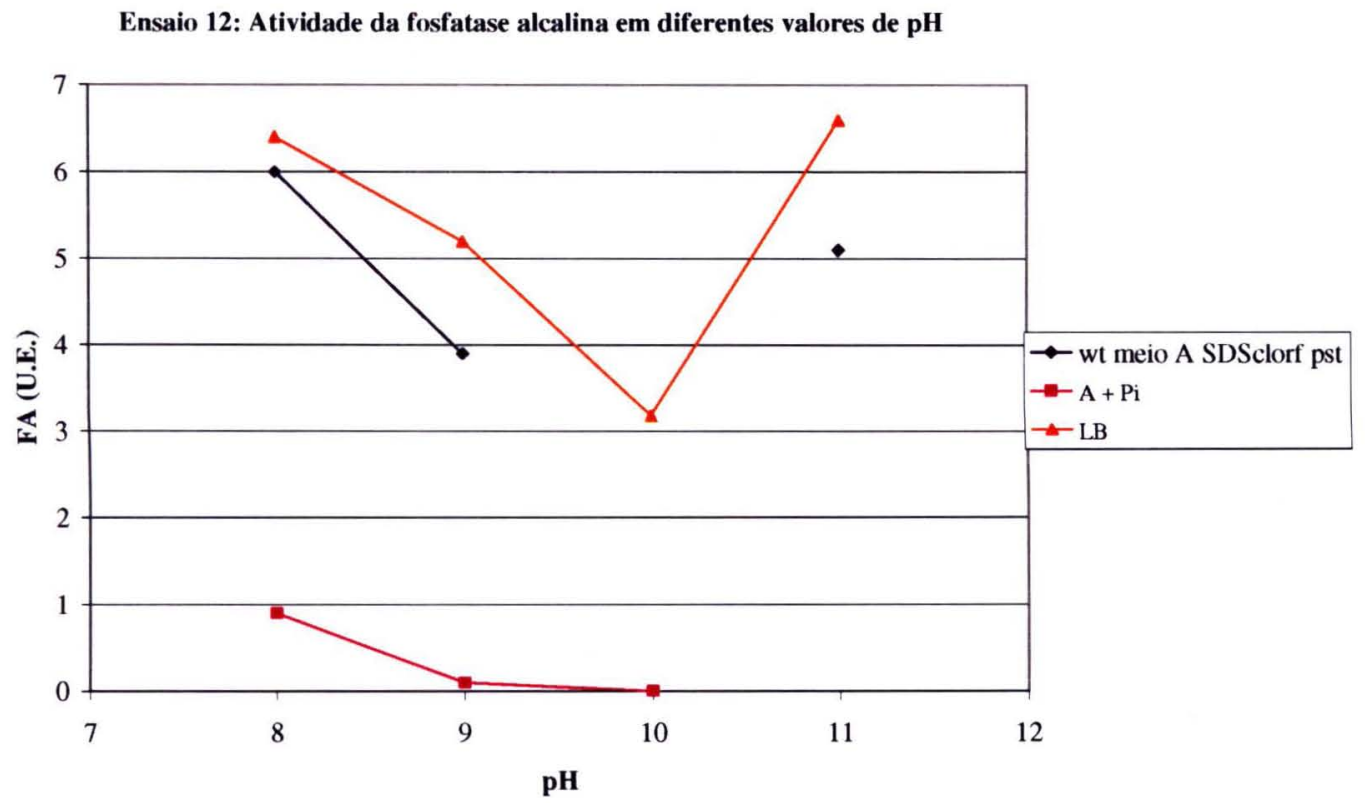

No experimento realizado com a linhagem do tipo selvagem cultivada em meio de cultura Meio A, a amostra correspondente ao $\mathrm{pH} 10$ foi perdida. A comparação entre o ponto referente ao $\mathrm{pH} 8$ e o pH 11, mostra que neste $\mathrm{pH}$ foram obtidas 1,18 vezes menos unidades de enzima.

Não foi possível realizar o ensaio em pH 11 com amostras cultivadas em meio A na presença de fosfato. 
Em ensaio utilizando a bactéria cultivada em meio LB,não houve diferença entre os valores de $\mathrm{pH} 11$ e 8 . A atividade em $\mathrm{pH} 11$ foi $27 \%$ maior que em $\mathrm{pH} 9$. 


\section{Ensaio 13:}

Tabela 14: Atividade da fosfatase alcalina observada na linhagem E.coli $\mathrm{BS} 7$ cultivada na presença e na ausência de $\mathrm{P}_{\mathrm{i}}$ em ensaios realizados em diferentes valores de $\mathrm{pH}$.

\begin{tabular}{|c|c|c|}
\hline $\mathrm{pH}$ & Meio A & Meio A + Pi \\
\hline 8 & 0,55 & 0,52 \\
\hline 9 & 0,75 & 0,94 \\
\hline 10 & 0,84 & 0,71 \\
\hline 11 & 0,37 & 0,71 \\
\hline
\end{tabular}

\section{Figura 13:}

Ensaio 13: Atividade da fosfatase alcalina em diferentes valores de pH

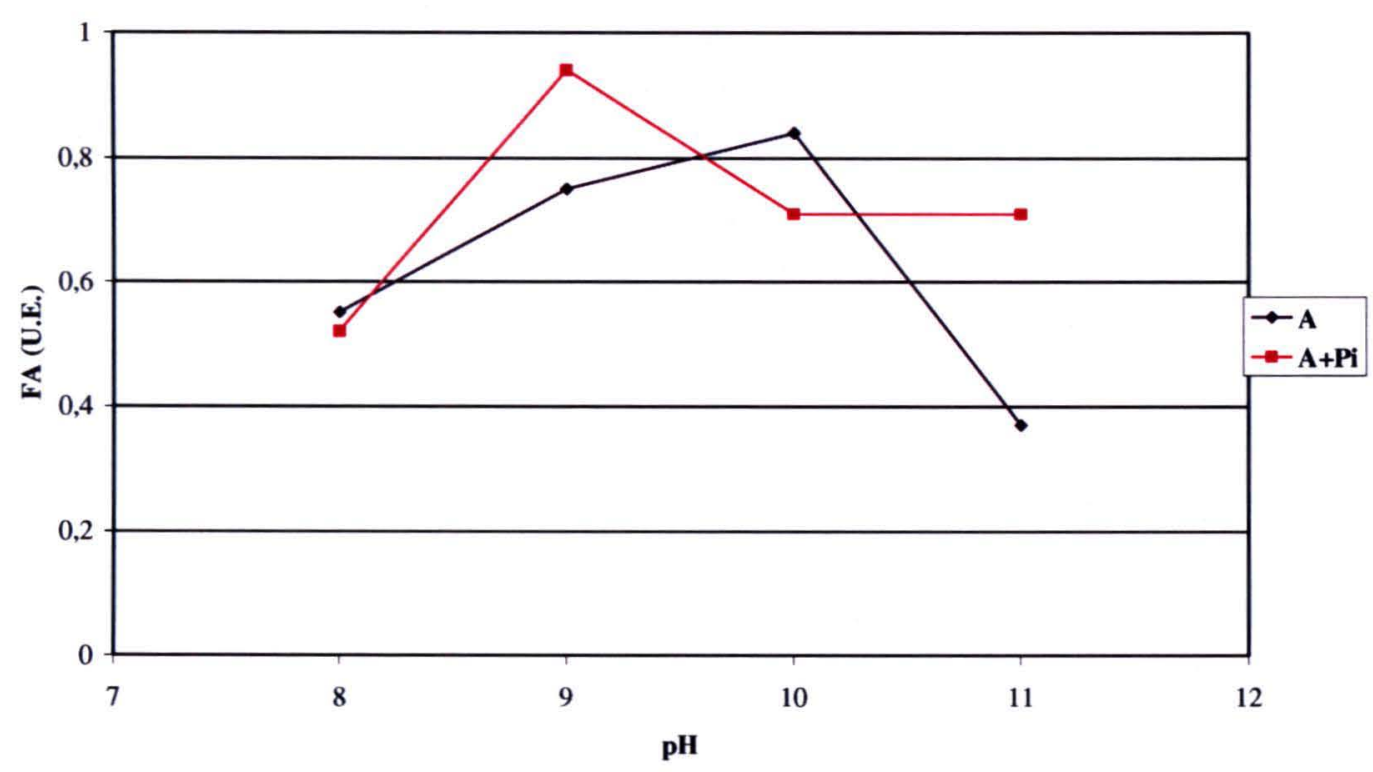

Em pH 8 não se observa diferença entre as duas condições de cultivo.

No cultivo em ausência de $\mathrm{P}_{\mathrm{i}}$, a atividade em $\mathrm{pH} 11$ foi $33 \%$ menor que em pH 8 e $51 \%$ menor que em pH 9.

Em pH 9 e 11, a atividade enzimática é $25 \%$ e $92 \%$ mais intensa no ensaio realizado com amostras de bactérias cultivadas na presença de fosfato $(\mathrm{Pi})$ do que a amostra cultivada na sua ausência. $\mathrm{O}$ resultado oposto é obtido em $\mathrm{pH} 10$, no qual a atividade é $18 \%$ maior na ausência de $\mathrm{P}_{\mathrm{i}}$. 


\section{Ensaio 14:}

Tabela 15: Atividade da fosfatase alcalina observada em ensaio realizado com a linhagem E.coli BS 7 cultivada em meio $A$, na ausência e na presença de $0,1 \mathrm{mM}$ e 1 mM de $P_{i}$.

\begin{tabular}{|c|c|c|c|}
\hline $\mathrm{pH}$ & A- Pi & $0,1 \mathrm{mM} \mathrm{Pi}$ & $1 \mathrm{mM}$ Pi \\
\hline 8 & 1,59 & 1,85 & 2,6 \\
\hline 9 & 2,28 & 1,79 & 2,93 \\
\hline 10 & 1,57 & 1,81 & 2,63 \\
\hline 11 & 2,53 & 3,00 & 1,87 \\
\hline
\end{tabular}

Figura 14:

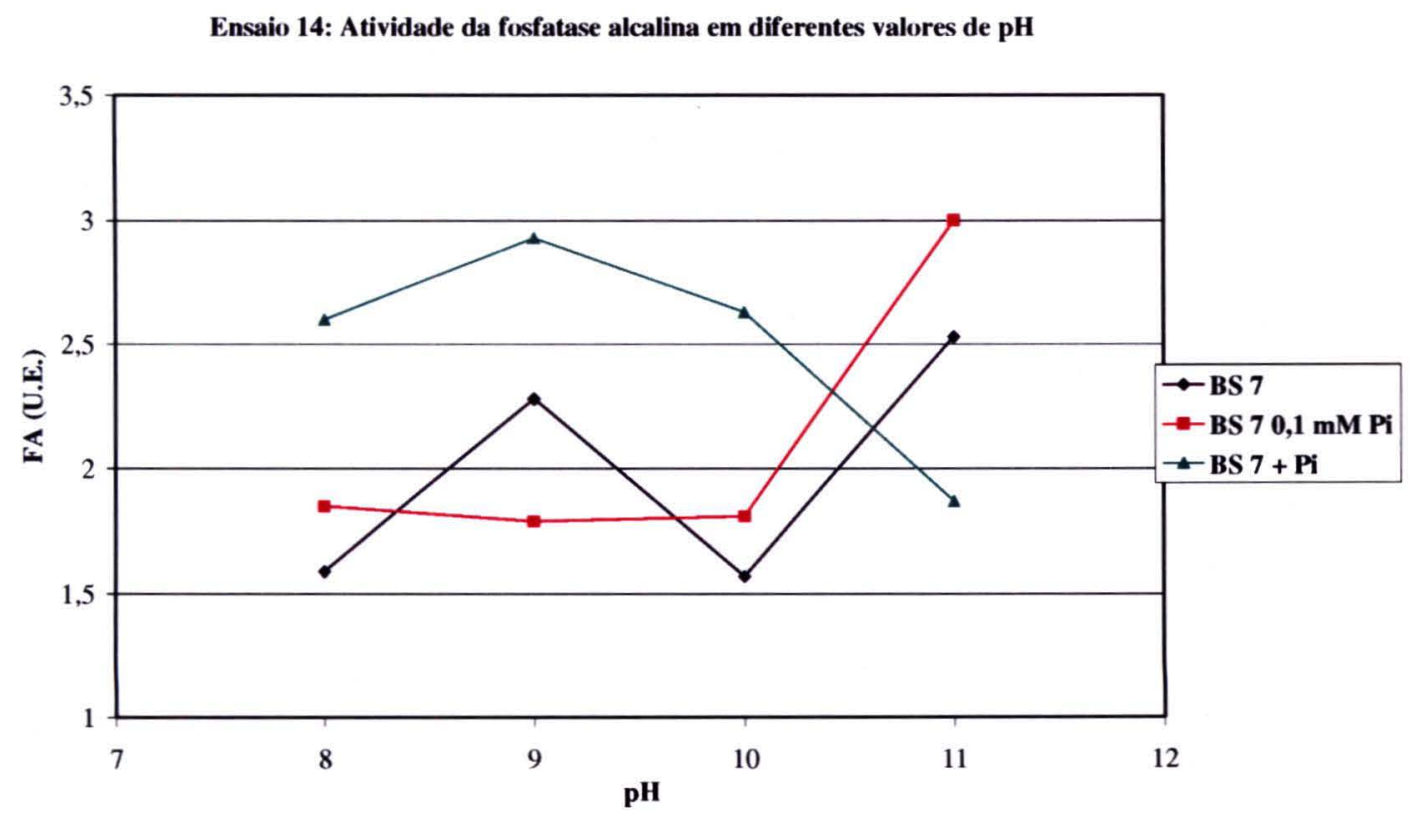

A atividade máxima é observada em pH 11, com medida realizada com bactéria cultivada em $0,1 \mathrm{mM} \mathrm{P}_{\mathrm{i}}$.

Em $1 \mathrm{mM} \mathrm{P}_{\mathrm{i}}$, a atividade máxima é observada em pH 9, caindo 1,57 vezes em pH 11 na qual é observada a menor atividade do ensaio. 


\section{Ensaio 15:}

Tabela 16: Atividade da fosfatase alcalina em ensaio realizado com a linhagem E.coli do tipo selvagem (wt) cultivada em meio A na ausência e na presença de $100 \mu \mathrm{M} \mathrm{e} 1 \mathrm{mM} \mathrm{P}_{\mathrm{b}}$, em pH variando de 8 a 11.

\begin{tabular}{|c|c|c|c|}
\hline $\mathrm{pH}$ & Meio A & $\begin{array}{c}\text { Meio A + } \\
0,1 \mathrm{mM} \mathrm{Pi}\end{array}$ & $\begin{array}{c}\text { Meio A + } \\
1 \mathrm{mM} \mathrm{Pi}\end{array}$ \\
\hline 8 & 1,73 & 0,66 & 0,05 \\
\hline 9 & 1,5 & 0,72 & 0,04 \\
\hline 10 & 1,8 & 0,92 & 0,03 \\
\hline 11 & 2,7 & 0,62 & 0,01 \\
\hline
\end{tabular}

Figura 15:

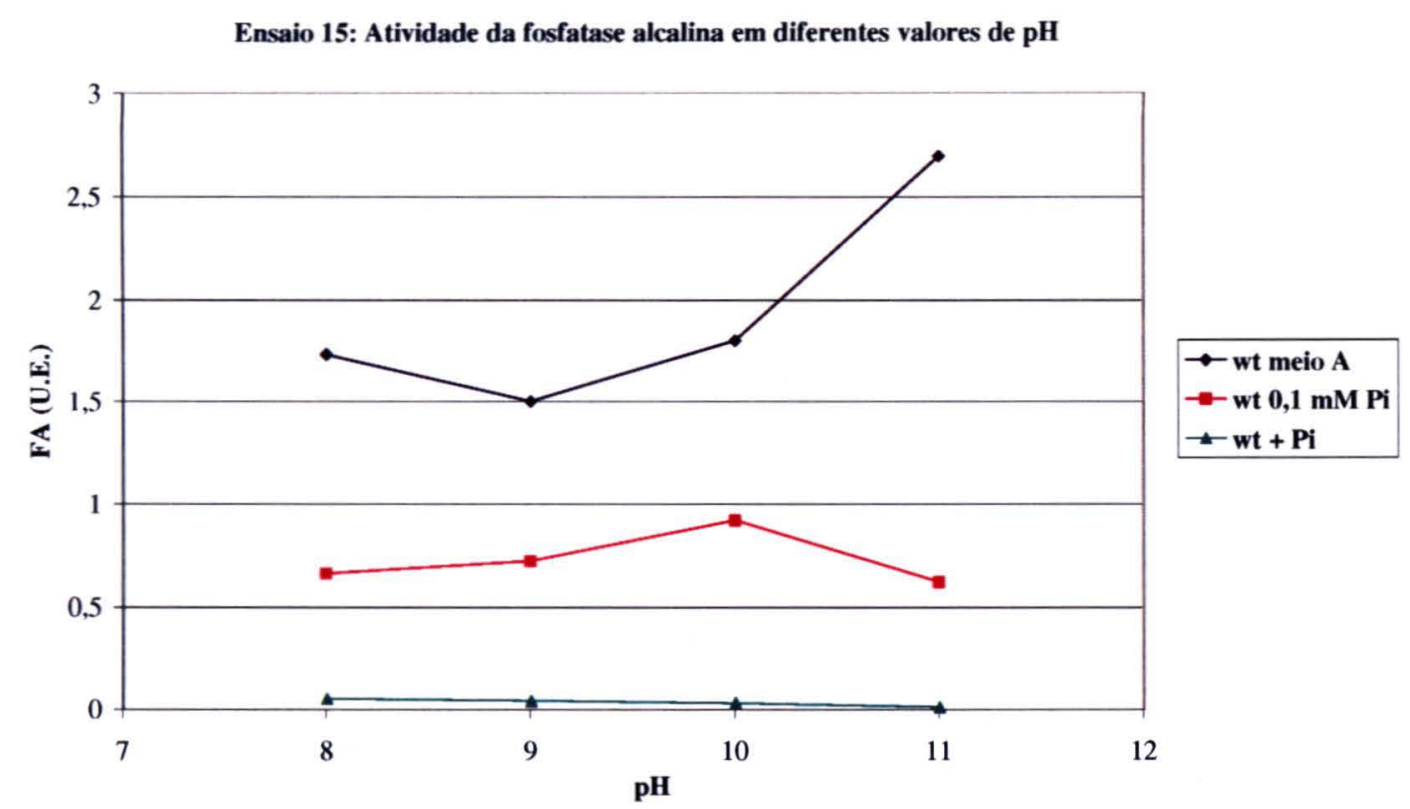

Na ausência de $\mathrm{P}_{\mathrm{i}}$, a atividade em pH 11 é 56\% mais intensa do que em pH 8. Comparando-se a atividade em condições de cultivo em $0,1 \mathrm{mM} \mathrm{P}_{\mathrm{i}}$, esta se mostrou ser $162 \%$ menor em pH 8 do que a atividade observada na ausência de $\mathrm{P}_{\mathrm{i}}$, e $110 \%$ menor em pH 9, $100 \%$ em pH 10 e $335 \%$ em pH 11, quando os valores são comparados ponto a ponto, i.e., no mesmo $\mathrm{pH}$, com aqueles obtidos na ausência de $\mathrm{P}_{\mathrm{i}}$. 
Como era de se esperar, na presença de $1 \mathrm{mM} \mathrm{P}_{\mathrm{i}}$ não se observou qualquer atividade da fosfatase alcalina. 


\section{Ensaio 16:}

Tabela 17: Atividade da fosfatase alcalina observada nas linhagens E.coli do tipo selvagem (wt) e BS 7, cultivadas em meio $A$ na ausência de $P_{i}$.

\begin{tabular}{|c|c|c|}
\hline $\mathrm{pH}$ & $\begin{array}{c}\text { Meio A - Pi } \\
\text { wt }\end{array}$ & $\begin{array}{c}\text { Meio A - Pi } \\
\text { BS 7 }\end{array}$ \\
\hline 8 & 1,75 & 2,70 \\
\hline 9 & 2,00 & 3,10 \\
\hline 10 & 1,35 & 2,00 \\
\hline 11 & 2,46 & 5,77 \\
\hline
\end{tabular}

Ensaio 16: Atividade da fosfatase alcalina em diferentes valores de pH

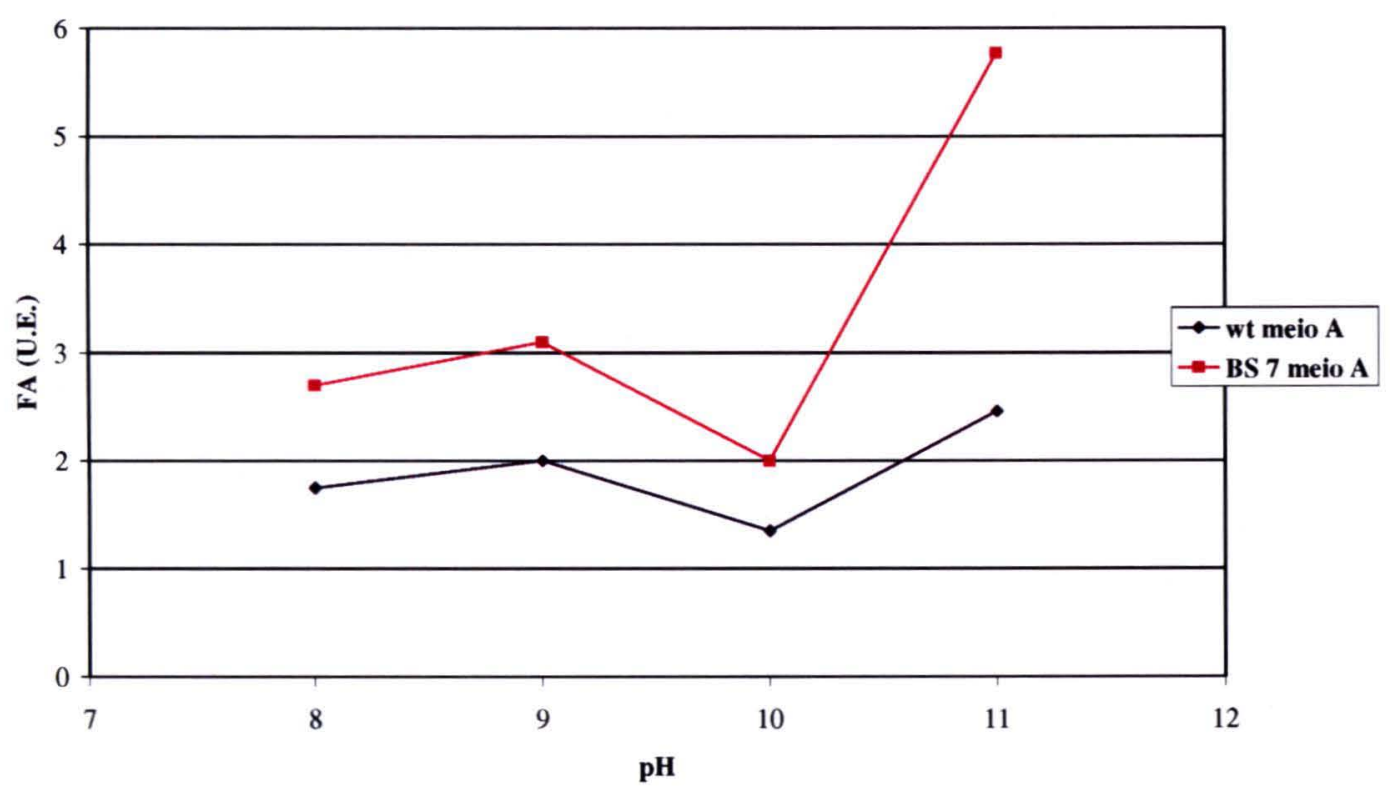

O perfil das curvas é o mesmo para as duas linhagens, porém a atividade é maior na linhagem BS 7. Em relação à wt, esta é $134 \%$ maior em pH 11,54\% em pH 8 e $55 \%$ em pH 9.

$\mathrm{Na}$ linhagem BS 7, a atividade em pH 11 é 113\% maior do que em $\mathrm{pH} 8$ e $86 \%$ maior do que em $\mathrm{pH} 9$.

No wt, a atividade em pH 11 é $40 \%$ maior que em $\mathrm{pH} 8$ e $23 \%$ maior que em pH 9. 


\section{Ensaio 17:}

Tabela 18: Atividade da fosfatase alcalina (FA) resultante de ensaios realizados com as linhagens E.coli do tipo selvagem (wt) e BS 7, cultivadas em meio $A$ na presença e ausência de $P_{\mathfrak{r}}$.

\begin{tabular}{|c|c|c|c|}
\hline $\mathrm{pH}$ & $\begin{array}{c}\text { wt } \\
\text { Meio A + } \\
\mathrm{Pi}\end{array}$ & $\begin{array}{c}\text { BS 7 } \\
\text { Meio A - } \\
\mathrm{Pi}\end{array}$ & $\begin{array}{c}\text { BS 7 Meio } \\
\mathrm{A}+\mathrm{Pi}\end{array}$ \\
\hline 8 & 0,05 & 5,60 & 4,10 \\
\hline 9 & 0,07 & 5,50 & 4,45 \\
\hline 10 & 0,06 & 3,20 & 3,09 \\
\hline 11 & 0,00 & 11,40 & 7,37 \\
\hline
\end{tabular}

Ensaio 17: Atividade da fosfatase alcalina em diferentes valores de $\mathrm{pH}$

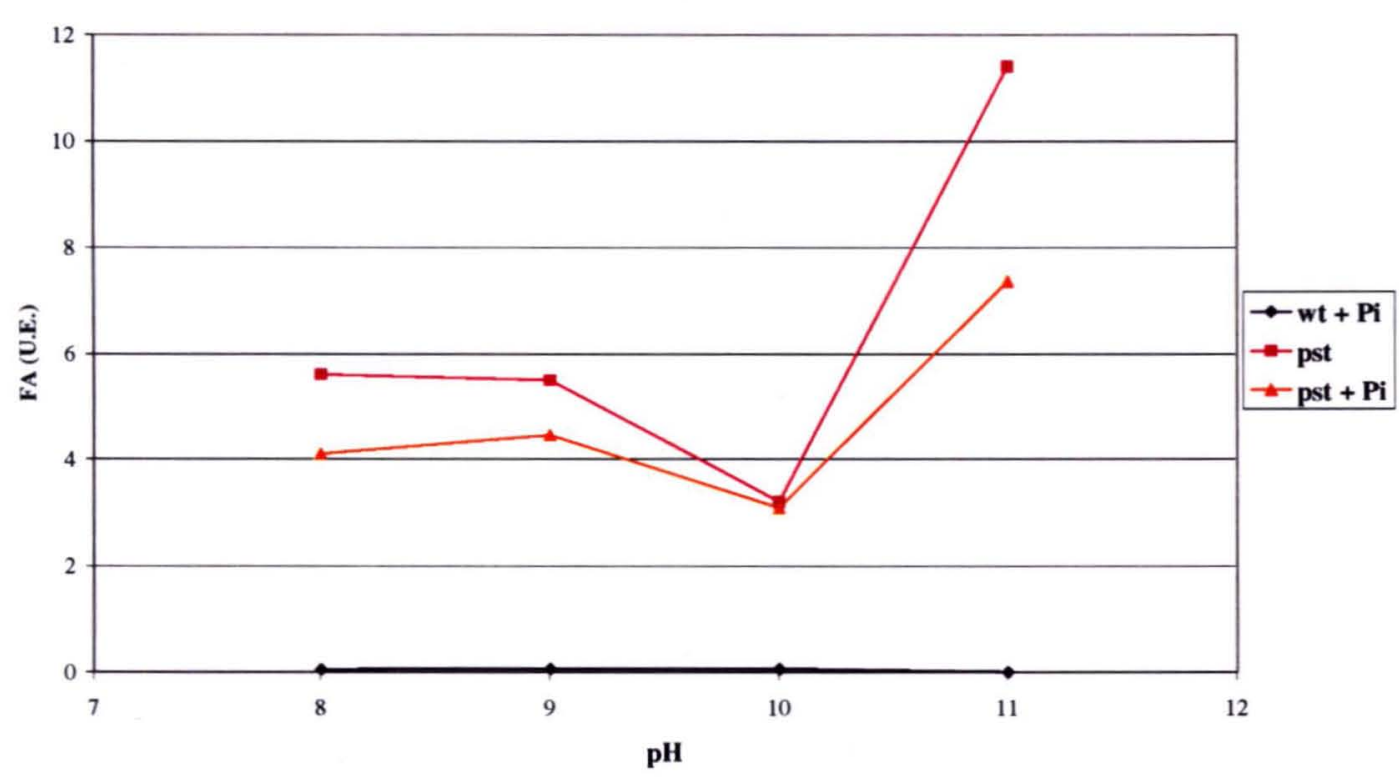

Não houve atividade detectável de fosfatase alcalina quando a linhagem wt foi crescida na presença de $P_{i}$.

Em $\mathrm{pH} 11$, a atividade foi $55 \%$ maior no ensaio realizado com a bactéria cultivada na ausência de $P_{i}$, do que aquela crescida na presença de $P_{i}$.

A atividade foi $103 \%$ maior em $\mathrm{pH} 11$ do que em $\mathrm{pH} 8 \mathrm{e} 107 \%$ maior do que em pH 9, nos ensaios com a bactéria crescida na ausência de $\mathrm{P}_{\mathrm{i}}$.

A atividade foi $80 \%$ maior em $\mathrm{pH} 11$ do que em $\mathrm{pH} 8$ e $66 \%$ maior do que em pH 9, nos ensaios com a bactéria crescida na presença de $\mathrm{P}_{\mathrm{i}}$. 


\section{Ensaio 18:}

Tabela 19: Atividade da fosfatase alcalina (FA) calculada a partir de ensaios realizados em diferentes valores de pH, com as linhagens E.coli wt e BS 7, na presença e ausência de $P_{i}$.

\begin{tabular}{|c|c|c|c|}
\hline $\mathrm{pH}$ & wt- Pi & wt + Pi & BS 7 - Pi \\
\hline 8 & 1,30 & 0,04 & 2,40 \\
\hline 9 & 1,50 & 0,02 & 0,95 \\
\hline 10 & 0,95 & 0,00 & 1,80 \\
\hline 11 & 3,30 & 0,02 & 2,80 \\
\hline
\end{tabular}

Figura 18:

Ensaio 18: Atividade da fosfatase alcalina em diferentes valores de $\mathrm{pH}$

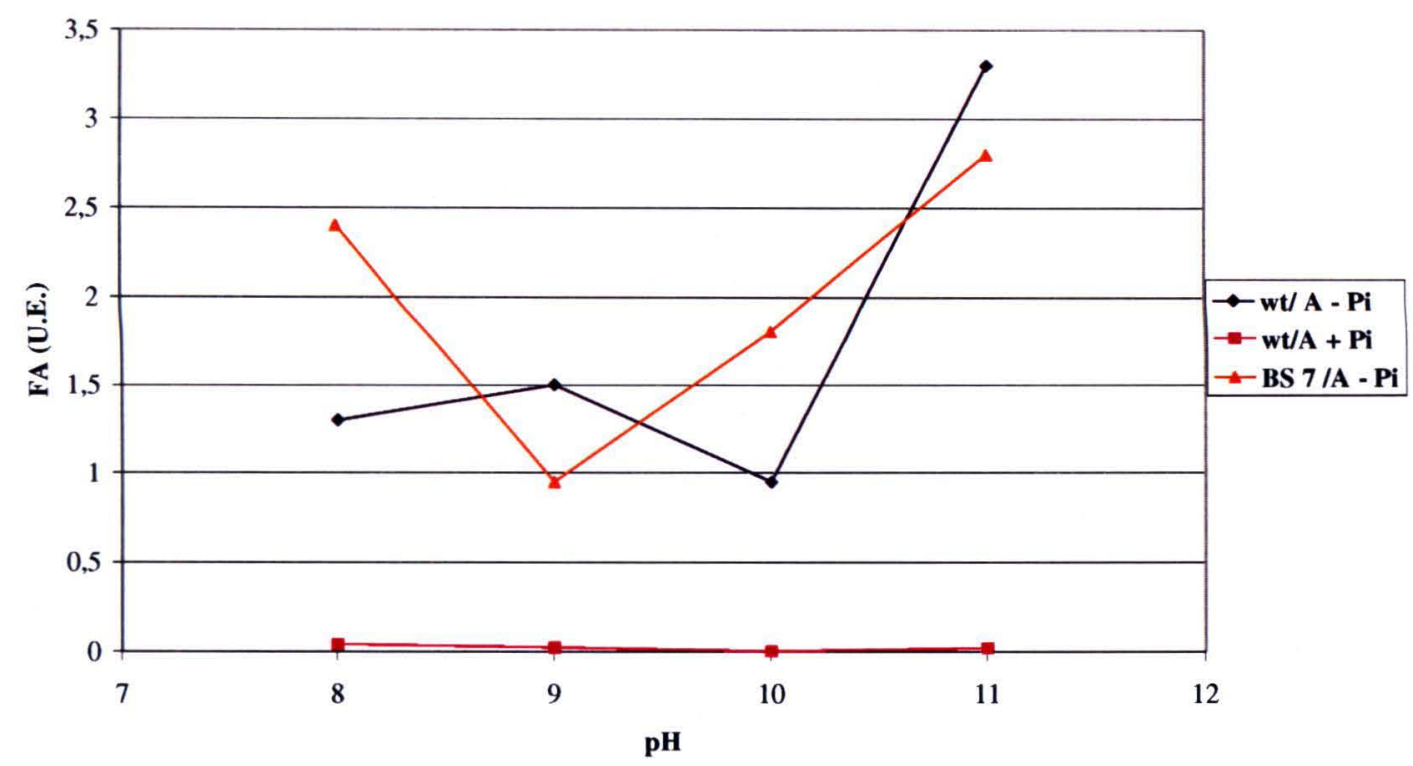

No ensaio realizado com a bactéria do tipo selvagem wt cultivada na presença de fosfato, não se observa atividade da fosfatase alcalina. A amostra cultivada na ausência de fosfato apresentou atividade enzimática $150 \%$ maior em $\mathrm{pH} 11$ do que em pH 8.

A linhagem BS 7, cultivada na ausência de $P_{i}$ apresentou atividade $16 \%$ maior em pH 11 do que em pH 8 e $195 \%$ que em pH 9.

Neste experimento, não houve crescimento da cultura da linhagem BS 7 incubada em presença de $\mathrm{P}_{\mathrm{i}}$. 


\section{Ensaio 19:}

Tabela 20: Atividade da fosfatase alcalina (FA) calculada a partir de ensaios realizados em diferentes valores de pH com a linhagem da bactéria E.coli BS 7 cultivada em três meios de cultura: meio A com e sem Pi, T-salts com Pi e LB.

\begin{tabular}{|c|c|c|c|c|}
\hline $\mathrm{pH}$ & $\mathrm{T}-\mathrm{s}+\mathrm{Pi}$ & $\mathrm{A}-\mathrm{Pi}$ & $\mathrm{A}+\mathrm{Pi}$ & $\mathrm{LB}$ \\
\hline 8 & 2,73 & 2,50 & 2,18 & 3,22 \\
\hline 9 & 2,94 & 1,94 & 2,00 & 2,86 \\
\hline 10 & 2,67 & 2,12 & 1,65 & 2,75 \\
\hline 11 & 6,65 & 5,63 & 5,83 & 5,65 \\
\hline
\end{tabular}

Figura 19:

Ensaio 19: Atividade da fosfatase alcalina em diferentes valores de $\mathrm{pH}$

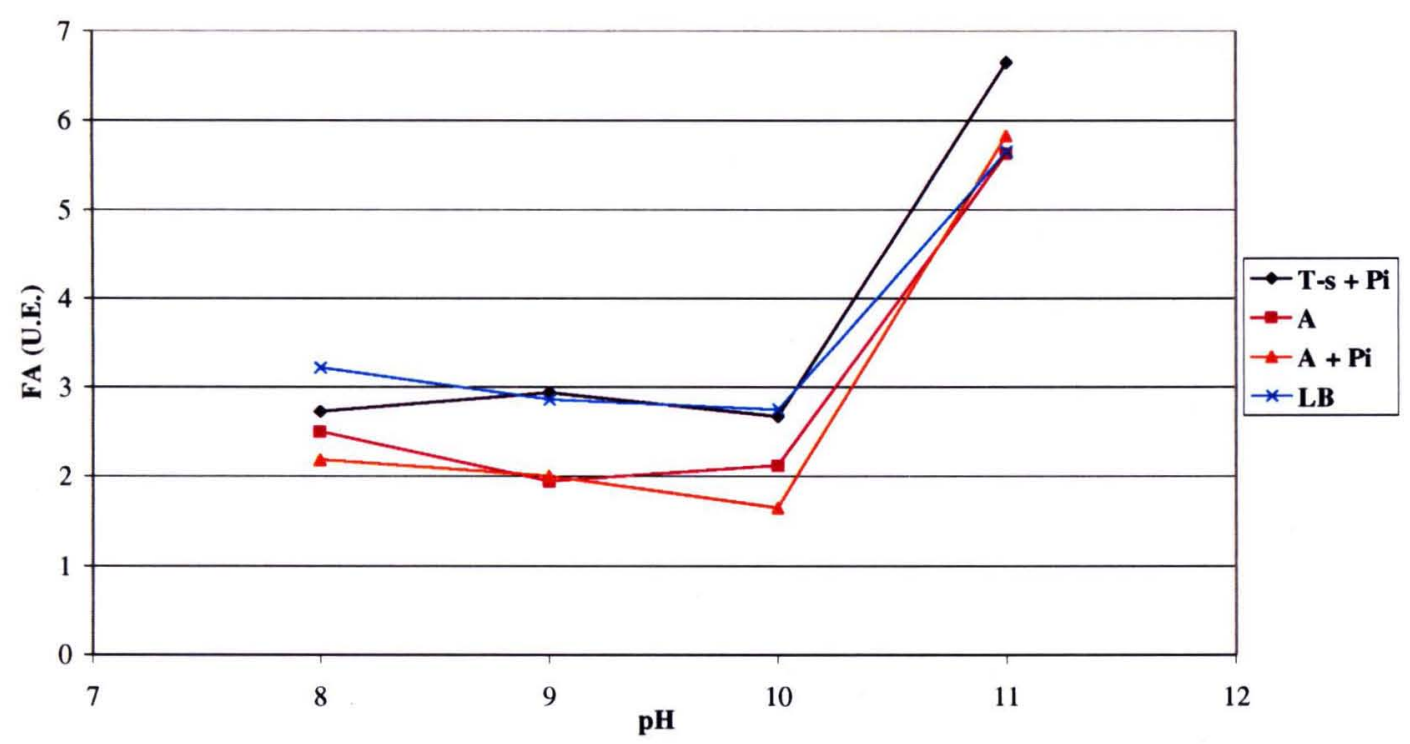

Todos os resultados apresentam o mesmo perfil de atividade. Em todos os resultados obtidos, observou-se aumento na intensidade da reação em pH 11, em relação ao pH 8 e 9. Quando comparados os valores de pH 11 e 8 entre si, a atividade foi $144 \%$ maior no ensaio realizado com bactérias cultivadas em T-salts na presença de $\mathrm{P}_{\mathrm{i}}, 125 \%$ maior em meio A na ausência de $\mathrm{Pi}, 167 \%$ em meio A na presença de $\mathrm{Pi}$ e $75 \%$ para LB.

A atividade foi $126 \%, 190 \%, 191 \%$ e $98 \%$ maior em $\mathrm{pH} 11$ do que em $\mathrm{pH} 9$, seguindo a mesma sequiência de condições de cultivo acima descrita. 


\section{Ensaio 20:}

Tabela 21: Atividade da fosfatase alcalina (FA) calculada a partir de ensaios realizados com a linhagem de bactéria E.coli wt e BS 7, cultivadas em meio de cultura A, na ausência de Pi

\begin{tabular}{|c|c|c|}
\hline $\mathrm{pH}$ & wt & BS 7 \\
\hline 8 & 1,50 & 2,70 \\
\hline 9 & 1,90 & 2,97 \\
\hline 10 & 1,80 & 2,94 \\
\hline 11 & 3,80 & 6,30 \\
\hline
\end{tabular}

Figura 20:

Ensaio 20: Atividade da fosfatase alcalina em diferentes valores de pH

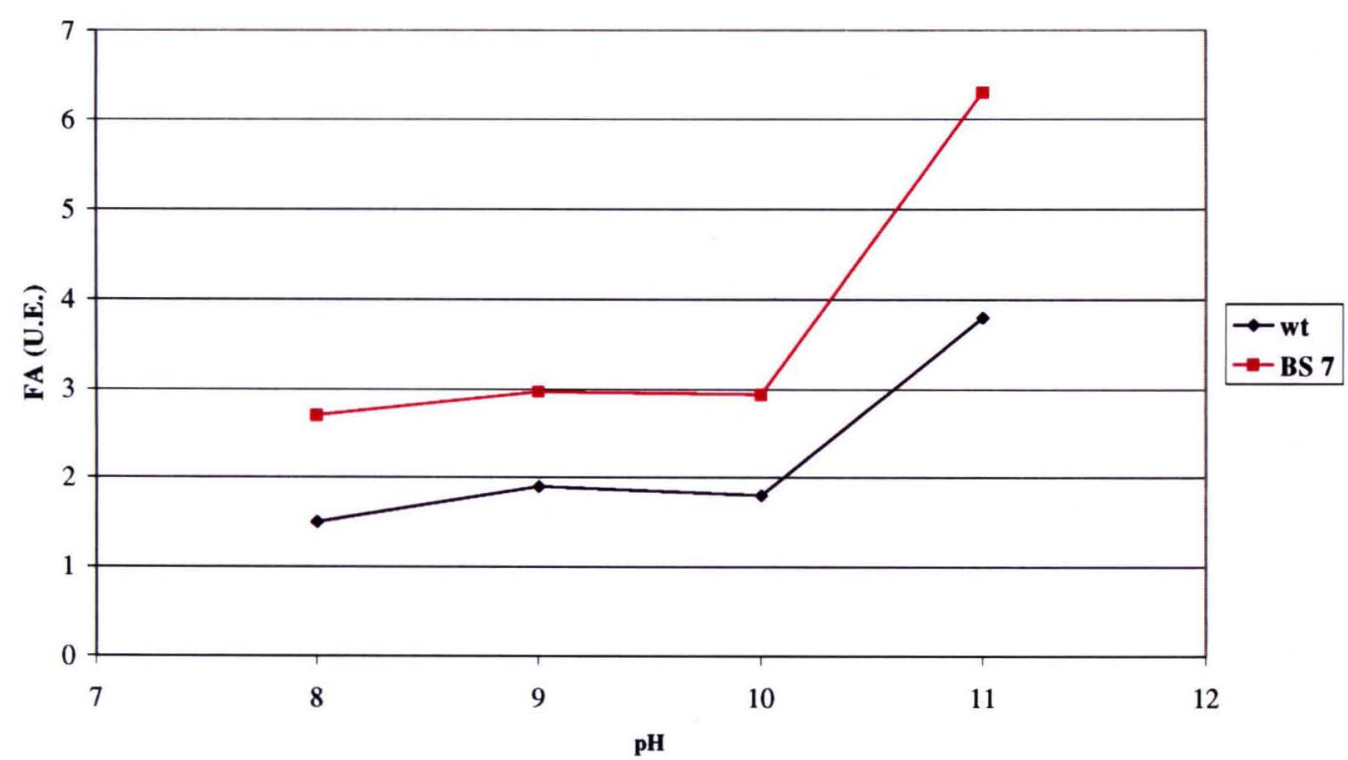

Ambas as curvas apresentam o mesmo perfil. Em ambas, a atividade em $\mathrm{pH}$ 11 foi maior.Na linhagem wt, a atividade é na média $66 \%$ menor.

A diferença na atividade enzimática em $\mathrm{pH} 11$ e 8 foi de $153 \%$ para wt e de $133 \%$ para BS 7.

A atividade observada em $\mathrm{pH} 11$ foi $100 \%$ maior do que em $\mathrm{pH} 9$ na linhagem wt e $112 \%$ maior na BS 7. 


\section{Ensaio 21:}

Tabela 22: Atividade de fosfatase alcalina calculada a partir de ensaios realizados em valores de pH variando de 8 a 11, com as linhagens de bactéria E. coli do tipo selvagem (wt), BS 7 e rpo $S$, cultivadas em meio de cultura meio A - Pi.

\begin{tabular}{|c|c|c|c|}
\hline $\mathrm{pH}$ & $\begin{array}{c}\text { wt } \\
\mathrm{A}-\mathrm{P}_{\mathrm{i}}\end{array}$ & $\begin{array}{c}\text { BS 7 } \\
\mathrm{A}-\mathrm{P}_{\mathrm{i}}\end{array}$ & $\begin{array}{c}\text { rpo S } \\
\mathrm{A}-\mathrm{P}_{\mathrm{i}}\end{array}$ \\
\hline 8 & 1,40 & 2,40 & 3,20 \\
\hline 9 & 1,50 & 2,80 & 3,90 \\
\hline 10 & 1,20 & 2,00 & 2,60 \\
\hline 11 & 3,00 & 5,80 & 10,60 \\
\hline
\end{tabular}

Figura 21:

Ensaio 21: Atividade da fosfatase alcalina em diferentes valores de $\mathrm{pH}$

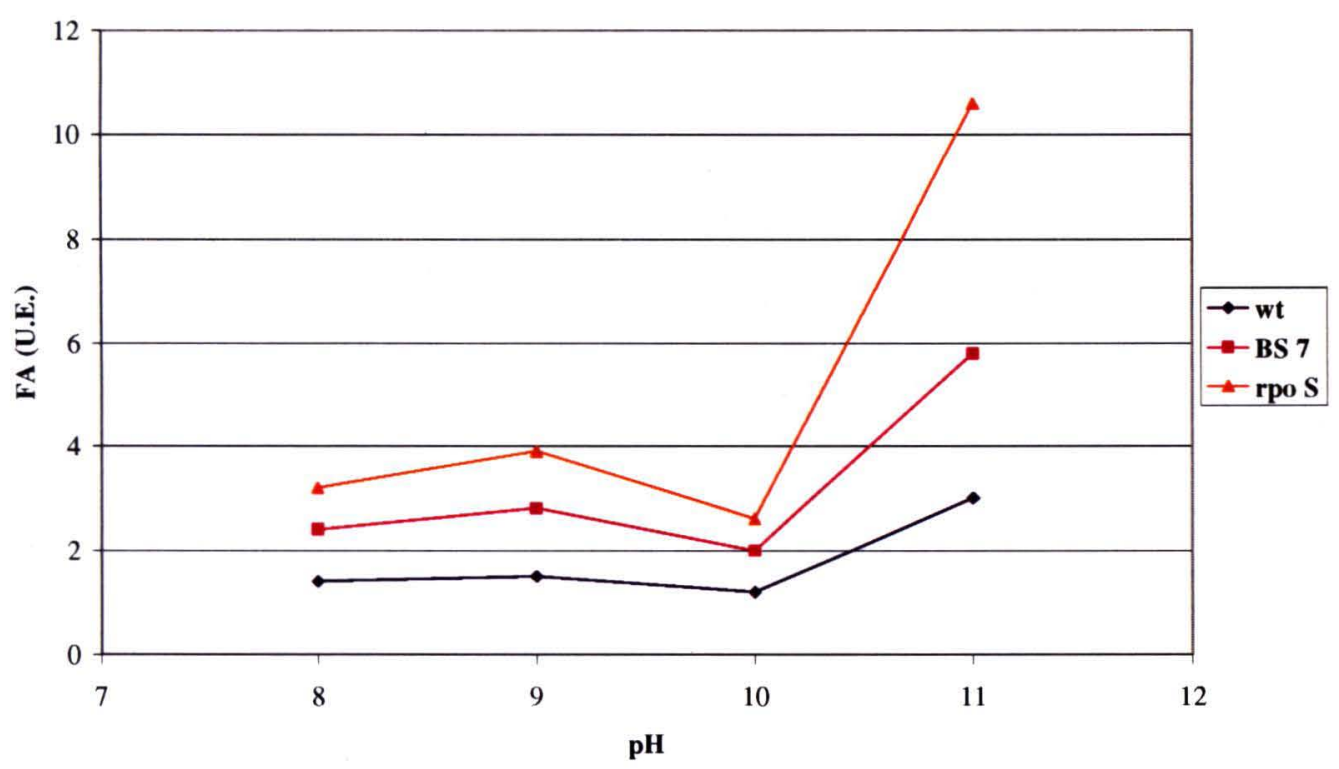

Em todos os casos, a atividade foi mais intensa em $\mathrm{pH} 11$ do que em $\mathrm{pH} 8 \mathrm{e}$ pH 9. Em pH 11, a atividade foi $114 \%$ maior na wt, $141 \%$ maior na BS 7 e $230 \%$ maior na rpo $S$ quando comparada ao $\mathrm{pH}$ 8. Quando comparada ao $\mathrm{pH} \mathrm{9,} \mathrm{a} \mathrm{atividade}$ foi $100 \%, 107 \%$ e $171 \%$ maior na wt,BS 7 e rpo $S$, respectivamente.

Em média, a atividade foi $46 \%$ maior nos ensaios realizados com a linhagem rpo $S$, quando comparada à linhagem BS 7 e $163 \%$ maior quando comparada à wt. As reações com a BS 7, foram por sua vez em média, 1,79 vez mais intensas do que aquelas obtidas com a wt. 
TABELA 23: RAZÃO ENTRE OS VALORES DA ATIVIDADE ENZIMÁTICA EM pH 11 E pH 8 OU pH 11 e pH 9.

\begin{tabular}{|c|c|c|c|c|c|c|c|}
\hline \multirow{2}{*}{$\begin{array}{c}\mathbf{N}^{\circ} \\
\text { ENSAIO }\end{array}$} & \multirow{2}{*}{$\begin{array}{l}\text { MEIO de } \\
\text { CULTURA }\end{array}$} & \multicolumn{3}{|c|}{$\begin{array}{l}\text { RAZÃO ENTRE pH 11/8 } \\
\text { (vide Figura 22) } *^{1}\end{array}$} & \multicolumn{3}{|c|}{$\begin{array}{c}\text { RAZÃO ENTRE pH 11/9 } \\
\left(\text { vide Figura 23) } *^{2}\right. \\
\end{array}$} \\
\hline & & wt & BS7 & rpoS & wt & BS7 & rpoS \\
\hline 1 & LB & & $1,7_{(1)}$ & & & $1,27_{(1)}$ & \\
\hline 2 & $\begin{array}{l}\text { T-salts } \\
\text { LB }\end{array}$ & & $\begin{array}{l}1,57_{(2)} \\
0,51_{(3)}\end{array}$ & & & $\begin{array}{l}1,7_{(2)} \\
0,55_{(3)}\end{array}$ & \\
\hline 3 & LB & & $0,68_{(4)}$ & & & $0,56_{(4)}$ & \\
\hline 8 & $\mathbf{A}$ & $1,00_{(5)}$ & $1,06_{(6)}$ & & $1,5_{(5)}$ & $1,16_{(6)}$ & \\
\hline 9 & $\begin{array}{l}\mathbf{A} \\
\mathbf{A}+\mathbf{P i}\end{array}$ & $2,2(7)$ & $\begin{array}{l}1,45_{(8)} \\
1,43_{(9)}\end{array}$ & & $2,2_{(7)}$ & $\begin{array}{l}1,42_{(8)} \\
1,60_{(9)}\end{array}$ & \\
\hline 10 & \begin{tabular}{|l|}
$\mathbf{A}$ \\
$\mathbf{A}+\mathbf{P}_{\mathbf{i}}$ \\
$\mathbf{T}$-salts+P \\
\end{tabular} & $2,14_{(10)}$ & $\begin{array}{l}2,93_{(11)} \\
2,53_{(12)} \\
3,49_{(13)}\end{array}$ & & $1,93_{(10)}$ & $\begin{array}{l}2,56_{(11)} \\
2,68_{(12)}\end{array}$ & \\
\hline 11 & $\begin{array}{l}\mathbf{A} \\
\mathbf{A}+\mathbf{P i}\end{array}$ & $2,90_{(14)}$ & $\begin{array}{l}2,90_{(15)} \\
2,77_{(16)}\end{array}$ & & $2,48_{(14)}$ & $\begin{array}{l}2,24_{(15)} \\
2,62_{(16)}\end{array}$ & \\
\hline 12 & \begin{tabular}{|l|}
$\mathbf{A}$ \\
$\mathbf{L B}$ \\
\end{tabular} & & $\begin{array}{l}0,85_{(17)} \\
1,03_{(18)}\end{array}$ & & & $\begin{array}{l}1,30_{(17)} \\
1,27_{(18)}\end{array}$ & \\
\hline 13 & \begin{tabular}{|l|}
$\mathbf{A}$ \\
$\mathbf{A}+\mathbf{P i}$ \\
\end{tabular} & & $\begin{array}{l}0,67_{(19)} \\
1,36_{(20)}\end{array}$ & & & $\begin{array}{l}0,49_{(19)} \\
0,75_{(20)}\end{array}$ & \\
\hline 14 & $\begin{array}{l}A \\
A+0,1 \mathbf{m M ~ P}_{\mathbf{i}} \\
\mathrm{A}+1 \mathrm{mMP}_{\mathrm{i}}\end{array}$ & & $\begin{array}{l}1,59_{(21)} \\
1,62_{(22)} \\
0,71_{(23)}\end{array}$ & & & $\begin{array}{l}1,10_{(21)} \\
1,68_{(22)} \\
0,64_{(23)}\end{array}$ & \\
\hline \multirow[t]{3}{*}{15} & \multirow{3}{*}{$\begin{array}{l}A \\
A+0,1 \mathrm{mM} \mathrm{P}_{\mathrm{i}} \\
\mathrm{A}+1 \mathrm{mMP}_{\mathrm{i}}\end{array}$} & $1,56_{(24)}$ & & & $1,8_{(24)}$ & & \\
\hline & & & & & $0,86_{(25)}$ & & \\
\hline & & s/ativd & & & s/ativd & & \\
\hline 16 & $\mathbf{A}$ & $1,4_{(26)}$ & $2,13_{(27)}$ & & $1,23_{(26)}$ & $1,86_{(27)}$ & \\
\hline 17 & \begin{tabular}{|l|}
$\mathbf{A}$ \\
$\mathbf{A}+\mathbf{P}_{\mathbf{i}}$ \\
\end{tabular} & s/ativd & $\begin{array}{l}2,04_{(28)} \\
1,80_{(29)}\end{array}$ & & & $\begin{array}{l}2,07_{(28)} \\
1,66_{(29)}\end{array}$ & \\
\hline 18 & $\begin{array}{l}\mathbf{A} \\
\mathbf{A}+\mathbf{P}_{\mathbf{i}}\end{array}$ & $\begin{array}{l}2,54_{(30)} \\
\text { s/ativd }\end{array}$ & $1,17_{(31)}$ & & $2,20_{(30)}$ & $2,95_{(31)}$ & \\
\hline 19 & $\begin{array}{l}\mathbf{A} \\
\mathbf{A}+\mathbf{P}_{\mathbf{i}} \\
\mathbf{T}-\mathbf{s a l t s}+\mathbf{P}_{\mathbf{i}} \\
\mathbf{L B}\end{array}$ & & $\begin{array}{l}2,25_{(32)} \\
2,67_{(33)} \\
2,44_{(34)} \\
1,75_{(35)}\end{array}$ & & & $\begin{array}{l}2,90_{(32)} \\
2,91_{(33)} \\
2,26_{(34)} \\
1,97_{(35)}\end{array}$ & \\
\hline 20 & A & $2,53_{(36)}$ & $2,33_{(37)}$ & & $2,00_{(36)}$ & $2,12_{(37)}$ & \\
\hline 21 & $\mathbf{A}$ & $2,14_{(38)}$ & $2,42_{(39)}$ & & $2,00_{(38)}$ & $2,07_{(39)}$ & $2,72_{(40)}$ \\
\hline
\end{tabular}

*1 RAZÃO ENTRE pH 11/8= VALOR DA ATIVIDADE DA FOSFATASE ALCALINA EM pH 11 VALOR DA ATIVIDADE DA FOSFATASE ALCALINA EM pH 8 $*^{2}$ como $*^{1}$, mas ENTRE pH 11 e pH 9

Os números em subescritos em parênteses correspondem às barras das Figuras 22 e 23 e resumem as condições experimentais.

As cores correspondem às linhagens bacterianas.Verde: wt; amarelo e laranja: BS7; azul: rpo S. As tonalidades brilhantes correspondem à razão entre pH11/8 e os tons pastéis entre pH 11/9. As cores laranja e turquesa correspondem a razões $<1$. 
FIGURA 22:

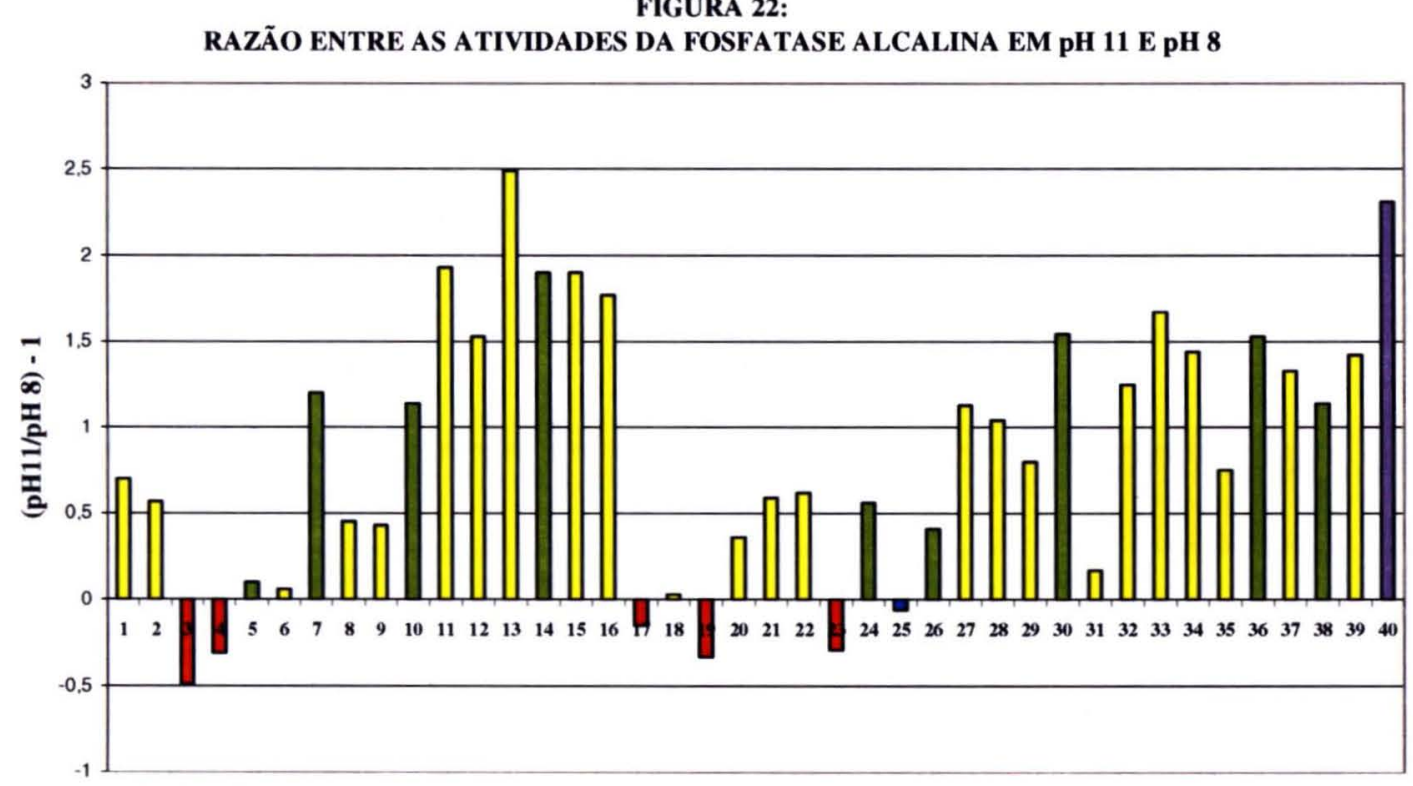

No DA CONDIÇÃO DE ENSAIO

FIGURA 23:

RAZÃO ENTRE AS ATIVIDADES DA FOSFATASE ALCALINA EM pH 11 E pH 9

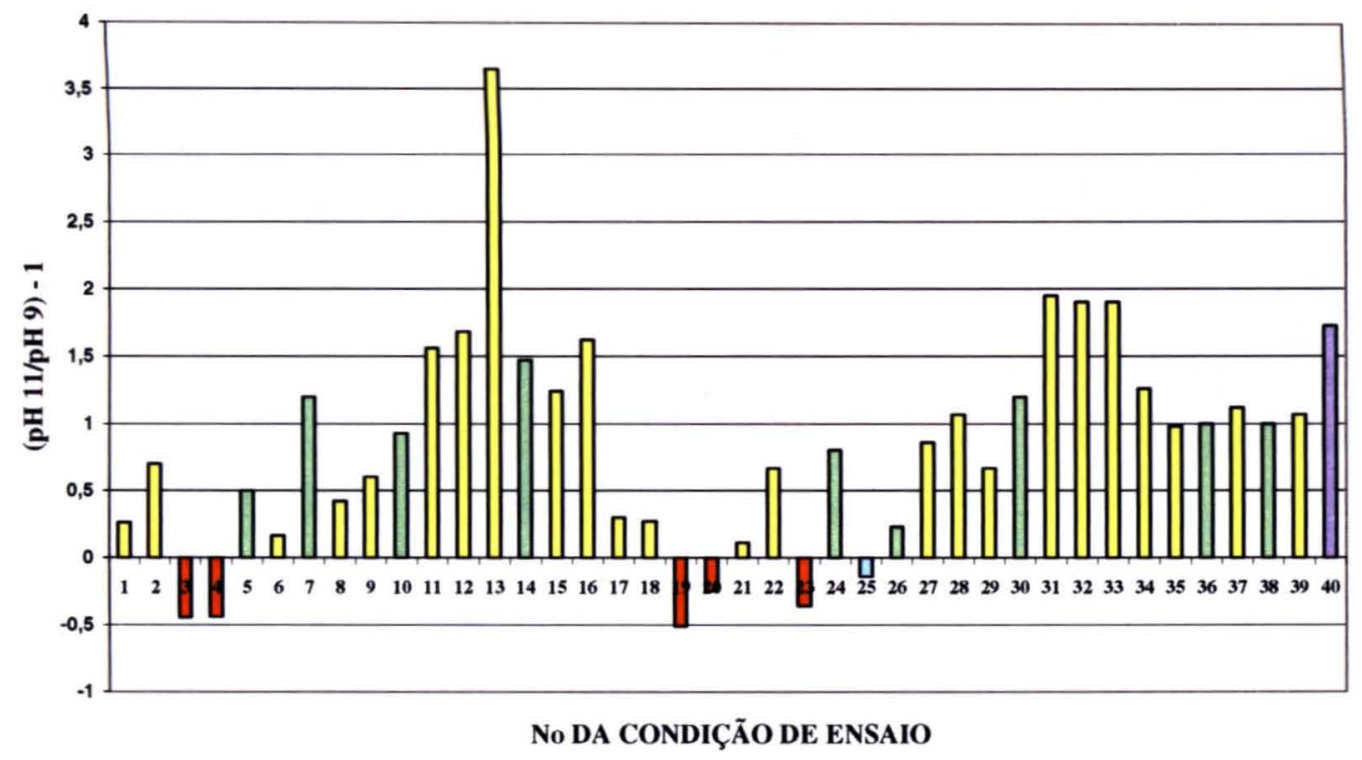

\section{Legenda:}

Abcissa: condição experimental (vide legenda da tabela 23)

Ordenada: [Razão entre os valores das atividades da fosfatase alcalina em pH 11e pH 8 (Fig 22) ou em pH 11 e pH 9 (Fig 23)] - 1

Cores das Barras : Razão > 1: Verde: linhagem wt; Amarelo: BS 7; Azul: rpo S

Razão < 1: Laranja: BS 7; Turquesa: wt.

Tonalidades brilhantes e pastéis: Razão 11/8 e Razão 11/9, respectivamente. 
TABELA 24: RAZÃO ENTRE OS VALORES DA ATIVIDADE DA FOSFATASE ALCALINA EM pH 11 E pH 8

(ENSAIOS REALIZADOS COM CORREÇÃO DE VALOR ENTRE A TEMPERATURA DE PREPARO DA SOLUÇÃO E A TEMPERATURA DE ENSAIO e COM FORÇA IÔNICA CONTROLADA)

\begin{tabular}{|c|c|c|c|c|c|}
\hline \multirow{2}{*}{$\begin{array}{c}\mathbf{N}^{\mathbf{o}} \\
\text { ENSAIO }\end{array}$} & \multirow{2}{*}{$\begin{array}{l}\text { FORÇA } \\
\text { IÔNICA }\end{array}$} & \multicolumn{2}{|c|}{$\underset{\text { (vide FIGURA 24) }}{\text { RAZÃO ENTRE }}$} & \multicolumn{2}{|c|}{$\underset{\text { (vide FIGURA 25) }}{\text { RAZÑO ENTRE pH }}$} \\
\hline & & $10,8 / 8,33$ & $11,4 / 8,33$ & $10,8 / 9,33$ & $11,4 / 9,33$ \\
\hline 3 & $\begin{array}{c}\text { S/AD } \\
\text { KCl }\end{array}$ & & & $\begin{array}{c}1,04 \\
(1)\end{array}$ & $\begin{array}{l}0,89_{(1)} \\
0,97_{(2)}\end{array}$ \\
\hline \multirow[b]{2}{*}{4} & $\begin{array}{l}\text { S/AD } \\
\text { KCl }\end{array}$ & & & & \\
\hline & $\begin{array}{c}\text { C/AD } \\
\text { KCl } \\
(\text { FI0,96) }\end{array}$ & $1,12_{(1)}$ & $0,87_{(1)}$ & $0,70_{(3)}$ & $0,54_{(3)}$ \\
\hline \multirow[b]{2}{*}{5} & $\begin{array}{c}\text { S/AD } \\
\text { KCl }\end{array}$ & $1,45_{(2)}$ & $0,66_{(2)}$ & $0,92_{(4)}$ & $0,55_{(4)}$ \\
\hline & $\begin{array}{c}\text { C/AD } \\
\text { KCl } \\
(\text { FI0,96) }\end{array}$ & $1,13_{(3)}$ & $0,82_{(3)}$ & $0,71_{(5)}$ & $0,51_{(5)}$ \\
\hline \multirow[b]{2}{*}{6} & $\begin{array}{l}\text { S/AD } \\
\text { KCl }\end{array}$ & $1,39_{(4)}$ & $1,50_{(4)}$ & $0,89_{(6)}$ & $0,97_{(6)}$ \\
\hline & $\begin{array}{c}\text { C/AD } \\
\text { KCl } \\
(\text { FI0,96) }\end{array}$ & $1,23_{(5)}$ & $1,10_{(5)}$ & $0,78_{(7)}$ & $0,70_{(7)}$ \\
\hline \multirow[b]{2}{*}{7} & $\begin{array}{c}\text { S/AD } \\
\text { KCl }\end{array}$ & $0,99_{(6)}$ & $0,70_{(6)}$ & $0,55_{(8)}$ & $0,55_{(8)}$ \\
\hline & $\begin{array}{c}\text { C/AD } \\
\text { KCl } \\
\text { (FI0,96) }\end{array}$ & $1,04_{(7)}$ & $0,63_{(7)}$ & $0,82_{(9)}$ & $0,63_{(9)}$ \\
\hline
\end{tabular}

Legenda:

COLUNA 2: S/AD KCl: SEM ADIÇÃO DE KCl; C/AD KCl: COM ADIÇÃO DE KCl. (FORÇA IÔNICA DE 0,96M).

COLUNA 3: Razão entre os valores das atividades observadas em $\mathrm{pH} 10,8$ e 8,33 . Cores: Amarelo forte: com adição de KCl. Amarelo claro: Sem adição de KCl. Rosa: Razão <1,0. Os números subescritos em parênteses correspondem às barras das Figuras 24 e 25 e resumem as condições experimentais.

COLUNA 4: Razão entre os valores das atividades medidas em $\mathrm{pH} 11,4$ e 8,33. Tonalidades de laranja forte:Razão<1,0. (Atividade maior em pH 8,33). Ocre e rosa: Razão $>1,0$

COLUNAS 5 E 6: Respectivamente análogas às colunas 3 e 4, com a diferença de que a razão é com o pH 9,33. Amarelo e laranja: Razão 10,8/9,33. Marrom claro e escuro: Razão 11,4/9,33. 
FIGURA 24: RAZÃO ENTRE AS ATIVIDADES EM pH 10,8 OU 11,4 E pH 8,33

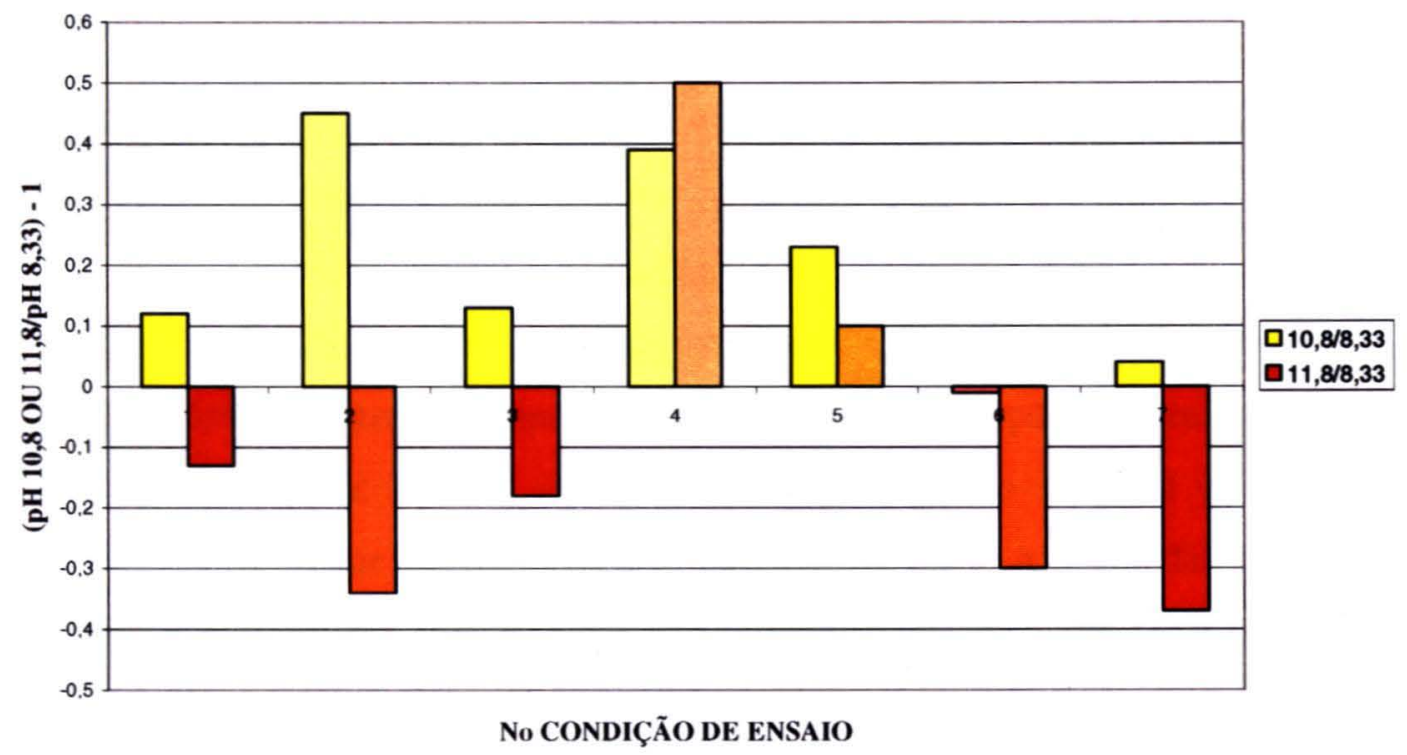

FIGURA 25: RAZÃO ENTRE AS ATIVIDADES EM pH 10,8 OU 11,4 E pH 9,33

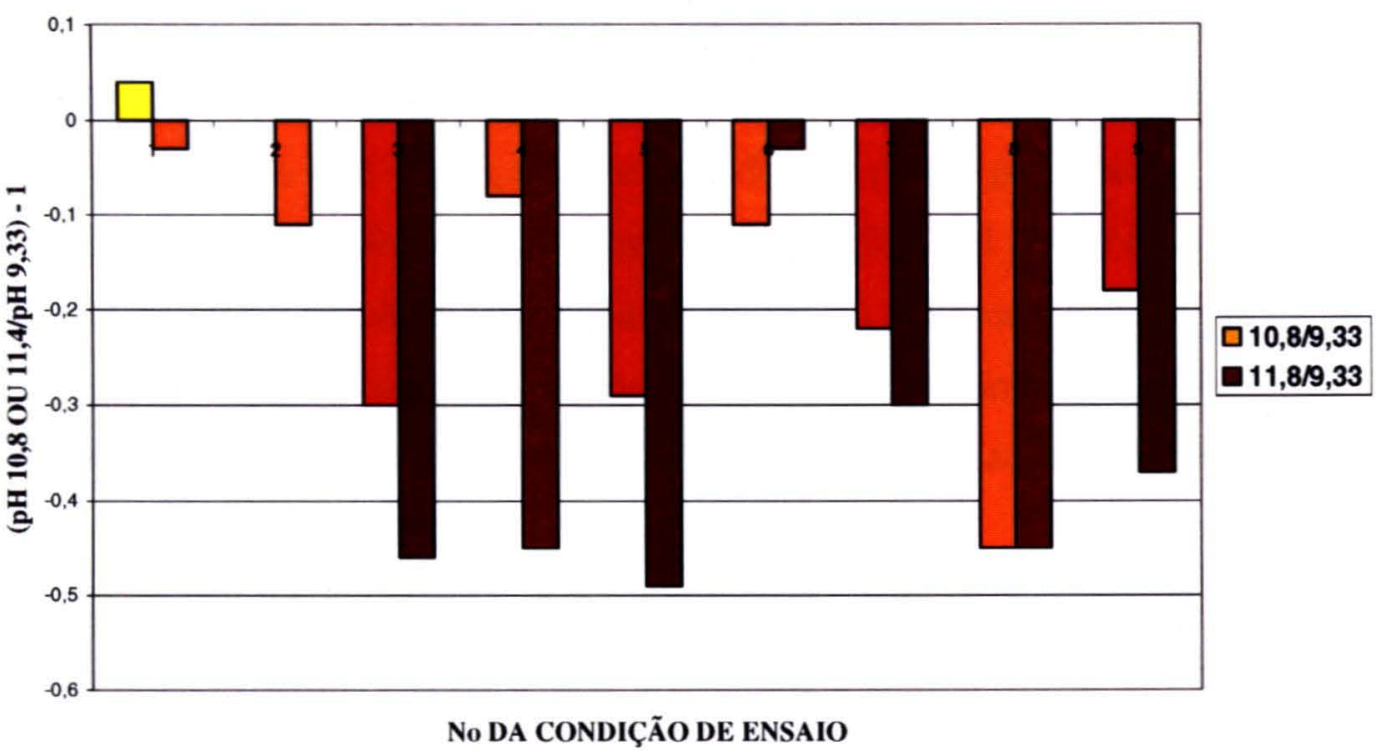

\section{Legenda:}

Abscissa: Condição de ensaio, correspondendo aos números subescritos em parênteses na Tabela 24. Os números das colunas 3 e 4, correspondem à Figura 24 e das colunas 5 e 6, à Figura 25.

Ordenada: Figura 24: (pH 10,8 ou 11,4/pH 8,33)-1

Figura 25: (pH 10,8 ou 11,4/pH 9,33)-1 


\section{DISCUSSÃo}

Dos vinte e um ensaios realizados, catorze apresentaram resultados indicando que a atividade da fosfatase alcalina de E.coli é maior na condição experimental CAPS 1M pH 11. TORRIANI, 1960 e GAREN e LEVINTHAL, 1960 descrevem o pH 8 ou 9 como sendo o pH ótimo da fosfatase alcalina de bactérias.

Dentre as 40 condições de ensaio utilizadas sem corrigir o valor do $\mathrm{pH}$ em função da diferença entre as temperaturas de preparo do tampão e de reação, assim como da força iônica, apenas seis apresentaram resultado no qual a atividade enzimática pH 11 do que aquela observada em pH 8 ou pH 9. A média da razão entre os valores obtidos em pH 11 e pH 8 foi de 2,06 (106\% maior em pH 11) e 1,98 (98\% maior em pH11) para a razão $\mathrm{pH} 11 / \mathrm{pH}$ 9. A razão média obtida entre o pH 11 e 8 nos ensaios realizados com a linhagem BS 7 foi de 1,78. O desvio-padrão da média foi de 0,15 , representando uma variação de $8 \%(1,78 \pm 0,15)$. Em relação ao tipo selvagem, a média foi de $1,94 \pm 0,22$, tendo uma variação de $12 \%$. Quanto à razão $\mathrm{pH}$ 11/9, a média foi de $1,82 \pm 0,16$, variando $9 \%$. A média para a linhagem BS 7 foi de $1,83 \pm 0,17$. Quando todos os dados são incluídos, não distinguindo as linhagens, a média passa a ser de $1,83 \pm 0,08$, apresentando $5 \%$ de desvio percentual.

Uma das condições na qual as razões pH (11/8) e pH (11/9) foram menores do que 1, ou seja, a atividade observada foi maior em $\mathrm{pH} 8$ ou $\mathrm{pH} 9$ do que em $\mathrm{pH}$ 11 , foi com o uso do tampão ácido bórico $\left(\mathrm{H}_{3} \mathrm{BO}_{3}\right)$, resultando em atividade $32 \%$ mais baixa neste $\mathrm{pH}$. No mesmo ensaio, o uso do tampão CAPS resultou em atividade 57\% maior em $\mathrm{pH} 11$.

O motivo da escolha do ácido bórico foi a tentativa de utilizar um único ampla faixa de $\mathrm{pH}$ variando de 8 a 13. Nesse ensaio (2), somente o pH 11 foi testado. Todas as isozimas da fosfatase alcalina de humanos são inibidas por íons fosfato, borato, oxalato e cianeto (TIEZ, 1986). Essa inibição poderia ser extensiva às fosfatases alcalinas de outras espécies, incluindo a E.coli.

No ensaio seguinte, a atividade observada nas reações efetuadas com tampões CAPS e ácido bórico, ambos na concentração de $0,5 \mathrm{M}$, foi $71 \%$ maior em pH $9 \mathrm{e}$ $32 \%$ pH 10, nas reações efetuadas com tampão ácido bórico. Portanto, não houve inibição da atividade enzimática. Em pH 12 e 13, nenhuma atividade enzimática foi 
detectada, possivelmente devido à perda da capacidade tamponante nessa faixa. De fato, posteriormente verificou-se que o $\mathrm{pK}_{\mathrm{a}}$ do borato é de aproximadamente 9,2.

No ensaio 8, a manutenção da suspensão celular em solução de SDS/clorofórmio pelo período de 2 semanas pode ter sido a causa da perda de atividade na linhagem BS 7, cultivada na presença de fosfato. Com o teste em FAST BLUE certificou-se a expressão da enzima, mas a perda de atividade somente na presença de $\mathrm{P}_{\mathrm{i}}$ pode ser justificada pelo contato do fosfato presente no meio por um tempo suficientemente longo, o que poderia ter inibido a atividade enzimática. TORRIANI (1960), realizou tratamento das células com mertiolate e tolueno e observou que a atividade enzimática não era alterada. De acordo com esses dados, é possível que o período de estocagem antes da realização do ensaio seja a principal causa da ausência de atividade. O ensaio 12, (condição experimental 17) e no ensaio 13, (condição experimental 19), a suspensão de bactérias também foi mantida em SDS clorofórmio. A manutenção de suspensão de bactérias em solução de preservação é uma alternativa para o adiamento do ensaio. Essa condição deve ser averiguada e testada com bastante rigor quando o objetivo do ensaio for a medida quantitativa. Seriam necessários experimentos adicionais para se verificar a reprodutibilidade da diminuição da atividade em pH 11 em relação ao pH 8 e 9, na presença de SDS-clorofórmio.

No ensaio 14, a razão entre o pH 11 e o pH 8 em reação efetuada com suspensões celulares obtidas de cultura em meio $A$ na presença de $1 \mathrm{mM} \mathrm{P}_{\mathrm{i}}$ foi de 0,71 e de 0,64 na razão $\mathrm{pH} 11 / \mathrm{pH} 9$. Uma das justificativas seria de que, apesar da expressão constitutiva da enzima, a presença de $P_{i}$ em concentração elevada pode por si só estar inibindo a atividade enzimática. Caso somente a interação enzima/fosfato estivesse determinando a variação na atividade, não seria observada qualquer atividade, independendo do $\mathrm{pH}$. Porém, a soma entre a presença de fosfato e a alta força iônica existente em $\mathrm{pH}$ elevado poderia contribuir na inibição da atividade enzimática observada em $\mathrm{pH} 11$.

O resultado da condição experimental 25 pode ter derivado da inadequação da concentração de $\mathrm{P}_{\mathrm{i}}$ no experimento. A bactéria E.coli do tipo selvagem foi cultivada em meio de cultura $\mathrm{A}$, na presença de $0,1 \mathrm{mM} \mathrm{P}_{\mathrm{i}}$. Esta concentração ainda é elevada demais para induzir a expressão da fosfatase alcalina em linhagens que expressam a 
enzima somente como resposta à carência de $\mathrm{P}_{\mathrm{i}}$, como o tipo selvagem (wt). É possível que a expressão da enzima não esteja sendo máxima devido à presença do fosfato no meio. Quando comparada à atividade da mesma linhagem cultivada em ausência de fosfato (linha azul da Figura 15). Comparando-se as duas curvas, nos valores de $\mathrm{pH} 8$ a 10, a atividade é 2,2 vezes menor na condição experimental na qual a linhagem do tipo selvagem foi cultivada em presença de $0,1 \mathrm{mM} \mathrm{P}_{\mathrm{i}}$. A diferença aumenta para 4,35 vezes quando somente os valores obtidos em pH 11 são comparados entre si. Contudo, isto não justifica o resultado, quando se comparam os valores de pH 11 e 8 ou 9 na mesma curva. Seriam necessários mais ensaios nas mesmas condições para a obtenção de número suficiente de dados que permitam fazer a análise estatística adequada. Na mesma linhagem cultivada em presença de fosfato $\left(1 \mathrm{mM} \mathrm{P}_{\mathrm{i}}\right)$, nenhuma atividade da fosfatase alcalina foi observada nos intervalos de $\mathrm{pH}$ avaliados, indicando a ausência da expressão proteica. O mesmo resultado foi obtido nos ensaios 17 e 18 .

Os tampões foram preparados considerando-se a diferença entre a temperatura de preparo da solução e a temperatura de reação, assim como a possível interferência da força iônica sobre a atividade enzimática.

Os ensaios de número 3 a 7 (Tabela 24) foram executados com a finalidade de verificar se os resultados seriam semelhantes àqueles advindos de ensaios realizados sem o ajuste de $\mathrm{pH}$ em função da temperatura e da força iônica.

Os resultados obtidos indicam que a razão entre o pH 10,8 e 8,33, independente da força iônica é em média $1,19 \pm 0,06$. Nesta condição experimental observou-se maior atividade em pH 10,8 do que em pH 8,33 ou 9,33. No ensaio 6, a razão entre o pH 11,4 e 8,33 foi maior do que 1, independendo da força iônica. As seguintes médias e os desvios-padrão foram calculados: razão entre pH 11,4 /8,33: $0,89 \pm 0,11$, razão entre $\mathrm{pH} 10,8 / 9,33=0,798 \pm 0,06$ e entre $\mathrm{pH} 11,4 / 9,33=0,73 \pm$ 0,08 .

Esses resultados refletem a importância na determinação da força iônica e da temperatura na escolha do tampão para a realização dos ensaios.

LOWRY(1957), em ensaio realizado com a fosfatase alcalina utilizando o $p$ nitrofenil fosfato o tampão 2-amino-2-metil-1-propanol $1 \mathrm{M}$ observou que a atividade 
enzimática neste tampão é aproximadamente o dobro daquela encontrada em tampão $0,1 \mathrm{M}$ glicina.

Nos ensaios realizados com tampão na concentração 0,5M CAPS não foram observadas atividades tão elevadas quanto em tampão $1 \mathrm{M}$.

De acordo com Lowry, na incubação realizada em pH 10 por 30 minutos, a fosfatase alcalina é lentamente degradada, alterando os resultados. Como nos ensaio realizados neste trabalho o tempo de incubação foi de 5 a 7 minutos provavelmente esta interferência pode ser descartada.

Ao se compararem os resultados, é importante observar que os ensaios acima foram realizados com a enzima purificada, cujo $\mathrm{pH}$ ótimo de atividade pode diferir de resultados obtidos em medidas realizadas com suspensões celulares.

Todas as isozimas da fosfatase alcalina são inibidas pelo fosfato, borato, oxalato e por íons cianeto, mas a atividade observada em ensaios realizados com tampão borato $0,5 \mathrm{M}$ foi em média $54 \%$ maior do que em CAPS $0,5 \mathrm{M}$, indicando que não houve inibição nesta concentração. Em pH 12 e 13, não se observou atividade.

Em pH 11,71 não se observa atividade enzimática porque provavelmente o CAPS perdeu a capacidade tamponante.

$\mathrm{O}$ aumento de $\mathrm{pH}$ é acompanhado pelo aumento da força iônica.Assim é importante fixar um valor de força iônica para se estudar o efeito do tampão sobre a atividade enzimática.

A maior atividade observada na linhagem rpo $S$ pode ser decorrente da quantidade de enzima expressa. 


\section{CONCLUSÕES:}

O objetivo de verificar a reprodutibilidade do resultado inicialmente obtido a partir de um único experimento no qual se observou aumento na atividade da fosfatase alcalina em tampão CAPS pH 11, foi alcançado.

A atividade observada em borato $0,5 \mathrm{M}$ é maior do que em CAPS, na mesma concentração.

Nos valores de $\mathrm{pH}$ estudados, a atividade foi maior em força iônica de $0,96 \mathrm{M}$.

Em pH 11,71, não se observa atividade enzimática por estar fora da capacidade tamponante do CAPS, cujo $\mathrm{pK}_{\mathrm{a}}$ é de 10,2. Em pH 12 e 13 (tampão borato $0,5 \mathrm{M})$, não se observa atividade enzimática provavelmente pelo mesmo motivo.

Ensaios realizados com bactérias cultivadas na presença de $\mathrm{P}_{\mathrm{i}}$ resultam em menor atividade, mesmo nas linhagens que expressam a enzima constitutivamente, indicando que a presença de $\mathrm{P}_{\mathrm{i}}$ ainda que residual possa estar inibindo pelo menos parcialmente a atividade enzimática. A concentração de $0,1 \mathrm{mM}$ não inibe totalmente a expressão da enzima na linhagem wt, mas a menor atividade indica menor quantidade de enzima. 


\section{CONSIDERAÇÕES FINAIS}

Os dados obtidos indicam um caminho a ser tomado na averiguação do uso potencial de uma enzima vastamente utilizada em Biologia Molecular (Sambrook e Russel, 2000), para uma finalidade completamente diferente. Esta seria a avaliação da qualidade da água de abastecimento através de procedimentos enzimáticos.

Os resultados obtidos poderão ser utilizados avaliando-os sob a luz dos conhecimentos acumulados acerca desta enzima e das técnicas emergentes.

Com o prosseguimento da pesquisa, novos resultados podem derivar a partir dos ensaios preliminares.

Outras condições experimentais específicas deverão ser testadas como por exemplo o uso do tampão piperidina, cujo pKa é de 11,12.

A atividade da fosfatase alcalina é maior na presença de alguns íons de metais divalentes, como por exemplo o cádmio. Esta característica poderia ser utilizada no desenvolvimento de biossensores para a detecção de áreas contaminadas por metais pesados.

Caso o aumento da atividade da fosfatase alcalina em $\mathrm{pH} 11$ seja restrito à E.coli, esta pode ser considerada uma situação de espécie-específica e o estudo estendido para a detecção de contaminação fecal.

Por outro lado, se o aumento da atividade em $\mathrm{pH} 11$ for resultante de um artefato experimental, ainda assim esta situação poderia ser utilizada no sentido de se aproveitar uma situação artificial para a detecção de microorganismos, na qual o aumento da intensidade da fosfatase alcalina funcionaria como um amplificador molecular. Bactérias em pequeno número, fragilizadas devido às condições inóspitas das estações de tratamento de água poderiam ser detectadas através dessa técnica.

A bactéria E.coli do tipo selvagem expressa a fosfatase alcalina em condições de carência do íon fosfato, ou seja, em concentração abaixo de $50 \mu \mathrm{M}$. (TORRIANI,1960). Em estações de tratamento de água, a concentração de fosfato é baixa o suficiente para induzir a expressão da enzima (EPA). Por outro lado, o meio é oligotrófico (APHA,1998) e poucos espécimes de cada espécie são encontrados nestas condições. Isto dificultaria a detecção da bactéria. 
As condições utilizadas no ensaio são muito distantes das condições fisiológicas, mas configuram uma situação experimental na qual se observou aumento da atividade enzimática.

Devido à existência de diversas variáveis atuando sobre a atividade enzimática, seriam necessários muitos experimentos nos quais cada variável fosse isolada e ensaiada de tal maneira que os resultados fossem estatisticamente significativos.

Testar outros tampões como a piperidina, de $\mathrm{pK}_{\mathrm{a}} 11,2$ e metilamina , $\mathrm{pK}_{\mathrm{a}} 10,6$, fixar e medir com precisão a força iônica das reações de ensaio, controlar o pH durante o ensaio, são algumas das medidas necessárias para que resultados mais precisos seja obtidos. 


\section{REFERÊNCIAS}

Amaral e Silva CC. Controle de Poluição do Meio (Poluição das Águas)

Disciplina HSA 5719, ministrada na Faculdade de Saúde Pública da Universidade de São Paulo. Notas de Aula [Aula 01-02/ago/2001].

American Public Health Association (APHA), American Water Works Association (AWWA) e Water Environment Federation (WEF) Standard Methods for the Examination of Water and Wastewater 20th ed. 1998

American Water Works Associaton (AWWA) Water Quality and Treatment - A Handbook of Community Water Supplies. $5^{\text {th }}$ Ed. NY: McGraw- Hill, INC.; 1999.

[Anonymus] Diálogo “Água para a Vida e para a Segurança”

http://www.barcelona2004.org/eng/banco del conocimiento/documentos/ficha.cfm? $\underline{\mathrm{IdDoc}=296}$ [2004 Out 16]

Ashbolt NJ, Grabow WOK, Snozzi M Indicators of microbial water quality. In: Fewtrell L, Bartram J, eds. Water Quality- Guidelines, Standards and Health: Assessment of Risk and Risk Management for Water- Related Infectious Disease. Aberystwyth and Geneva, Available at:

http://www.who.int/docstore/water sanitation health/Documents/IWA/iwabookchap $\underline{13 . h t m}$

Beynon, RJ e Easterby, JS Buffer Solutions The Basics. Oxford:Oxford University Press; 1996.

Brasil. Portaria ${ }^{\circ} 518$, de 25 de março de 2004. Estabelece os procedimentos e responsabilidades relativos ao controle e vigilância da qualidade da água para consumo humano e seu padrão de potabilidade, e dá outras providências. Diário Oficial da União; Poder Executivo, Brasília, 26 de março de 2004

Brasil. Lei nº 6.050 de 24-05-1974 :dispõe sobre a fluoretação da água em sistemas de abastecimento quando existir estação de tratamento.Diário Oficial da União; Poder Executivo, Brasília, 27 maio 1974.

Brasil. Portaria $n^{\circ}$ 635/BSB de 26 de dezembro de 1975: aprova normas e padrões, a seguir, sobre a fluoretação da água dos sistemas públicos de abastecimento, destinada ao consumo humano.Diário Oficial da União; Poder Executivo, Brasília, 30 de janeiro de 1976.

Brennan CA, Christianson K, La Fleur MA, Mandecki W. A molecular sensor system based on genetically engineered alkaline phosphatase.

Proc.Natl.Acad.Sci.USA. 1995; 92:5783-5787.

CESR (Center for Economic and Social Rights) On World Water Day (March 22), violations of Palestinians' human right to water escalating Available at: http://cesr.org/low/node/view/64 [2003 Mar 22] 
Clorosur. org Available at http://www.clorosur.org/?a=subcanal\&id=40\&can id=35 [2004 Ago 24]

Daar, A. Draft World Health Organisation guidelines on bioethics 1999

Available at: http://www.nature.com/wcs/b23a.html [2004 Fev 14]

Diálogo “Água para a Vida”

Available at:

http://www.barcelona2004.org/eng/banco del conocimiento/documentos/ficha.cfm? $\underline{\mathrm{IdDoc}=296}$ [2004 Out 12]

Dubai Declaration Calls for Global Strategy For Promotion of Science and Technology

Available at: http://www.ictp.trieste.it/twas/arch/DubaiDeclaration.html [2004 Jul 30]

EPA, 2005 Definição do termo poluição dado pela EPA

Available at: http://www.epa.gov/OCEPAterms/pterms.html [2004 Jun 15]

Fewtrell L, Bartram J. editors. Water Quality - Guidelines, Standards and Health: Assessment of Risk and Risk Management for Water-Related Infectious Disease. Geneva: World Health Organization 2004 Available at: http://www.who.int/docstore/water sanitation health/Documents/IWA/iwabookchap $\underline{13 . h t m \# 13.5}$ [2004 Dez 02]

Fórum Barcelona 2004 Available at http://www.barcelona2004.org/eng/forum2004.htm

Garen A, Levinthal C. A fine-structure genetic and chemical study of the enzyme alkaline phosphatase of E.coli. I. Purification and characterization of alkaline phosphatase_Biochim et Biophys Acta 1960; 38:470-483.

Hawkes, J Wooley, L History of mankind. Cultural and scientific development. vol. I

New York: Unesco; 1963.

Holtz KM, Kantrowitz ER The mechanism of the alkaline phosphatase reaction: insights from NMR, crystallography and site-specific mutagenesis.FEBS Lett.1999;462:7-11.

Hutchinson TH, Brown R, Brugger KE, Campbell PM, Holt M, Lange R, McCahon $P$, Tattersfield LJ, van Egmond R. Ecological risk assessment of endocrine disruptors. Environ Health Perspect. 2000 Nov;108(11):1007-14 
Lange, R Hengge-Aronis, R. Growth phase-regulated expression of bolA and morphology of stationary-phase Escherichia coli cells are controlled by the novel sigma factor sigma S. J. Bacteriol. 1991; 173(14):4474-4481.

Lowry OH Micromethods for the Assay of Enzymes Methods Enzymol.1957; 4: 36373

Mumford, L. Technics and Civilization. Harcourt, Brace and Co. New York, 1934.

Murphy A, Perrella J.A Further Look at Biotechnology. The Woodrow Wilson National Fellowship Foundation NJ, 1993.

Obst, U, Hübner, I, Wecker, M, Bitter-Suermann, D, 1989. Immunological method using monoclonal antibodies to detect Enterobacteriaceae in drinking water. Aqua $38,136-142$.

Organisation for Economic Co-operation and Development (OECD) Statistical Definition of Biotechnology, 2005.

Pivelli RP. Qualidade das águas.São Paulo; 1998.[Apostila do Curso de Pós Graduação - Faculdade de Saúde Pública da USP].

Pot DA, Woodford TA, Remboutsika E, Haun RS, Dixon JE. Cloning, bacterial expression, purification, and characterization of the cytoplasmic domain of rat LAR, a receptor-like protein tyrosine phosphatase J. Biol. Chem. 1991;266:19688-19696.

Rompré A, Servais P, Baudart, J, de-Roubin M-R e Laurent, P Detection and enumeration of coliforms in drinking water: current methods and emerging approaches. J. Microbiol. Methods. 2002; 49: 31-54.

Rosen G. Uma história da saúde pública.Trad.de M F S Moreira com a colab. de J R A Bonfim.São Paulo:Hucitec:Editora da Universidade Estadual Paulista; Rio de Janeiro: Associação Brasileira de Pós-Graduação em Saúde Coletiva; 1994.

Sabesp

Disponível em: http://www.sabesp.com.br/a_sabesp/historia/ontem.htm [2005 Mai 28]

Sambrook J e Russel D Molecular Cloning: A laboratory manual Cold Spring Harbor Laboratory Press; 2000.

Science and Environmental Health Network, Available at http://www.sehn.org/about.html [2003 Dez 16]

Secretaria da Saúde e do Meio Ambiente. Resolução Conjunta SS/SMA nº 1, de 26-897: dispõe sobre o teor mínimo de cloro residual livre na rede de abastecimento de água 
Schlesinger MJ, Olsen R. A New, Simple, Rapid Procedure for Purification of Escherichia coli Alkaline Phosphatase. Anal. Biochem. 1970; 36:86-90.

Singer, C, Holmyard, EJ Hall, AR. Water: supply, irrigation and agriculture. vol. I Cap 19. In: A History of Technology Clarendon Press, Oxford, 1956.

Soares, B.E.C.; Navarro, M. A.; Ferreira, A. P. (2004). Desenvolvimento Sustentado e Consciência Ambiental: Natureza, Sociedade e Racionalidade. Ciências \& Cognição; Ano 1, Vol 02. Disponível em http://www.cienciasecognicao.org Stinson, RA Best buffer for Routine alkaline phosphatase assays. Clin. Chem. 1991; 37(1):134-135.

Spira, B. Studies on the control of the PHO regulon and the phosphatase specific transport (Pst) system in E.coli Tel-Aviv; 1996.[Tese de Doutorado apresentada no Instituto Weismann].

Stryer L. Biochemistry. $3^{\text {rd }}$ Ed. New York:W.H.Freeman \& Co., 1988.

Torriani A. Influence of inorganic phosphate in the formation of phosphatases by Escherichia coli_Biochim. Biophys. Acta. 1960; 38: 447-460

Unicef e WHO (World Health Organization/ Organização Mundial da Saúde) Meeting the MDG Drinking Water and Sanitation Target- A Mid-Term Assessment of Progress agosto 2004 Available at http://www.unicef.org/wes/mdgreport/ [2004 Ago 3]

Unicef. Newsline Bad water kills 4,000 children a day Aug 2004 Available at http:www.unicef.org/wes/index_23249.html [2004 Ago 25]

United Nations, General Assembly Dec 10, 1948. Universal Declaration of Human Rights Available at http://www.un.org/Overview/rights.html [2002 Out 21]

United Nations, Report of the United Nations Conference on the Human Environment, Estocolmo, Junho 1972 Available at http://www.unep.org/Documents/Default.asp?DocumentID=97 [2002 Out 21]

United Nations, Agenda 21, the Rio Declaration on Environment and Development, the Statement of Forest Principles, the United Nations Framework Convention on Climate Change and the United Nations Convention on Biological Diversity, Rio de Janeiro, Junho 1992.

United Nations, Draft report of the Summit World Summit on Sustainable Development Johannesburg Summit 2002 (Rio +10) Johannesburg, Agosto 2002 Available at http://www.un.org/jsummit/html/documents/summit docs.html [2004 Jun 15] 
United States of America, 1974 United States Code Title 42-The public health and welfare Chapter 6A- Public Health Service Chapter XII-Safety of Public Water Systems (Safe Drinking Water Act) Available at http://www.access.gpo.gov/uscode/title42/chapter6a subchapterxii.html

United States Code, 1977. Amendment of the Federal Water Pollution Control Act (Clean Water Act) Available at http://www.epa.gov/region5/water/cwa.htm [2003 Dez 16]

U.S. Department of Energy, Office of Science, Office of Biological and Environmental Research Microbial Genome Program Available at: <URL:http://www.sc.doe.gov/production/ober/microbial.html> [2004 Out 14]

U.S. Department of the Interior, U.S. Geological Survey Toxic Substances Hydrology Program. Available at:

< URL:http://toxics.usgs.gov/regional/emc/index.html> [2004 Mar 23]

U.S. Environmental Protection Agency (USEPA or EPA) Terms of Environment Available at:<URL: http://www.epa.gov/OCEPAterms/> [2004 Jul 16]

Watson JD e Crick F General implications of the structure of deoxyribonucleic acid. Nature 1953; 171: 964-967.

White TJ, Arnheim N, Erlich HA The polymerase chain reaction. Trends Genet. $1989 ; 5(6): 185-189$.

WHO (World Health Organization) http://www.who.int/water sanitation health/dwq/2edvollb.pdf

Xiao H, Kalman M, Ikehara K, Zemel S, Glaser G, Cashel M. Residual guanosine 3',5'-bispyrophosphate synthetic activity of relA null mutants can be eliminated by spoT null mutations. J Biol Chem 1991; 266(9):5980-90 